\title{
Reverse Logistics Network Design in Circular Economy Promoting Sustainable Collection and Reuse for Post-consumer Textile and Clothing
}

\author{
By \\ Mohammad Abdullatif Bukhari
}

Submitted to the Department of Industrial Engineering, Business Administration and Statistics in partial fulfilment of the requirements for the degree of

Doctor by Universidad Politécnica de Madrid (UPM)

At the

ESCUELA TÉCNICA SUPERIOR DE INGENIEROS INDUSTRIALES

UNIVERSIDAD POLITÉCNICA DE MADRID

May 2018

Signature of Author

Mohammad Abdullatif Bukhari

Accepted by

Dr. Ruth Carrasco-Gallego

Associate Professor.

Universidad Politécnica de Madrid

Accepted by

Dr. Eva Ponce-Cueto

Associate Professor.

Massachusetts Institute of Technology 


This thesis is subject to the following creative commons license:

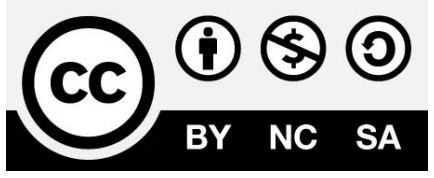

Mohammad Abdullatif Bukhari

Escuela Técnica Superior de Ingenieros Industriales

Universidad Politécnica de Madrid 2018 
Titulo:

Reverse Logistics Network Design in Circular Economy. Promoting Sustainable Collection and Reuse for Post-consumer Textile and Clothing

Autor: Mohammad Abdullatif Bukhari

Tribunal Membrado por el Magfco. Y Excmo. Sr. Rector de la Universidad Politécnica de Madrid, el día ... de ... de 2018.

Presidente:

Secretario:

Vocal:

Vocal:

Vocal:

Suplente:

Suplente:

Realizado el acto de defensa y lectura de la tesis el día ... de ...... de 2018 en la Escuela Técnica Superior de Ingenieros Industriales de la Universidad Politécnica de Madrid.

El Presidente El Secretario

\section{Los Vocales}


I am grateful to God "Allah" who has given me the courage to conduct my Ph.D. studies and facilitated the process by blessing me with encouraging parents, supporting siblings, and a great and patient companion - my wife

To you I send my love and gratitude. 
The author intends to publish all the results of this Ph.D. study.

Publications resulting from this thesis, so far:

Bukhari, M.A., Carrasco-Gallego, R. and Ponce-Cueto, E. (2018),

“Developing a national programme for textiles and clothing recovery", Waste Management \& Research, Vol. 36 No. 4, pp. 321-331. 
The author had a scholarship for doing this Ph.D. research and has been funded by the Ministry of Education of Saudi Arabia from September 2014 until June 2018. 


\section{Abstract}

This doctoral thesis has been framed to contribute to the evolving fields of reverse logistics, sustainable development and circular economy. It focuses on the sustainability of post-consumer textile recovery management. The recovery of used textile and garments has been receiving more and more attention from researchers, professionals and legislators, due to the social, economic and environmental benefits behind it. The "fast fashion" industry faces severe challenges to overcome the need for social and environmental sustainability along the entire product lifecycle. The increasing trend of waste generation, resulted from the rapid increase of population and the irresponsible production and consumption of materials and products among producers and consumers, has forced policy makers in many developed countries to regard the waste recovery and management among the top issues that need to be addressed in their agendas. This study addresses the recovery of post-consumer textile and clothing aiming to provide valuable insights and recommendations to improve the current textile collection and recycling in a sustainable manner. It provides original findings that benefit both academic and practical domains.

Textile waste is relatively small in terms of weight as compared to other waste streams, but it has a large impact on human health and environment, and its rate is increasing due to the "fast fashion" model. Previous studies on textile recovery management are limited, which prevent our scope from improving current practices in this sector. This study examines the recovery of post-consumer textile and clothing in both France and Germany identifying similarities and differences in the practices of recovering used textile and clothing. To date, France is the only country in the world implementing Extended Producer Responsibility (EPR) policy for end-of-use clothing, linen and shoes. The case highlights the benefits of using EPR policy and provides interesting insights about the challenges faced by the textile waste sector. For instance, the EPR policy has contributed to the increase of the collection and recycling of post-consumer textile since 2006. More specifically, the amount of textile collected now in France is three times more than the amount collected before enforcing the policy. The material recovery rate of the post-consumer textile has proven a high recovery rate $(90 \%), 50 \%$ of which can be directly reused. However, the research shows that both France and Germany export a large amount of the recovered textile to Africa for "re-use" and many African countries are considering banning the used textile import to encourage a competitive textile industry locally and internationally. The EPR policy demonstrates a great potential to identify other markets for "re-use" to increase the demand for the collected textile by supporting innovation and new product development. It can thus be regarded as a legal instrument that drives societies to maintain sustainable finance for supporting technological innovation and research development to support fashion producers for 
adopting eco-design and design for recycling practices as well as improving the processes for closing the material loop. In our discussion, we propose improving the EPR policy to allow for achieving higher productivity and carbon emission saving.

The adoption of linear programming method to examine the current textile recovery practices in France has revealed potential savings of transportation cost and greenhouse gas (GHG) emissions. In the quantitative case study in chapter five, transportation cost and GHG emissions of textile collection in Paris have been analyzed using a simple linear programming (LP) model. The study shows that by collectively managing the textile collection and recycling, societies can cut $70 \%$ of both transportation cost and carbon emissions. Thus, a mixed integer linear programming (MILP) model has been proposed in chapter five to provide textile recycling managers with the decision-making tool to optimize their reverse logistics networks to reduce their logistics costs and GHG emissions.

The dissertation highlights the need for better measures and policies for improving the current collection and reuse of textile and clothing in Europe, while addressing critical sustainability issues that need to be considered for the circular economy (chapter 6). The circular economy transition advocated by the European Union focuses primarily on material recovery aiming for improving economic, social, and environmental development, throughout the member states. However, the circular economy policies do not address the sustainability of the current supply chain networks from a global perspective and only collaterally intends to approach the sustainable development goal of realizing sustainable production and consumption. Despite the current focus of the new Circular Economy Package to increase the material collection and recycling targets, the objective of reusing these materials within the European economy, to reduce importing similar products and materials, is hardly addressed. This dissertation discusses some of the metrics required for circular economy transition and contributes to the understanding and knowledge on circular economy and resource efficiency by providing valuable insights on sustainability issues in the fashion industry. 


\section{Resumen}

Esta tesis doctoral se enmarca en el ámbito de la logística inversa, el desarrollo sostenible y la economía circular. Se centra en la sostenibilidad de la gestión en la recuperación del textil postconsumo. La recuperación de textiles y prendas de vestir usadas recibe cada vez más atención de parte de investigadores, profesionales y legisladores, debido a los beneficios sociales, económicos y ambientales que la respaldan. La industria de la "moda rápida" tiene que hacer frente a importantes retos desde el punto de vista de la sostenibilidad social y ambiental a lo largo de todo el ciclo de vida del producto. La generación de residuos presenta una tendencia creciente, como resultado del rápido aumento de la población y del crecimiento (irresponsable) en la producción y el consumo de materiales y productos en fabricantes y consumidores. Esto ha obligado a muchos países desarrollados a considerar la recuperación y gestión de residuos entre los principales problemas que deben abordar en sus agendas. Este estudio se centra en la recuperación de textiles y prendas de vestir postconsumo con el objetivo de proporcionar información valiosa y recomendaciones para mejorar la recogida y el reciclaje textil de forma sostenible. Proporciona hallazgos originales que contribuyen tanto al ámbito académico y profesional.

Los residuos textiles son relativamente más ligeros en comparación con otras fuentes de desechos, pero tienen un gran impacto en la salud humana y el medio ambiente, y su volumen está aumentando debido al modelo basado en la "moda rápida". No existen muchos estudios que investiguen la recuperación de residuos en sector textil, lo que impide mejorar las prácticas actuales en esta industria. Este estudio examina la recuperación de textil y prendas de vestir usadas en Francia y Alemania, identificando similitudes y diferencias en las prácticas de ambos países. Hasta la fecha, Francia es el único país del mundo que ha implementado la política de Responsabilidad Ampliada del Productor (RAP; EPR, por sus siglas en inglés) para ropa, ropa de cama y calzado de final de uso. El caso destaca los beneficios del uso de la política de RAP y proporciona información interesante sobre los retos a los que actualmente se enfrenta el sector textil. Por ejemplo, la política RAP ha contribuido a un aumento en las tasas de recogida y reciclaje de los textiles postconsumo desde 2006, en concreto, la tasa de recogida se ha multiplicado por tres. Además, la tasa de recuperación de materiales en los textiles usados puede alcanzar el 90\%, 50\% de los cuales puede ser directamente reutilizado. Sin embargo, la investigación muestra que tanto Francia como Alemania exportan una gran cantidad del textil recuperado a África para su "reutilización" y muchos países africanos están considerando prohibir la importación de textil usado para alentar a una industria textil competitiva a nivel local e internacional. La política de RAP muestra un gran potencial para identificar otros mercados para la "reutilización" y para mejorar el cierre del bucle en el sector textil a la vez que apoya la innovación y el desarrollo de nuevos 
productos. Por lo tanto, la política de RAP puede considerarse un instrumento legal que impulsa a los productores de moda a apoyar financieramente la innovación y la investigación para proporcionar soluciones viables que adopten diseño ecológico y procesos orientados al reciclado y/o al cierre del bucle. En esta tesis se propone una extensión a la política de RAP que permita lograr una mayor productividad y ahorro de emisiones de gases de efecto invernadero (GEI).

La adopción de un modelo de programación lineal para examinar las prácticas actuales de recuperación textil en Francia ha revelado un ahorro potencial de los costes de transporte y las emisiones de GEI. En el estudio de caso cuantitativo presentado en el capítulo cinco, se aplica este modelo a la recogida de textil en París y el estudio muestra que al gestionar de manera colectiva la logística inversa del textil, se puede reducir en un $70 \%$ el coste de transporte y las emisiones de GEI. Por lo tanto, en el capítulo cinco se ha propuesto un modelo de programación mixta-entera para proporcionarles a los gerentes de reciclaje de textiles la herramienta de toma de decisiones para optimizar sus redes de logística inversa para reducir sus costes de transporte y emisiones de GEI.

Esta tesis doctoral destaca la necesidad de identificar nuevas medidas y prácticas para mejorar la recogida y la reutilización de textiles y prendas de vestir usadas en Europa, abordando cuestiones críticas de sostenibilidad que deben tenerse en cuenta para la economía circular (capítulo 6). La transición a la economía circular propugnada desde la Unión Europea se centra en la recuperación de materiales con el fin de mejorar el desarrollo económico, social y ambiental en los países miembros. Sin embargo, estas políticas no abordan la sostenibilidad de las redes de suministro actuales desde una perspectiva global y solo se acercan de forma colateral al objetivo de producción y consumo sostenibles. A pesar del enfoque actual del paquete de Economía Circular de aumentar los objetivos de recogida y reciclaje de materiales, apenas se aborda el objetivo de reutilizar estos materiales dentro de la economía europea, con el fin de reducir la importación de productos y materiales similares. Esta tesis discute algunas de las métricas requeridas para la transición de la economía circular y contribuye a un mayor conocimiento sobre la promoción de la economía circular y la eficiencia de los recursos al proporcionar información valiosa sobre cuestiones de sostenibilidad en la industria de la moda. 


\section{Table of Contents}

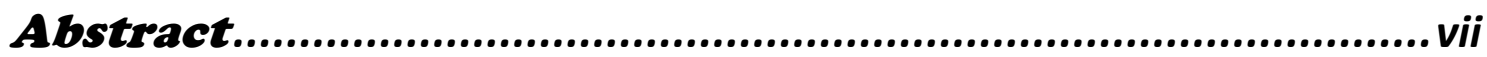

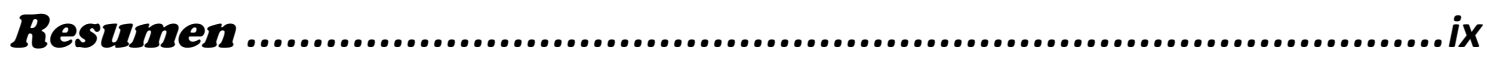

List of Figures .............................................................................

List of Tables ...........................................................................

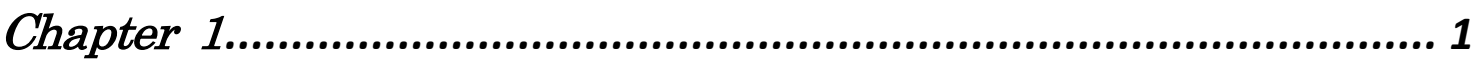

INTRODUCTION..........................................................................................

1.1 Research Background ...................................................................................1

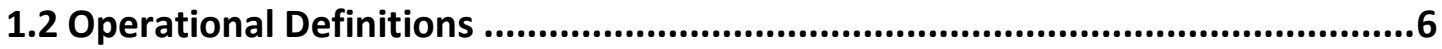

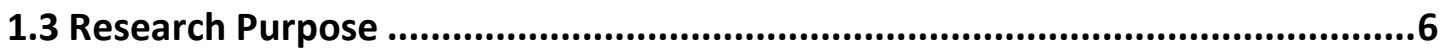

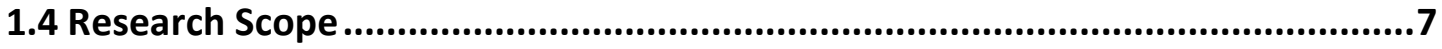

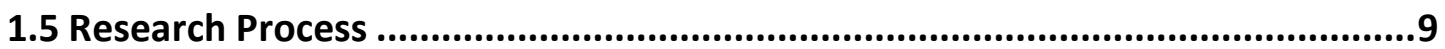

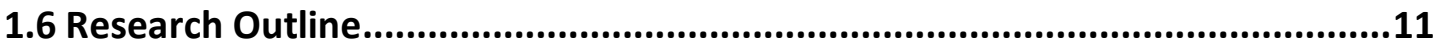

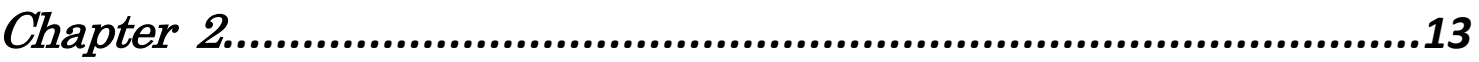

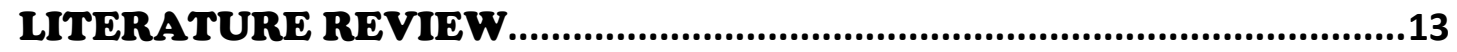

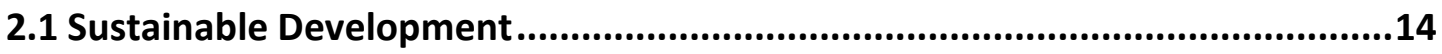

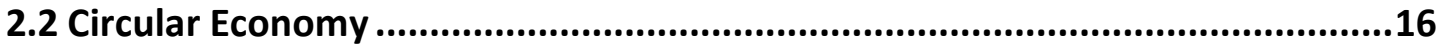

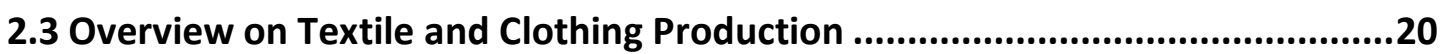

2.4 Sustainability in the Fashion Industry..............................................................24

2.5 Waste Management Policies in Europe .........................................................33

2.6 Extended Producer Responsibility ...................................................................36

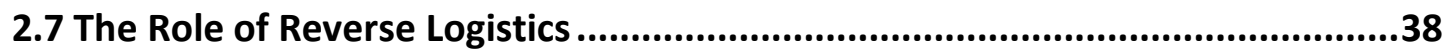

2.8 Drivers and barriers for implementing reverse logistics .................................42 


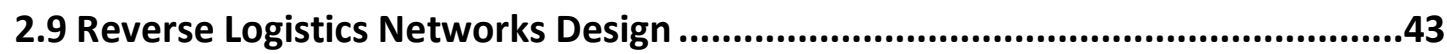

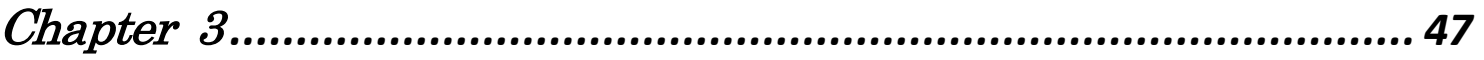

OBJECTIVES AND RESEARCH METHODOLOGY ............................47

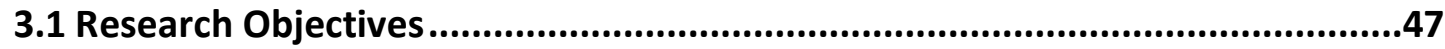

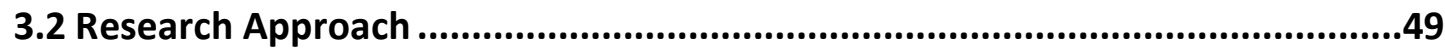

3.3 Research Methodologies in Operations Management......................................51

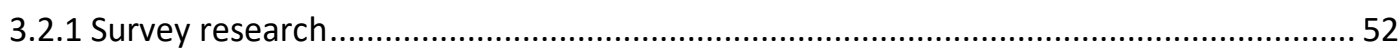

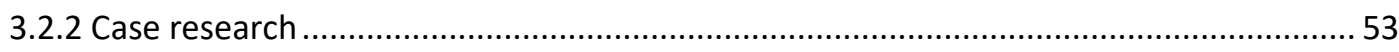

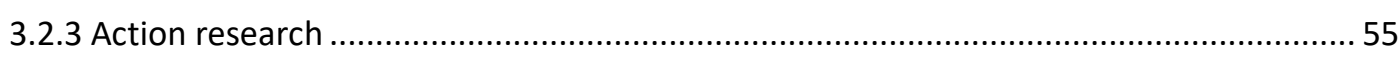

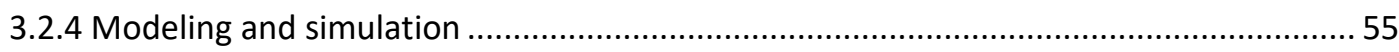

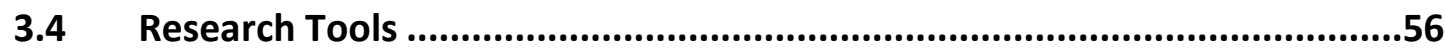

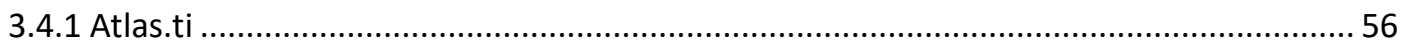

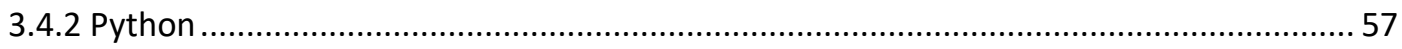

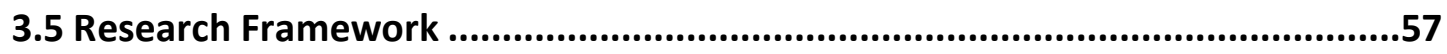

Chapter 4 ......................................................................... 61

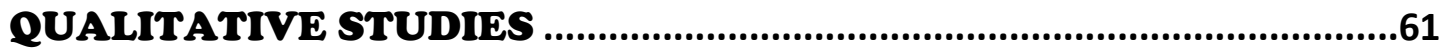

4.1 Post-Consumer Textile Recovery in France ......................................................61

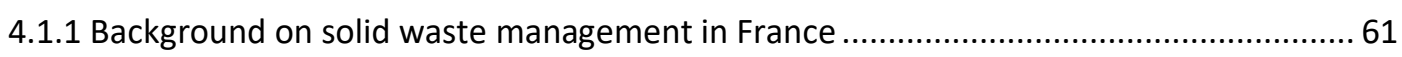

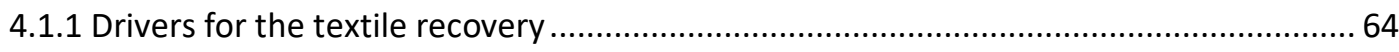

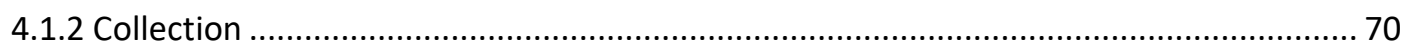

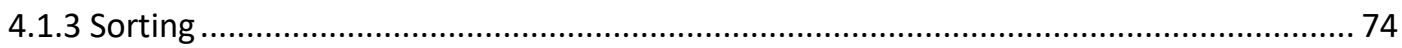

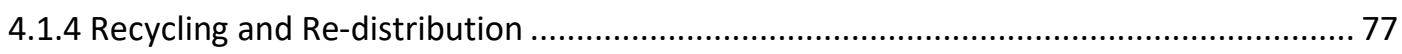

4.2 Post-Consumer Textile Recovery in Germany ...................................................78

4.2.1 Background on solid waste management in Germany ................................................. 78

4.2.2 Perception of German consumers on used textile and clothing.................................... 82

4.3 SOEX Group: Collection and recycling of post-consumer textile and clothing ..83

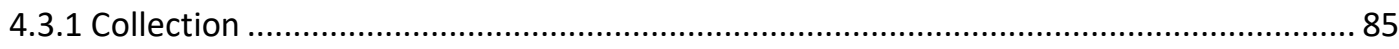

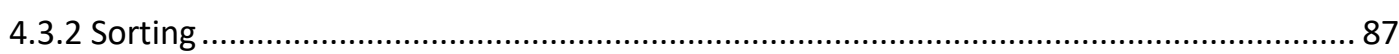

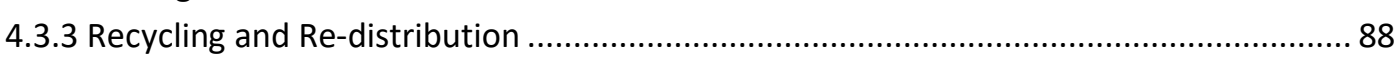

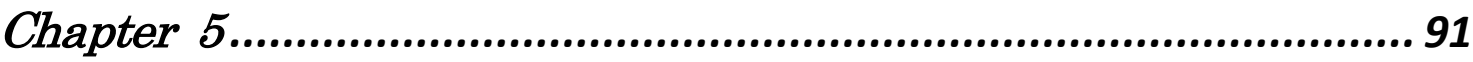

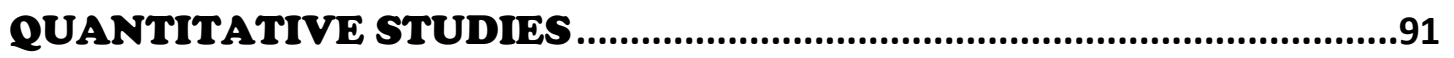


5.1 Linear Programming Model for Textile Recovery .......................................92

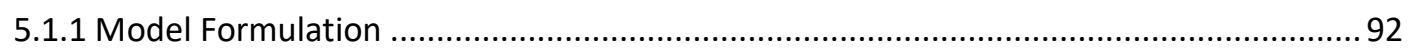

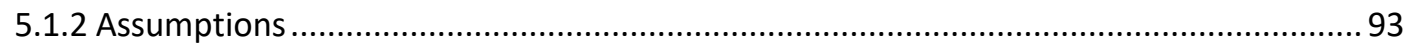

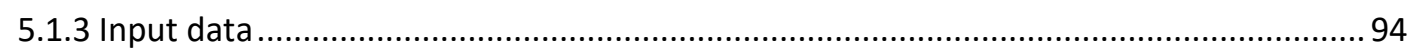

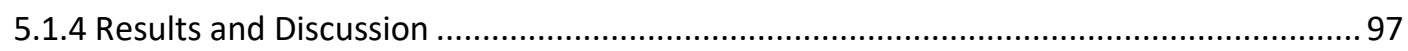

5.2 Mixed Integer Linear Programming Model for Textile Recovery ....................100

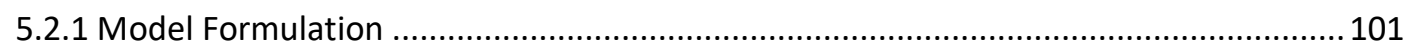

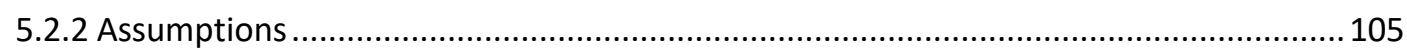

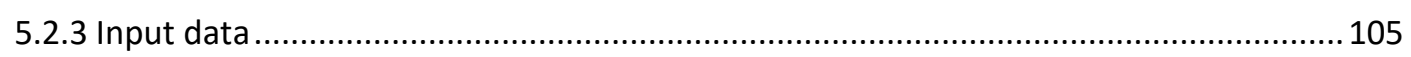

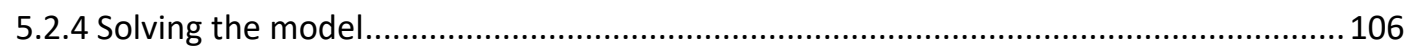

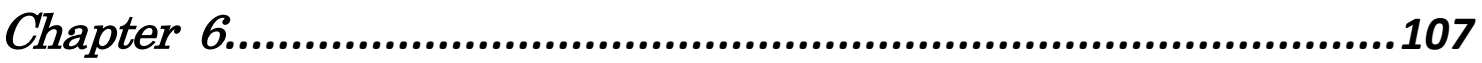

ORIGINAL CONTRIBUTION AND FUTURE RESEARCH.................107

6.1 Textile Collection and Recycling Channels in France and Germany .................107

6.2 Current challenges in the current textile and clothing recovery......................109

6.2.1 Challenges for used textile reuse .............................................................................. 109

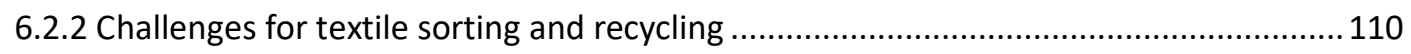

6.3. The benefits of the EPR policy for textiles and clothing ............................................... 111

6.4 Circular economy: scope and limitations ...................................................116

6.5 Circular Economy: towards a sustainable material recovery ..........................120

6.5.1 Promoting traceability and effective data management ...........................................120

6.5.2 Setting up the circular economy for material reuse and recycling ................................ 121

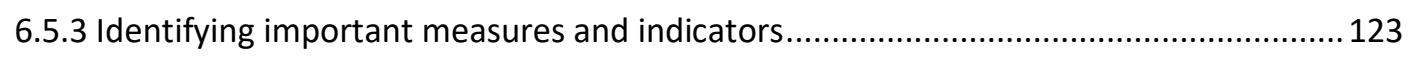

6.6 Research Delimitations and Future Opportunities .........................................126

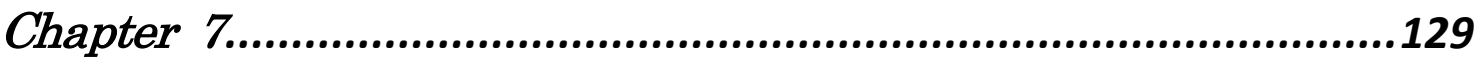

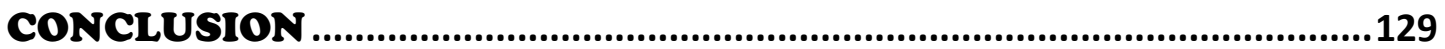

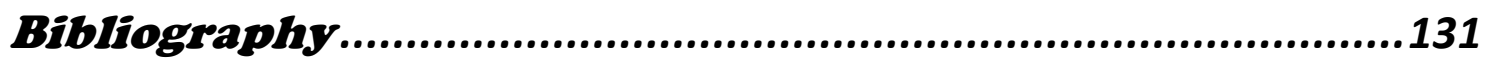

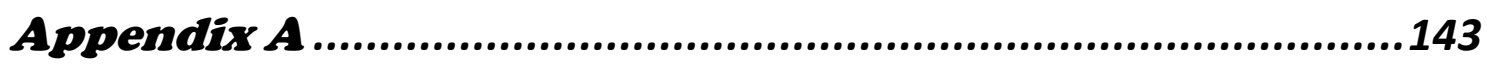

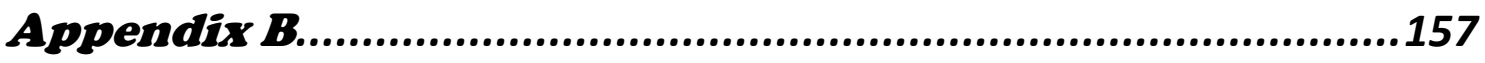





\section{List of Figures}

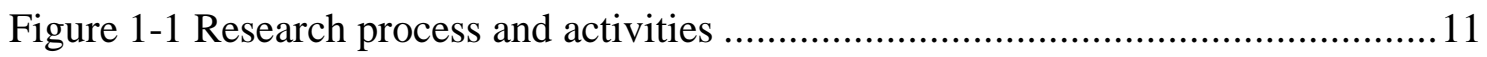

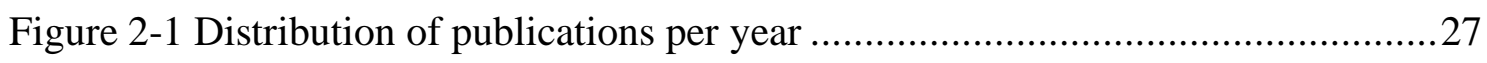

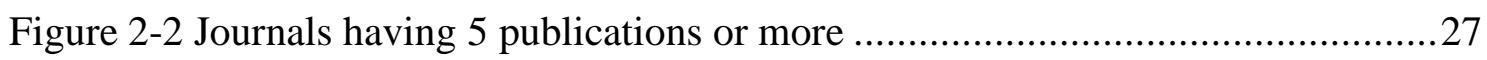

Figure 2-3 Number of published papers different areas in the value chain ..................28

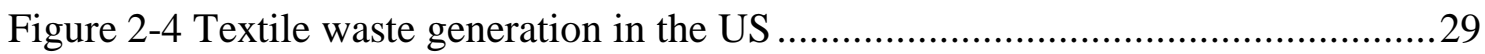

Figure 2-5 Estimation for the annual amounts of landfilled textile in different countries

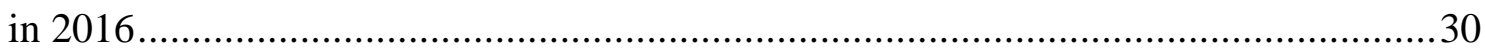

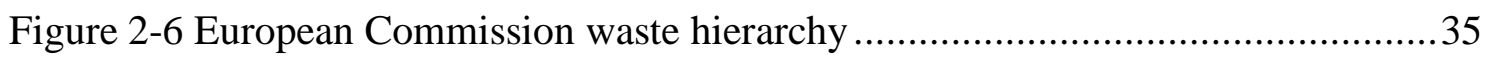

Figure 2-7 Generic form of Closed Loop Supply Chain ......................................... 41

Figure 4-1 EPR policy for textile, shoes \& linen in France ....................................65

Figure 4-2 Stakeholders acting in the French textile recovery system ........................70

Figure 4-3 Annual increase in collection of textile and clothing in France ..................72

Figure 4-4 Number of collection points in France.................................................... 73

Figure 4-5 Municipal solid waste treatment (in \%) in selected EU countries...............79

Figure 4-6 Authorization for textile collection in Germany......................................... 82

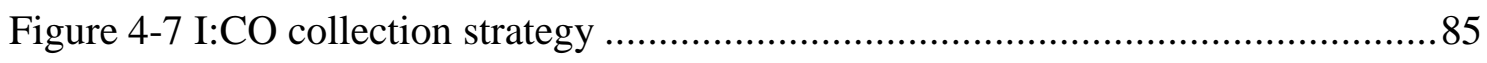

Figure 4-8 SOEX group collection schemes ................................................... 86

Figure 4-9 SOEX collection and recovery channels for used clothing ........................89

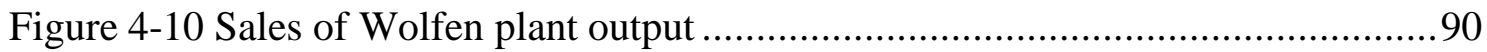

Figure 5-1 Representation for collection points distributed in Paris, France .................95

Figure 5-2 Collection channels of used textile from Paris, France .............................96

Figure 5-3 Projection of transportation cost for collecting used textile from Paris,

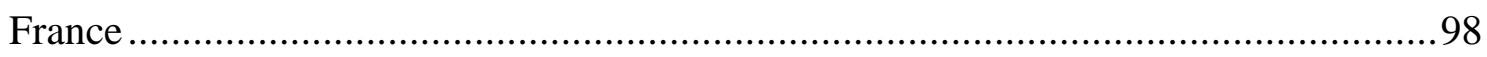

Figure 5-4 Projection of $\mathrm{CO}_{2}$ emission for collecting used textile from Paris, France...98

Figure 6-1 Channels of recovering used textile and clothing in France and Germany. 109 
Figure 6-2 Potential stages for promoting sustainable production and consumption of

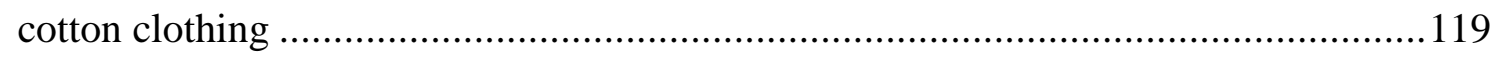

Figure 6-3 Material flows between two economies from resource inputs and imports to

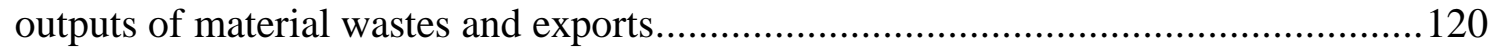

Figure 6-4 Circular economy vault for securing circular industry globally................122

Figure 6-5 The roles of the PRO for recovering textile and clothing .......................123 


\section{List of Tables}

Table 2.1 Number of times specialty apparel retailers has been mentioned as a fast fashion in media publications

Table 4.1 Tariffs for 2016 members' contribution (n-1=2016)..... 68

Table 4.2 Collection channels implemented in France and their performance 74

Table 4.3 Sorting and recycling performance required for receiving financial support from Eco TLC.

Table 4.4 Sorting agencies qualifications for receiving financial support from Eco TLC

Table 4.5 The share of unraveling and cutting processes and their market locations in 2013

Table 4.6 The share of each category and its market location from the total textile collected in 2013 .

Table 4.7 Textile collection and recycling in Germany in 2007 and 2013 ...................83

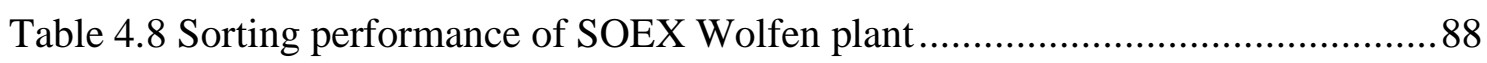

Table 5.1 Location and holders of used textile collected in Paris ..............................95

Table 5.2 Estimation of transportation cost and emission for different truck-load destinations .97

Table 6.1 Proposed waste management targets 118

Table 6.2 Data required for measuring the circular performance... 125

Table 6.3 Proposed measures for annual evaluation. 126 



\section{Chapter 1}

\section{INTRODUCTION}

In the last few decades, the concept of Reverse Logistics (RL) has been widely acknowledged and increasingly implemented for products and materials reclamations in several industries. The Reverse Logistics approach can provide a sustainable opportunity for promoting environmental benefits for societies and organizations. This is because it helps planning and managing the flow of materials efficiently and stimulating logistics cost and carbon emissions savings, while preventing natural resources from depletion and landfilling. The concept has some relative implications that help to realize sustainable development and material efficiency.

\subsection{Research Background}

The study of supply chain (SC) and operations management (OM) has played a critical role in the industrial evolution. With its integrative and interdisciplinary character, supply chain management (SCM) has not only become the backbone of the firm's activities, rather, to our economy. Nowadays, managing the supply chain requires a clear understanding and vision for dealing with the materials 
along the forward supply chain processes (source-produce-distribute) and the reverse supply chain (collect-recover-reuse) after end-of-use. Managing the reverse physical flow of the supply chain - so called Reverse Logistics - aims to provide economic, environmental and social benefits to the firms as well as to the society. This is especially when firms and societies adopt a long-term strategic approach to efficiently design their logistics networks to reduce the sustainability burdens of material collection, re-use, re-cycling, re-manufacturing and disposal of the products we use. This study identifies off-stage burdens observed through the current practices of collection, reuse, and recycling of post-consumer textile and clothing.

The textile and clothing sector plays a fundamental role in our economy, society and environment. The industry is one of the largest sectors in terms of investment, revenue, trades, and employment generation. In 2016, the overall size of the economy of the textile and clothing sector in the EU-28 attained a turnover of $€ 171$ billion and investments of $€ 4.8$ billion (EURATEX, 2017). The global apparel market is valued approximately $€ 2.4$ trillion (US\$3 trillion) employing approximately 60 million workers in 2014 (FashionUnited, 2016). According to the figures published by the British Fashion Council, the fashion industry contributes in approximately $€ 33$ billion (£29.7) to the UK GDP and it is estimated to support around 850 thousand jobs in 2016 (British Fashion Council, 2018). Today, global annual textile consumption is about 62 million tons and has 


\section{Introduction}

been projected to rise by $63 \%$ in 2030 to reach 102 million tons (Global Fashion Agenda \& The Boston Consulting Group, 2017). From the growing consumption of textile and clothing, the industry has a great potential to turn the textile waste into a valuable source of material. Thus, efficient reverse logistics to recover textile waste would help societies to promote circular economy. The European Commission has recently adopted a circular economy package and published an action plan to guide the member states towards a circular transition. This would require independent societies to pay a great attention on the re-use, recycling and closing the loop of the materials to create social and economic opportunities as well as improving the environment. As a result, member states should follow a clear strategy that helps them to reduce the wastes and to achieve the specific targets attached to the EU waste legislation, Directive 2008/98/EC.

Preventive principles to solving environmental issues has been adopted as environmentally and economically valuable for several decades. The general interest was limited throughout the 1970's and 1980's; however, it has grown notably over the past decade. The effort of the United Nations Environment Program (UNEP), and many other international, national and local actors, in the Cleaner Production Program has gradually changed businesses, organizations and societies to become more sustainability-oriented for approaching environmental problems. There were different preventive attempts in the 1970's and 1980's to solve solid waste management problems and large-scale 


\section{Chapter 1}

mechanical sorting centers for mixed household waste that had been practiced in several countries across the globe. However, the technology used was largely disappointing as it generated materials that had not been demanded by the available markets. Subsequently, source separation recycling has appeared to have a potential solution for this problem. Recycling based on source separation proved to supply the markets with the requested materials but the revenues for selling these materials can barely cover the cost for source separation activities. Collection had to be subsidized using different tax instruments to be applied on businesses and/or households. The 1970's and 1980's also witnessed several attempts from governments in several industrialized countries to drive producers by enacting new legislation or voluntary agreements to promote the use of refillable containers instead of one-way beverage containers. Currently, different practices of clothing recovery have proved environmental, social, and economic benefits and great attention is observed to encourage sustainable development in the textile industry.

In the late $20^{\text {th }}$ century, the industrial and technological revolution of the fashion industry has led to establishing more factories over-producing wearable fabrics. The mass production of clothing led to a rapid reduction in sales price and drove up a new clothing buying habit for customers. The competition of the low-cost apparel production led to employing unqualified personal hired with a low wage. The ease of producing cheap colorful fabrics led producers to use 


\section{Introduction}

improper and toxic materials to increase the production efficiency. As a result, low quality, harmful, and toxic garments were produced and imported to developed countries. To control the quality of clothing and ensure healthy products and environment for the employees and society, series of regulations and standards have been raised by policy makers to lead fashion retailers to move their factories to less strict countries in terms of the laws concerned on quality standard, working environment, and employees' wages. As a result, the price of producing and selling fashion products has declined rapidly leading large retailers to adopt fast fashion-based models characterized by mass production, variety, agility and affordability to push consumers behavior towards buying new clothing. According to Pedersen and Andersen (2013), fast fashion created demand for 80 billion new garments per year (Muthu, 2015). Fashion retailers attract consumers by offering and selling a wide variety of styles, colors, and materials at very affordable prices. For instance, Americans consume nearly 20 billion garments a year (Cline, 2013). According to American Apparel and Footwear Association (2017), an average American bought around 68 garments and 8 pairs of shoes in 2016. Moreover, US consumers spent more than $€ 300$ billion ( $\$ 348$ billion) in clothing in 2011 whereas in Europe consumers spent more than $€ 400$ billion (\$476 billion) (Caro and Martínez-de-Albéniz, 2014). 


\section{Chapter 1}

\subsection{Operational Definitions}

This section introduces the main terms and their definitions adopted in this study. The textile and clothing waste is mentioned frequently throughout the manuscript, referring to the post-consumer textile, (used clothing that householders bought and no longer need), including linen and footwear. Textile collection refers to the amount of the textile waste that has been collected separately not being disposed at the refuse bin. The annual textile and clothing introduced in a local market is represented by $100 \%$, so the textile collection rate refers to the proportion of the used clothing collected out of that market. Similarly, textile collection is represented by $100 \%$, so the textile recovery rate refers to the proportion of the material recovered after sorting and recycling out of $100 \%$. Normally, textile recyclers can reach more than $90 \%$ textile recovery rate, which means $90 \%$ of the materials are re-used and recycled. After collection is taking place, more than $50 \%$ of the textile gets sorted into "re-use" as secondhand products and around $40 \%$ is sorted as "recycle" for producing other products. "Re-use" refers to the channel at which products are used again for the same purpose. Textile recycling refers to the processes required for producing other products such as new yarn, rags and thermal insulation.

\subsection{Research Purpose}

The problem to be resolved in this study is twofold. One part of the thesis investigates to which extent does the extended producer responsibility policy 


\section{Introduction}

provide social, economic and environmental benefits. The other part aims to determine whether the current practices of post-consumer textile collection and recycling are sustainable in France and Germany.

The purpose of this research is to aid policy makers and practitioners with better policies and reverse logistics network design for managing and recovering end-of-use resources in general and post-consumer textile in particular. The study identifies and highlights major areas with potential improvement, to ensure maximum economic, social and environmental benefits. It contributes theoretically to the existing knowledge of the textile recovery and reverse logistics models. The research exposes interesting insights and provides a roadmap that helps us to define the circular economy and characterize efficient material recovery programs.

\subsection{Research Scope}

The dissertation has been designed to have a clear focus and scope. The study examines the major operational aspects affecting the sustainability of the current collection and recovery of post-consumer textile. Drivers for textile recovery have been investigated in France and Germany. Post-consumer textile recovery involves different channels of collection, sorting, recycling, and re-distribution, so each of these activities have been described. Since France is the only country in the world adopting extended producer responsibility for textile producers, the study provides a great insight of how it is being implemented, what the benefits 


\section{Chapter 1}

are, and the challenges that the textile sector needs to overcome. The French and German practices of textile recovery give us a holistic view that increases our knowledge and awareness and emphasizes the benefits of developing a national recovery system for textile and clothing. They also show hidden limitations that we need to consider in the future to be able to promote sustainable improvement towards a circular economy transition. The dissertation is designed to describe the textile recycling practices in sufficient detail to allow other researchers to understand and gain valuable insights on such practices.

Some limitations exist as several areas have been excluded from the study. The focus of this research has been devoted to the managerial side of the textile recovery that aims to promote efficient material recovery programs by increasing collection productivity and reducing carbon emission footprint through a resource allocation approach. According to previous studies on textile recovery and recycling, we assume that the textile recovery provides greater ecological benefits to the society than landfilling and incineration; thus, textile recovery needs to be maximized. The study doesn't assess, in detail, the ecological, technological, and economic aspects of textile recycling. In addition, consumers' behaviors and awareness about the textile recovery are beyond the scope of this dissertation but interested readers can find such studies in consumer research articles. 


\section{Introduction}

\subsection{Research Process}

A mixed-methods evaluation has been conducted to systematically collect, observe and analyze information about the underlying policies and reverse logistics activities. Since qualitative research requires a recurring collection and analysis of data (Connaway and Powell, 2010), literature review and data collection have been realized in a cyclical process sequence as shown in Figure 1-1. The first literature review has been done to identify previous research gaps in textile recovery and then to make sure that the topics I select have not been assessed in previous literature. Then, another literature review has been conducted to justify the importance and researchers' interest in the topic. Later, I have conducted a qualitative research to understand the current trends of collecting and recovering post-consumer textile and clothing. Reviewing the previous literature on waste management and product recovery management gave me further exposure to other theories such as circular economy, sustainable development, and polluter pays principle. This exposure of the field and its relative concepts has led me to conduct additional literature review in "extended producer responsibility", "circular economy", and "sustainable development". In fact, literature review is a never-ending activity that we need to conduct until we contribute to the field and attain our findings. After having a solid theoretical framework, I conducted a pilot case study to characterize the post-consumer textile recovery in Germany. The German case has been selected as an extreme 


\section{Chapter 1}

case that could show strong textile recovery success. Germany, as a country, is a world leader in terms of the annual amount of overall waste and textile recovered. After characterizing the physical flow of the post-consumer textile and identifying the textile recovery activities, I have examined the French national textile recovery program using qualitative case research. The French case has been selected because it is the only case that can meet my criteria of having both a national program and extended producer responsibility policy. Currently, France is the only country in the world that implements such policy in the textile industry. Then, based on the French case findings, I have conducted an evaluative research using a linear programming method, one of the methods used in operations research to calculate the optimal solution, to assess the economic and environmental impacts of the current collection of textile and to determine the optimal scenario for such practices. These studies help us to give valuable insights not only in the textile recovery domain, but also in defining the circular economy and identifying important measures. 


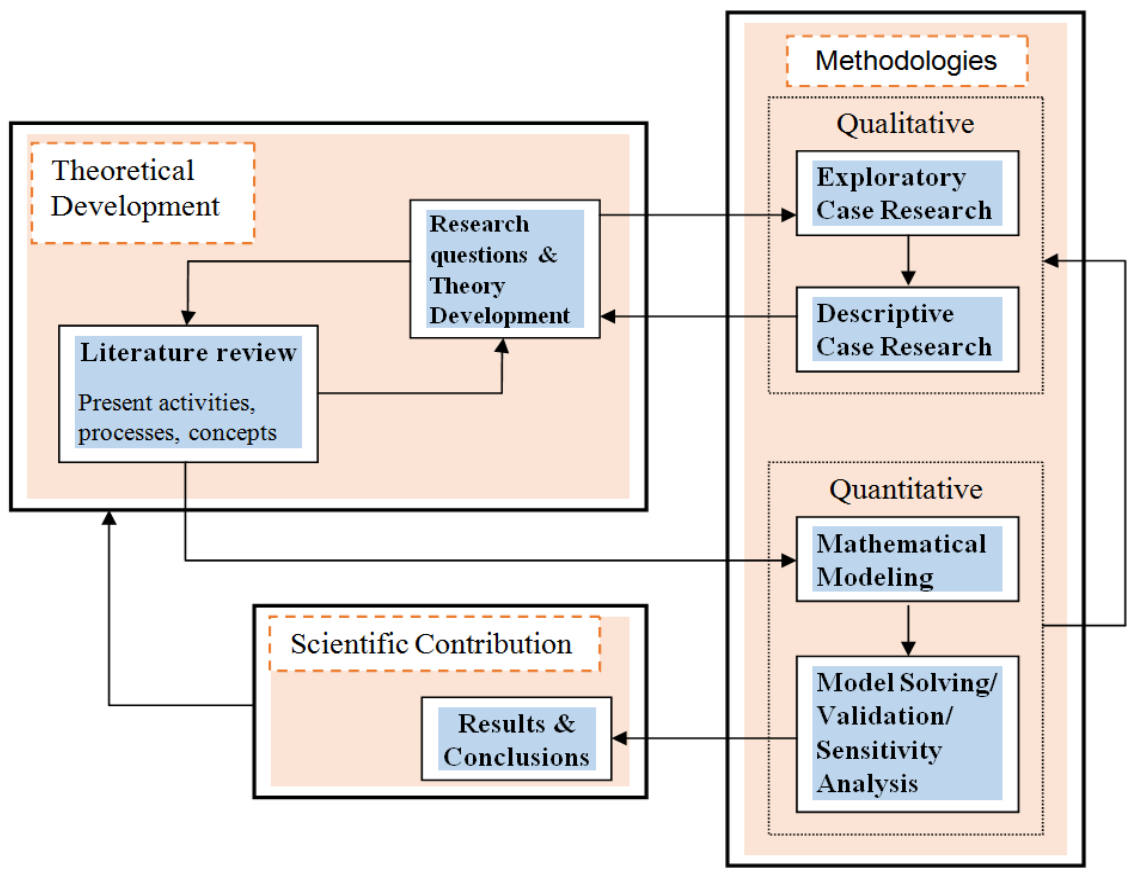

Figure 1-1 Research process and activities

\subsection{Research Outline}

This dissertation is composed of seven chapters. This first chapter provides an introduction regarding the research problem, scope, limitation, motivation, and purpose. The next chapter delivers a theoretical foundation for the research given as a literature review for the main topics studied during the investigation. Chapter three discusses some of the research methodologies used in the operations management research and justifies the methods used in this investigation. The fourth chapter represents qualitative case studies for examining the post-consumer textile and clothing recovery in France and Germany. A quantitative research is then conducted in chapter 5. It is to formulate and solve a simple linear programming problem to assess the current textile collection practices in France. It is also to propose a mixed integer linear 
programming model that can be adopted by textile recyclers and national associations to help them to organize the collection in the most economic manner. In chapter six, the discussion of the results found in chapter four and five takes place, followed by the conclusion section in chapter seven. 


\section{Chapter 2}

\section{LITERATURE REVIEW}

A fundamental part of any academic research is to review up-to-date existing academic literature in the field of study. Literature review helps us not only to position our research but also to give us different views and dimensions of the study of specific field. For doctoral research, it must involve a wide-ranging exploration of relevant literature across a range of different areas and disciplines. According to Karlsson (2009), researchers should consider achieving four goals while conducting a literature review:

1- To get informed with the existing state of knowledge relating to the field of study.

2- To be able to develop constructs, hypotheses and questions employed in the study.

3- To be able to find the right research methodology based on the justification of previous studies.

4- To develop and refine important research skills such as critical thinking, handling large information and creative writing. 


\section{Chapter 2}

Aligning these goals with the overall research objectives helps researchers to acquire new skills and knowledge while conducting their studies. Research activities have been always important for solving complex problems and promoting sustainable improvement in businesses, academics, and policymaking. However, without sufficient understanding of the investigated issue, researchers can't reach their research goals. Thus, literature review is what provides us with the sufficient knowledge and concepts that help us to identify potential improvement in the post-consumer textile collection and reuse.

\subsection{Sustainable Development}

There have been different approaches to promote sustainable practices around the world since the 1970's. The United Nations Environment Program (UNEP), founded in 1972, is the leading global environmental authority that sets global social and environmental goals and agenda to promote sustainable development. In 1987, the United Nations (UN) decided to establish the Brundtland Commission to unite countries to mutually work and pursue sustainable development. In its report "Our common future, the Brundtland Commission has defined sustainable development as "the development that meets the needs of the present without compromising the ability of future generations to meet their own needs". In 2015, 193 countries met at the UN to adopt 17 sustainable development goals (SDGs) need to be achieved by 2030 (United Nations, 2017). These goals primarily aim to improve the human health, education, nutrition and 


\section{Líterature Review}

living, protect natural resources from deterioration, protect the environment from air, water, and soil pollution, protect all organisms' diversity and evolution. From first of January 2016, the world has officially begun to implement the 2030 agenda to urgent global challenges.

Eco-efficiency is one of the sustainable development goals that proposed by the United Nations. Eco-efficiency is based on the withstanding concepts of reaching higher production efficiency to generate more output with less input and effort. The aim is to minimize the energy and resources used for the same amount of products produced previously and thus leading to fewer resource consumption, waste generation and pollution. Promoting eco-efficiency implies fostering natural resource preservation, industrial efficiency, and economic development. Eco-efficiency approach is not only valid for producing "new product", but rather, could be used for "end-of-use" products and materials waste that need to be processed in an integrative and pro-active production processes instead of being disposed and treated in a conventional manner.

The eco-efficiency has been expressed by the United Nations Economic and Social Commission for Asia and the Pacific (ESCAP) as a key element for promoting green economic growth by adopting sustainable production and consumption practices (UN, 2009). It is a general expression for the concepts of resource efficiency and productivity. Resource efficiency implies the use of less resources used when producing a unit of output, while resource productivity 


\section{Chapter 2}

implies the use of less resources to generate higher economic value (UN, 2009). The adoption of eco-efficiency principles can be mandated by government policies, technological improvements and/or market-based instruments (UN, 2009). The European Commission has adopted a broad definition of resource efficiency analogous to the United Nation's eco-efficiency concept. Hence, it has been defined as the sustainable consumption of the Earth's limited resources to create more products having greater value with the use of less resource input (EC, 2017).

Meeting these goals requires efficient governance and system behavior change. We need cleaner production technologies, renewal ecological substitutes for our resources, ethical practices and social responsibility when we do businesses, and investment to improve people life and to protect the environment. However, these practices cannot be reached unless efficient methods have been adopted to manage and assess the economic, social, and environmental impacts of the fragmented supply chain processes.

\subsection{Circular Economy}

Over the last decade, we have witnessed an increasing political interest in promoting circular economy, especially in the industrialized economies. The circular economy aims to change the paradigm of the so-called linear economy through increasing resource efficiency and turning waste into a valuable resource. It also aims to achieve the sustainable consumption and production 


\section{Líterature Review}

goal that has been introduced in United Nations' agenda for achieving sustainable development (European Parliament, 2016). The European Commission has adopted a Circular Economy Package to stimulate Europe's transition towards a circular economy and to foster sustainable economic growth and employment opportunities. Circular economy is sometimes seen as a model that has a wide focus on environmental and social sustainability issues, so we intend to set the boundary of the circular economy and to highlight its scope and limitations in the context of the textile sector.

Despite its modern appealing, circular economy (CE) is not a new theory and it has been developed many decades ago. The $\mathrm{CE}$ is an extension for the sustainable development movement laid in the 1960s aiming to decouple the economic growth from resource utilization and environmental degradation (EC, 2016). The circular economy has been described in the EU circular economy action plan as the economy that generates minimum amount of wastes and maintains highest value of products, materials and resources for a long period (European Parliament, 2016). In 2016, the EC proposed new targets substituting the previous Waste Framework Directive by a Circular Economy Package, setting the recovery target for municipal waste to $70 \%$ and limiting the share of municipal waste to be landfilled to $10 \%$ by 2030 (European Parliament, 2017). In this dissertation, the circular economy has been examined to identify its limitations on addressing sustainable practices in textile recovery. Some 


\section{Chapter 2}

researchers (ex. Andersen, 2007) argue that the circular economy is not achievable since it cannot ensure 100 percent recycling, but that doesn't restraint its valuable implication. The implementation of circular economy is not mature yet and it is still having some limitations in the practice. Velis and Vrancken (2015) state that developed countries under circular economy transition ship major amount of end-of-use materials abroad for processing and recycling, which raise major concerns regarding the environmental performance of such transition.

Recycling programs have been broadly adopted globally for improving material efficiency and avoiding potential negative ecological consequences of waste disposal. Improper waste disposal and treatment result in a loss of valuable resources and environmental damage. End-of-use products such as packaging, electronics, and textile are piling up faster than ever before especially in industrialized economies such as America, China, and several countries in Europe. Thus, the development of waste management and recycling programs has been paid considerable attention from our governments to ensure that these products are treated in cost-effective and environmentally sound manner. Recycling programs may have several advantages in terms of energy and material recovery. Producing new products made of recycled materials such as for the case of aluminum, plastic, newspaper and glass, require less energy and material extraction than producing products from new raw materials. Recycling 


\section{Líterature Review}

programs should encourage both consumers and businesses for recycling and should develop efficient systems for collection, transportation, sorting, recycling and reuse. Logistics systems should provide consumers with the ease and convenience to recycle and reduce economic and environmental burdens from transporting, sorting and recycling the materials. Thus, promoting structural transformation, effective governance, and effective logistics system could guide industries to recover the waste in a cost-effective, innovative, and ecological manners. An important, but often overlooked, consideration in understanding the circular economy is understanding the flow of recyclable materials. Much focus has been put on recycling and material recovery without bearing the limitations of these practices and their impacts on other societies. This dissertation addresses these issues for the textile and clothing industry from the operational and logistics perspective to fill the gap of the current literature.

The Circular Economy Package entails four legislative proposals on waste: 1) amending Directive 2008/98/EC on waste, 2) amending Directive 1999/31/EC on the landfill of waste, 3) amending Directive 94/62/EC on packaging and packaging waste, and 4) amending Directives 2000/53/EC on end-of-life vehicles, 2006/66/EC on batteries and accumulators and waste batteries and accumulators, and 2012/19/EU on waste electrical and electronic equipment. However, amending of aforementioned directives implies that all waste and 
landfilling targets will be reported in the Circular Economy Package (European Parliament, 2016).

Even though previous definitions of CE are not precise and don't have criteria for assessment measures (Haas et al., 2015) many researchers perceive it differently. Charonis (2012) and Schneider et al. (2010) perceive it as another term for "de-growth" for social equity, ecological sustainability and "steady state" economics. Kallis (2011) also defines it as "a socially sustainable and equitable reduction (and stabilization) in a society's throughput where throughput denotes the materials and energy a society extracts, processes, transports and distributes, to consume and return back to the environment as waste". The circular economy is still theoretically promising, without a clear vision, policies, and indicators. Thus, it should be embedded in the national economy framework with a clear vision. Ghisellini et al. (2016) argue that the CE could provide a reliable framework, if preliminary actions and strong commitment have taken extensively worldwide towards improving business model and promoting preventive and regenerative eco-industrial development. We discover in this study the EU circular economy package and what actions are required to promote a sound circular economy framework in Europe.

\subsection{Overview on Textile and Clothing Production}

Cotton and polyester are two fibers that have different physical characteristics and are the most used fibers in our clothes. Cotton is natural fiber and is 


\section{Líterature Review}

breathable, comfortable and good for sensible skin while polyester is synthetic that is stronger and durable than cotton. Cotton can change its shape and is naturally shrinkable while polyester does not shrink easily because of its chemical composition and it holds its shape better than cotton. When these fibers are mixed the result is strong, durable and breathable clothes that can hold its shape and color compared with cotton only. These fibers endure many production processes that use large amounts of water and energy and have a great impact on human health and environment.

The demand for cotton and polyester fibers are increasing. The global clothing market is continuously growing and it is of utmost importance to the economy in terms of trade, employment, investment and revenue all over the world (Business Wire, 2016). Cotton is the world's most widely traded agricultural commodity and the demand for polyester fiber is growing rapidly. Approximately each year, 20 million tons of cotton are produced in about 90 countries (WWF, nd). China, United States, India, Pakistan, Uzbekistan and West Africa account for over $75 \%$ of global production. Cotton represents nearly half the fiber used to make our clothes and other textiles worldwide, with much of the rest coming from synthetic products (as highlighted in the 2003 WWF report Thirsty Crops http://assets.wwf.org.uk/downloads/thirstycrops.pdf).

Cotton is a slow-growing plant that requires at least 160 frost-free days to grow and it is subject to infestation. Therefore, many farmers heavily douse the plant 


\section{Chapter 2}

in pesticides that are harmful to human and animal health. Pesticides compromise as much as $50 \%$ of the cultivation costs for many farmers this has led to debt and bankruptcy among poor farmers. About two-thirds of an acre's harvest volume is discarded, leaving one-third of the harvest volume available for textile production. Only one-third of the harvest volume is available for textile production while remaining is discarded. With the trend getting better for polyester fiber there has been fluctuating demand for cotton and this has severely affected the farmers and their income.

In Gujarat, the largest Indian state for cotton production in India, half of the ginning plants were shut down due to economic crisis in 2015. Dhiren Sheth, the president of Cotton Association of India stated that the cotton price in India has been affected due to decreased Chinese demand for cotton (YarnsandFibers, 2015).

With half of total fiber (manmade and natural) market coverage, polyester fiber is the most used and preferred in textile industry. The production of apparel was around 50 per cent of the total polyester fiber end-uses in 2016 followed by home furnishing for 25 percent of polyester volumes produced. Polyester yarn dominated the global demand for polyester fiber accounting for 68 percent of total use. Asia is the largest consuming region globally where the fast-growing textile industries consume the increasing amount of polyester fibers. 


\section{Líterature Review}

Fiber production has a great impact on our society. Despite the global trade of its agricultural commodity, cotton is one of those most toxic to grow. Synthetic fertilizer and pesticides are used heavily by farmers to fight against bollworm infestation. The use of genetically modified (GM) seeds have reduced the use of pesticides, but still require special fertilizers and irrigation system that may pollute water resources, air and surfaces that can endanger human and animals' health. Mono-crop cultivation reduces the future soil enrichment. Cotton does not return nutrients to the soil as other fiber crops do naturally. Cotton is thirsty crop so large quantities of water consumption are required. It is estimated that 1,400 to 3,400 gallons of water are used for each pound of fiber (half pound fiber is required to make one t-shirt). The impact of producing polyester fiber may vary on the method used to produce it. These methods depend on the form the finished polyester will take. The four basic forms are filament, staple, tow, and fiberfill. Smooth surfaced fiber is produced in filament form while in staple form, filaments are cut to short predetermined lengths. In tow form the continuous filaments are drawn closely together and fiberfill is voluminous form used to produce quilts, pillows, and outerwear. Filament and staple are the most frequently used forms. Polymerization, dying, melt spinning, drawing the fiber, and winding are five stages of filament yam production. Polymerization, drying and melt spinning and drawing tow, crimping and cutting are the stages used for staple fiber production. Lots of hazardous emissions are released to the 
environment during the production of polyester fiber. The dyes not remaining on fiber are released into water that can harm the environment. In populous countries like China and India, the social impact of the industry is mainly due to the lack of laws regarding wages and environmental standards.

Understanding the impact of the fashion industry on the society and environment encourages us to minimize such damages resulting from the textile life cycle. Life cycle of textile includes production, preparation (processing, dyeing, manufacturing, transportation, product use (wear, use, ironing, washing and drying) and disposal (recycling, repair and landfill). In each phase there could be a potential threat to public health as well as to the environment.

\subsection{Sustainability in the Fashion Industry}

The fashion industry requires more attention to promote sustainable practices along the supply chains. Various authors have addressed environmental and social issues within the fashion industry. De Brito et al. (2008) claim that the fashion retail faces very severe challenges to overcome the need for economic, social, and environmental sustainability. They also declared that the compatibility between sustainability and economic growth is still one of the major concerns in the literature. Many textile producers and fashion retailers, such as Nike, Levi Strauss and H\&M, have been blamed lately because of inhuman working conditions and environmental contaminations (Seuring \& Müller, 2008). For instance, the Rana Plaza building, a house for number of well- 


\section{Líterature Review}

known fashion retailers in Bangladesh, has collapsed in 2013 and led to more than one thousand workers to die. Siegle and Cline (cited in Caro \& Martínez-deAlbéniz, 2014) believe that fast fashion business model is unsustainable by nature as it encourages producing low durable, low quality and short life garments in unhealthy environment.

The textile and fashion industry is one of the most polluting and socially challenged industries in the world (Strähle and Müller, 2017). Fashion industries have produced clothes in global scale with short life cycle, low predictability with high impulse buying (Fernie et. al, 2010). The return rate of the apparel industry is about $19.4 \%$ and it is almost three times more than return rates of other industries (Norek, 2002) .If it is ignored, based on the above statement, the main companies' loss can be lost profits due to recovery, recycling and selling components, products material or return the product and damaged customer relationships and external liabilities that could have an enormous impact on their business. However, reverse logistics can enable organizations to improve profits and customer satisfaction and minimize cost (Venkatesh, 2010).

Fashion industry is a significant business as it is vastly and influencing our economy, society and the environment. Therefore, it requires more attention and transformation to stimulate circular economy and sustainability-oriented business models. The industry is the largest in terms of investment, revenue, 


\section{Chapter 2}

trades and employment generation. It is also considered one of the economy pillars in some countries like China, Bangladesh, Vietnam, India and Sri Lanka.

Nowadays, the raising interest, from consumers and researchers, in sustainable practices within the textile industry, may stimulate new social and environmental regulations. Particularly, the last 5 years have witnessed a rapid increase of research in the sustainable supply chains practices within the fashion industry (Figure 2-1). Searching for combined keywords such as ["sustainable" + "sustainability" + "textile" + "fashion"] in Scopus database has led to identify 296 potential papers in the field. These papers were published between 1994 and 2017. Half of the papers were published in the last 5 years. Since 2010, the field has been of increasing interest from researchers. The main journals that published more than 15 papers are Journal of Cleaner Production, Sustainability (Switzerland), Journal of Fashion Marketing and Management, and International Journal of Consumer Studies as shown in Figure 2-2. The papers have then been filtered, sorted and classified according to their relevance to the value chain activities as shown in Figure 2-3. These studies are listed in appendix A. 
Literature Review

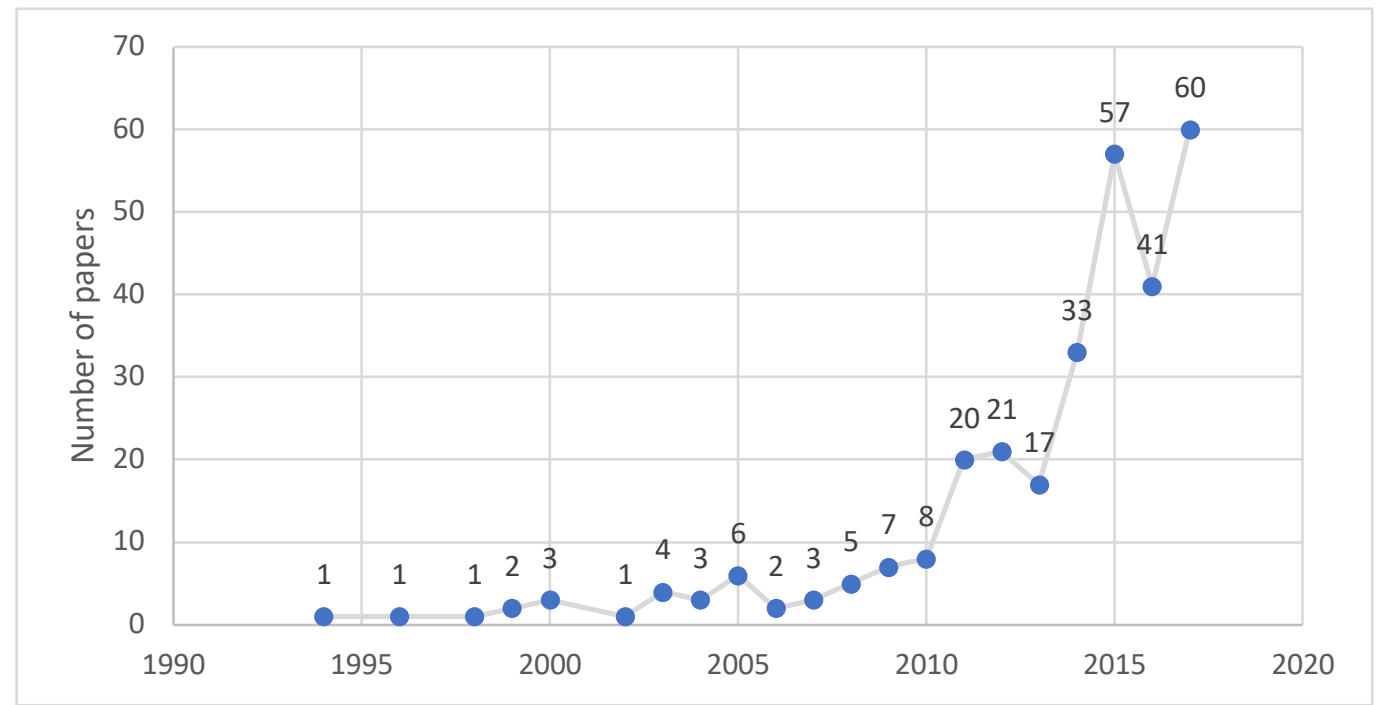

Figure 2-1 Distribution of publications per year

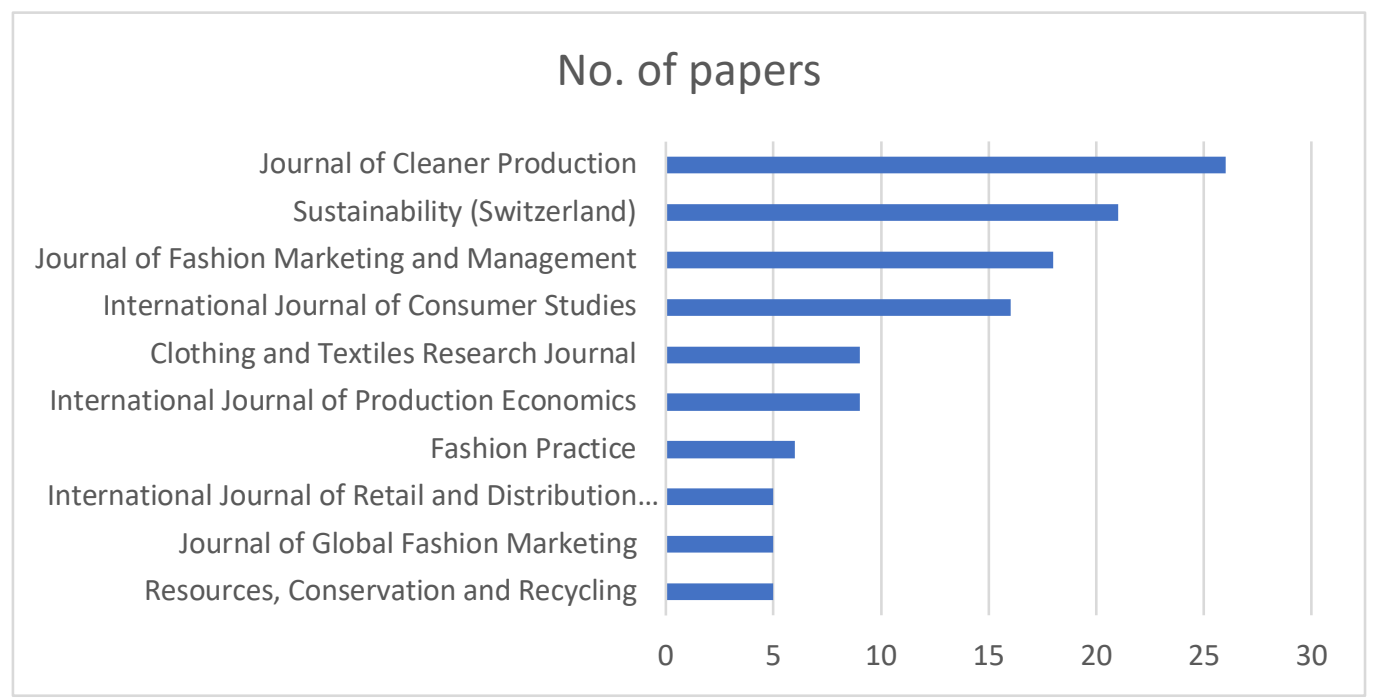

Figure 2-2 Journals having 5 publications or more 


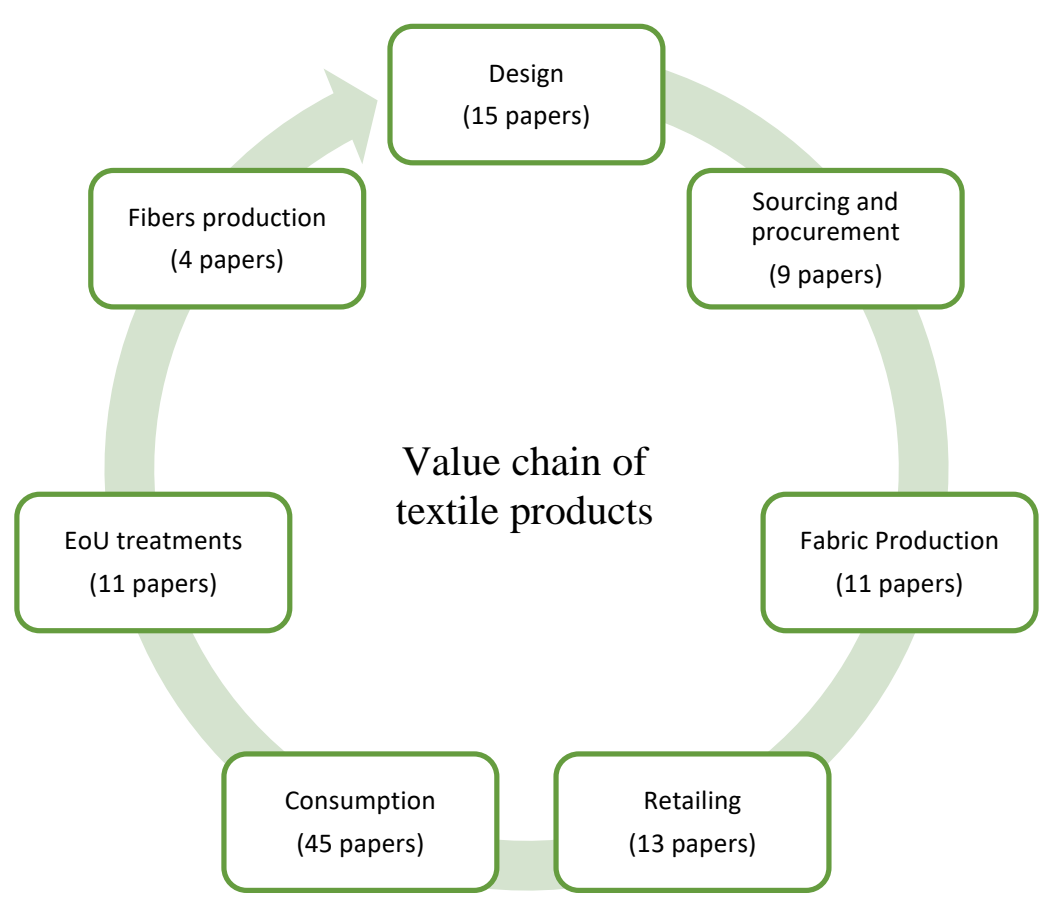

Figure 2-3 Number of published papers different areas in the value chain

It is observed that the share of papers that address consumer behavior for purchasing and disposal is dominant followed by the end-of-use treatments. However, all value chain activities need to be considered when dealing with the sustainability in textile industry. Improving all value chain activities implies overall improvement in the sector, while improving some activities implies partial improvement in the sector.

Textile waste is relatively small in terms of weight as compared to other waste streams, but it has a large impact on human health and environment, and its rate is increasing due to the "fast fashion" model. From 2005 to 2014, the US generation of textile and clothing waste increased $40 \%$ (see Figure 2-4). The graph also shows the rapid increase of the amount of textile waste generated between 


\section{Líterature Review}

2010 and 2014. Moreover, the total cost of managing the textile waste rose from \$2.4 in 2003 to \$3.5 billion in 2013 and might reach $\$ 4.5$ billion in 2020 (Johnson \& Adler, 2017). The cost of the textile waste sent to landfill is about $\$ 45$ per ton in the US (Wicker, 2016) and $€ 60$ per tonne in some countries in Europe, including France (EC, 2002). Apparel consumption has increased dramatically during the last few decades. The current business model, the fast fashion, characterized by mass production, variety, agility and affordability, has been adopted by large international fashion retailers. According to Pedersen and Andersen (2013), fast fashion creates a demand for 80 billion new garments each year (Cline, 2013). Fashion retailers attract consumers by offering and selling a wide variety of styles, colors, and materials at very affordable prices.

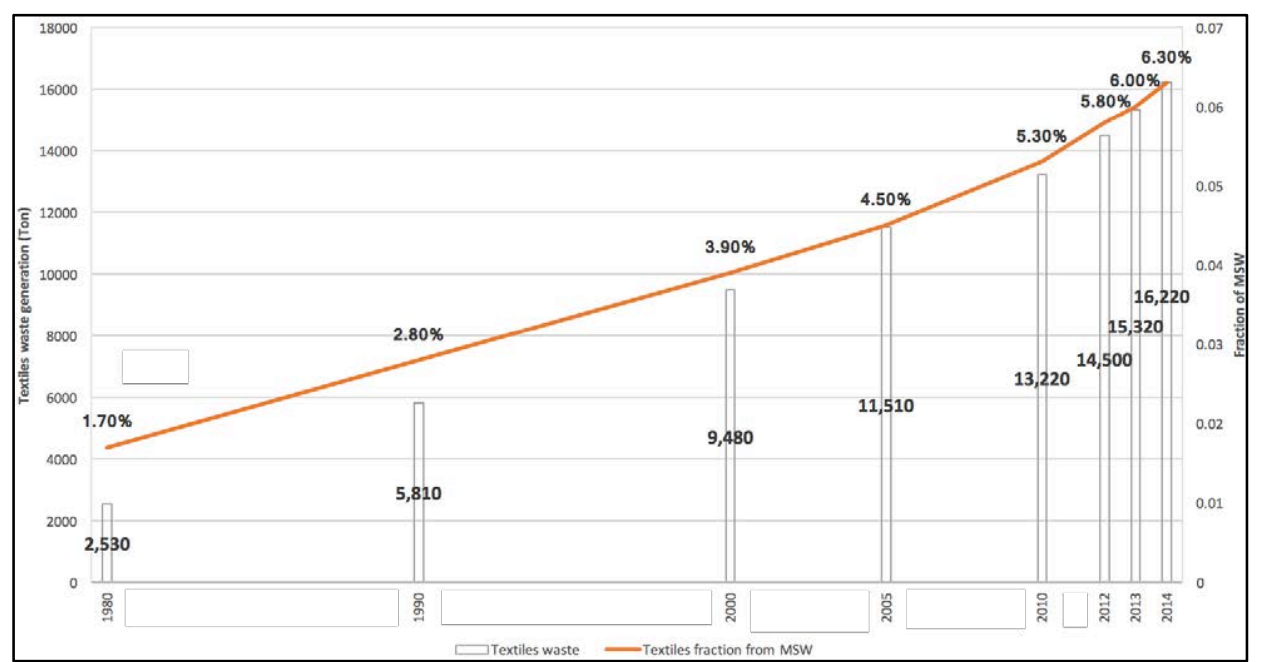

Figure 2-4 Textile waste generation in the US

Own development based on (EPA, 2014)

Textile recycling is becoming critical, as approximately two-thirds of clothing materials are nowadays sent to landfills, making it the fastest growing 
component of waste in the household waste stream. Within the last five years, textile disposed of in landfill sites have risen from $7 \%$ to $30 \%$ of the total waste in it (Lee, 2009). Moreover, in the European Union throws away around half a ton of household rubbish every year and around 8,7 percentage of the total is from the textile industry. According to the European Commission, European consumers discard around 5.8 million tonnes of textile every year and only $26 \%$ is being recycled (Beasley \& Georgeson, 2014). The amounts of annual textile waste that goes to a landfill in the UK and the US are estimated to be 350,000 tonnes and 9.5 million tonnes, respectively (WRAP 2012; Council for Textile Recycling). Similarly, about 100 thousand tonnes in Hong Kong and 20 million tonnes in China are being landfilled annually (Kao 2015; China National Textile \& Apparel Council, 2013). Thus, China and USA landfill larger amounts of textile per capita compared to Europe and the U.K. as shown in Figure 2-5.

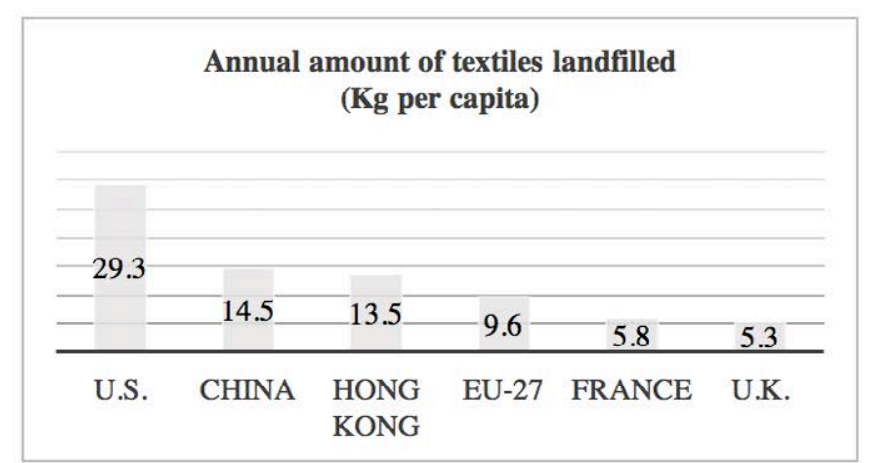

\begin{tabular}{|c|c|}
\hline Country & $\begin{array}{c}\text { Population } \\
\text { (in million) }\end{array}$ \\
\hline U.S. & 323.9 \\
\hline China & $1,378.0$ \\
\hline Hong Kong & 7.4 \\
\hline EU-27 & 446.0 \\
\hline France & 67.0 \\
\hline U.K. & 65.8 \\
\hline
\end{tabular}

Figure 2-5 Estimation for the annual amounts of landfilled textile in different countries in 2016

It takes more than 20,000 liters of water to produce a $\mathrm{kg}$ of cotton, equivalent to a single cotton T-shirt or a pair of jeans (WWF, 2018). The fiber production 


\section{Líterature Review}

reached 82 million tonnes in 2012 (The Textile Magazine, 2013), which requires 131 million tonnes of coal and around 1.2 trillion UK gallons of water to produce (Cline, 2013). Samples of different brands have been tested by Greenpeace to find out that most of the clothes we wear contains toxic chemicals and two-thirds of the samples contains nonylphenol ethoxylate (NPE) which degrades to nonylphenol (NP) when released into the environment. NP is named a "priority hazardous substance" under the EU Water Framework Directive. In addition, two items produced by Zara have been found to contain cancer-causing amines from the use of AZO dyes (GreenPeace, 2012).

Member States are required to reduce the amount of wastes sent to landfill. The EC Landfill Directive 1999/31/EC enforced Member States to reduce the disposal of biodegradable municipal waste to landfill to $75 \%$ by 2006 , to $50 \%$ by 2009 and to 35\% by 2016 (EC, 2016a). The objective of the directive is to protect human health and to reduce the environmental impact on surface water, groundwater, soil, air, and on human health from the landfilling of waste. The directive also requires Member States to introduce stringent technical requirements for waste sent to landfills. The European Commission has proposed to reduce landfill to a maximum of $10 \%$ of municipal waste by 2030 (EC, 2016b). Thus, finding alternatives for diverting textile from landfill is not only necessary to achieve that target, but also to increase the materials efficiency, which is a vital element for promoting circular economy. 


\section{Chapter 2}

Caro and Martínez-de-Albéniz (2014) have defined it explicitly as a business model that responds quickly to the demand and delivers affordable fashionable clothes with frequent assortment changes, mostly for young consumers under 40. They list fast fashion retailers according to the number of appearance in both Factiva database and PDF online search as shown in Table 2.1. Unquestionably, H\&M and Zara are considered the focal retailers in this business model.

Table 2.1 Number of times specialty apparel retailers has been mentioned as a fast fashion in media publications

Source: (Caro and Martinez-de-Albeniz, 2014)

\begin{tabular}{lccccc} 
& $\begin{array}{c}\text { number of appearances } \\
\text { in Factiva search }\end{array}$ & & \multicolumn{2}{c}{$\begin{array}{c}\text { number of appearances } \\
\text { in PDF online search }\end{array}$} \\
\cline { 2 - 3 } \cline { 5 - 6 } Specialty apparel retailer & rank & \% appearances & & \% appearances & rank \\
H\&M & 1 & $31.7 \%$ & & $41.0 \%$ & 2 \\
Zara/Inditex & 2 & $29.2 \%$ & & $45.9 \%$ & 1 \\
Gap & 3 & $11.9 \%$ & & $18.2 \%$ & 3 \\
Uniqlo/Fast Retailing & 4 & $9.9 \%$ & & $9.4 \%$ & 8 \\
Topshop & 5 & $9.3 \%$ & & $13.7 \%$ & 4 \\
Forever 21 & 6 & $7.5 \%$ & & $11.2 \%$ & 6 \\
Mango & 7 & $4.3 \%$ & & $12.4 \%$ & 5 \\
Wet Seal & 8 & $3.2 \%$ & & $0.6 \%$ & 16 \\
Benetton & 9 & $3.1 \%$ & & $10.1 \%$ & 7 \\
New Look & 10 & $2.8 \%$ & & $6.2 \%$ & 9 \\
Esprit & 11 & $2.8 \%$ & & $4.7 \%$ & 10 \\
C\&A & 12 & $1.9 \%$ & & $4.7 \%$ & 11 \\
American Apparel & 13 & $1.2 \%$ & & $2.6 \%$ & 13 \\
Urban Outfitters & 14 & $0.9 \%$ & & $2.8 \%$ & 12 \\
Peacocks & 15 & $0.5 \%$ & & $1.1 \%$ & 15 \\
Charlotte Russe & 16 & $0.5 \%$ & & $0.2 \%$ & 17 \\
Armani Exchange & 17 & $0.3 \%$ & & $1.5 \%$ & 14
\end{tabular}

Low quality fashion has a shorter life cycle leading to a great textile waste and disposal. Unfortunately, textile waste can cause unexpected environmental and health problems if they have not been managed appropriately. Therefore, the need to improve our waste management system has led the federal governments and policy makers to issue new legislations and waste prevention plan to reduce waste and recover used materials. 


\section{Literature Review}

\subsection{Waste Management Policies in Europe}

As we examine textile recovery and recycling in this dissertation, it is worth mentioning important aspects of waste management that are relative to the study. Recycling is not only a reverse logistics activity, but also one of the treatment processes for managing the waste. Waste management refers to the supervision of waste material handling from waste generation at source to disposal destination, passing through material recovery processes including recycling (OECD, 2001). Managing the waste aims to offer solutions for collection, transportation, and disposal of garbage, sewage, plastics, glass, paper and other waste products. Waste management differs from country to country, even within the EU. Some countries, like Germany, Belgium, and Netherlands encourage sorting the material into different elements at source, while other countries like the United states and Saudi Arabia, may sort some of the wastes at a sorting facility after collecting mix material garbage. In addition, some countries rely on landfill as a major channel for waste disposal while others may rely on incineration, energy recovery, or recycling.

Managing the material waste efficiently and cost-effectively is an every-day challenge that societies face all times. The amount of waste is increasing at a faster pace and its nature is dynamically changing due to the complexity of recycling and treating products composed of different materials mix and due to the rise in hi-tech products that contain precious metals and hazardous materials. (EC, 


\section{Chapter 2}

2010). Thus, waste management policies in Europe have been increasingly introduced to protect societies from the potential risk of waste in health and environment and to improve the resource efficiency in Europe (EC, 2010). Through appropriate practice of waste management, Europe needs to promote resource efficiency and sustainable economic growth.

The cornerstone for the European waste policy is the EU Waste Framework Directive. The European Waste Framework Directive (2008/98/EC) sets the basic concept of waste management by introducing the five-step waste hierarchy (see Figure 2-6) in the following priority order: waste prevention, preparing for reuse, recycling and ultimately disposal (EC, 2008). It also sets the material conservation target to be achieved by 2020; that is, diverting over $50 \%$ of municipal waste from landfills by preparing for reuse and recycling. The EC Landfill Directive 1999/31/EC enforces Member States to reduce the disposal of biodegradable municipal waste to landfill (EC Environment, 2016a). It requires Member States to introduce stringent technical requirements for waste sent to landfills. The European Commission has proposed to reduce landfill to a maximum of $10 \%$ of municipal waste by 2030 (EC Environment, 2016b). Thus, finding alternatives for diverting textile from landfill is not only necessary to achieve that target, but also to increase the materials efficiency, which is a vital element for promoting circular economy. 


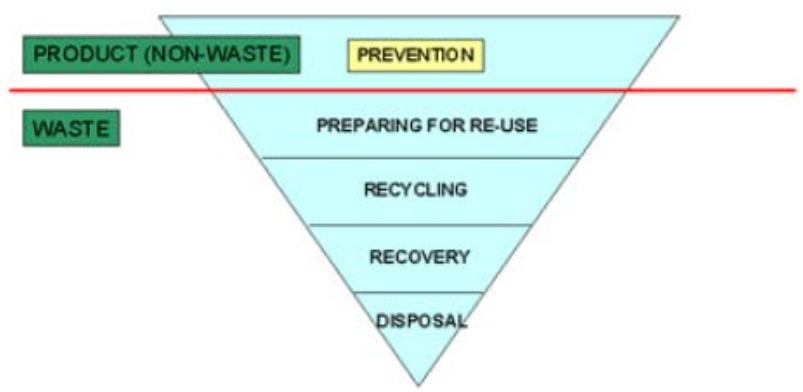

Figure 2-6 European Commission waste hierarchy

Source: (EC, 2016)

Textile waste management has not been governed by strict regulations to avoid improper disposal and encourage material recovery like other material waste streams such as batteries, electronics and electrical equipment, end of life vehicles and packaging materials. Each of these waste streams have been governed by an extended producer responsibility policy attached to a specific directive to maintain specific targets and regulations, for instance, Directive 2006/66/EC on batteries, Directive 2012/19/EU on waste electrical and electronic equipment (WEEE), Directive 2000/53/EC on end-of-life vehicles (ELV), and Directive 94/62/EC on packaging and packaging waste. Textile waste might account for very small proportion compared to these streams, but its potential reuse and recycling rates are very high comparing to other recyclables (Horrocks, 1996; Hawley, 2009). To overcome the challenges of achieving the overall EU landfilling and recycling targets, France has imposed an extended producer responsibility policy on textile and clothing to maximize its material recovery rate and efficiency towards circular economy transition. 


\section{Chapter 2}

\subsection{Extended Producer Responsibility}

Governments are facing increasing challenges to promote efficient recycling programs. A study by Waste Management of North America, Inc., found that the cost of collecting and sorting the material exceeds the value received for recyclables (Grove 1994). When the recycling costs outweigh the material value, governments need to subsidize these activities to maintain recycling. The material value is induced by the oversupply of recyclable materials, thus, as more recycling of materials occurs, the value of recyclables declines (Wright et al., 2011). The increasing supply of recycled materials governed with a price depression may require higher government subsidies to support recycling operations. Thus, governments are challenged to face the increasing trend of subsidizing recycling activities to reduce the economic and environmental burdens. Failing to support reverse logistics activities including collection and recycling would lead to material to flow to undesirable channel such as landfilling and incineration.

A potential shortage of landfill space and the increase of the waste generation have intensified the government interest in promoting recycling. For reducing the waste, a series of enacted legislation and polices issued by European Commission and national federal governments have governed some retailers to hold responsibility for their products until after consumption. This environmental instrument, Extended Producer Responsibility (EPR), has been 


\section{Literature Review}

introduced at an increasing rate in many developed countries around the world. It is considered one of the effective tools required for promoting waste recovery and remanufacturing especially for harmful or reusable materials that can be found mainly in the computer and electronics industry. Germany, France, and Netherlands are some of the countries that already implemented EPR policy for various products other than electronics such as papers, tires, cars, batteries, and chemicals. As of today, textile and clothing have never been legalized except in France where it has been declared in 2007. France is officially the only country enacts the EPR for fashion retailers and producers to hold responsibility for their products after EOL. Thus, fashion retailers and producers are reacting and proacting to these policies by prioritizing the sustainability in their agenda.

The EPR has been defined by the Organization for Economic Co-operation and Development (OECD) as an environmental policy approach in which producers are responsible (physically and/or economically) for the collection, treatment, and disposal of their products at the post-consumer stage of a product's life cycle (OECD, 2001). It aims to drive and incentivize producers to: develop a sustainable production system and product design to make them durable and easier to repair and recycle; develop innovative techniques for recycling processes; and create new markets for recycled products (EC, 2015). In the EPR setting, producers can either develop their own individual collection and recycling system, or can join a collective scheme, where different producers 
contribute to a producer responsibility organization (PRO) to leverage economies of scale. However, researchers argue that the collective scheme doesn't offer enough incentives for promoting waste prevention and green product design (Plambeck \& Wang, 2009; Atasu \& Subramanian, 2012; Esenduran \& Kemahlioglu-Ziya, 2015).

Different accreditation systems for collective producer responsibility exist. The EPR policy was initially established with a single PRO operating as a monopoly such as the previous German dual system for packaging. Evidence of inefficiency and cost increment has led to an increasing number of EPRs that involve multiple PROs. On the other hand, it has been argued that EPRs having monopoly PROs can benefit from exploiting economies of scale, addressing freeriders and reducing the costs of regulatory oversight (OECD, 2016). The conditions in which a monopoly PRO is more efficient than multiple PROs have not been determined. This study gives more insight on the EPR implementation of a single non-for-profit PRO, accredited as a producer responsibility organization for textile industry.

\subsection{The Role of Reverse Logistics}

Reverse Logistics (RL) has been expanded widely because of its multidisciplinary character and its ecological and economic importance. Current environmental issues like a scarcity of landfills, harmful emissions and depletion of non-renewable resources have increased both governments and consumers 


\section{Líterature Review}

concerns for having proper products treatment at end of life (Georgiadis and Vlachos, 2004). Reverse logistics has become more prominent in both the business community and academia in the last few years, covering by other areas like recycling, remanufacturing, warehousing, operations, and environmental sustainability (Lee et al., 2009; Hazen et al., 2011; Ponce-cueto and Carrascogallego, 2011; Dowlatshahi, 2012). Moreover, implementing RL programs are resource intensive and must be committed in time and resources significantly (Daugherty et al., 2001). Generally, managing the reverse flow of EoU materials is costly and complex (Guiltinan and Nwokoye, 1975; Singh et al., 2014). Due to relatively low volumes of recyclables are being collected and irregularity of reverse movements, the transportation problem to minimize the cost has proved economic significance since many decades ago (Guiltinan and Nwokoye, 1975).

Reverse logistics represents the backward flow from consumers and end-users to producers and retailers. It is the opposite process of the forward logistics. Since logistics is defined by The Council of Logistics Management as "the process of planning, implementing, and controlling the efficient, cost effective flow of raw materials, in-process inventory, finished goods and related information from the point of origin to the point of consumption for the purpose of conforming to customer requirements" (Rogers and Tibben-Lembke, 1998), hence, reverse logistics is "the process of planning, implementing, and controlling the efficient, cost effective flow of raw materials, in-process inventory, finished goods and related information from the point of 


\section{Chapter 2}

consumption to the point of origin for the purpose of recapturing value or proper disposal"(Rogers and Tibben-Lembke, 1998). The reverse logistics flow is different from the forward flow. The majority of reverse logistics flows are much more reactive and with much less visibility (Rogers et al., 2012). Fernie and Sparks (2004) have defined RL as a process that facilitates the reuse and recycling of unwanted materials to become alternative for new raw materials in the production stage. Companies and manufactures positioned under increasing pressure to collect and dispose properly from down-stream and to reduce emissions and recover the residual value of the waste (Huang and Yang, 2014). In addition, extended producer responsibility, warranties, and selling product with higher return rate are making other causes why companies have to consider reverse flows of products (Sas, 2013).

In the last two decades, many researchers contributed significantly in the SC management targeting the green/sustainable supply chain, forward/reverse supply chain and closed-Loop supply chain Management. Recently, the reverse logistics activities which are part of the closed-loop chain cycle have gained much interest from the OM researchers as a mean to close the loop of products life cycle. Closed Loop Supply Chain (CLSC) refers to the integration of forward and reverse flow when designing new products and planning for distributions and acquisitions. The modern definition of CLSC is "the design, control, and operation of a system to maximize value creation over the entire life cycle of a product with dynamic 


\section{Literature Review}

recovery of value from different types and volumes of returns over time" (Govindan et al., 2015). Guide and Van Wassenhove (2009) reported that CLSC "refers to all forward Logistics in the chain (like procurement of materials, production and distribution) as well as the Reverse Logistics to collect and process returned (used or unused) products and/or parts of products in order to ensure a socioeconomically and ecologically sustainable recovery". To simplify the concepts, we illustrate the concept of closed loop supply chain in Figure 2-7.

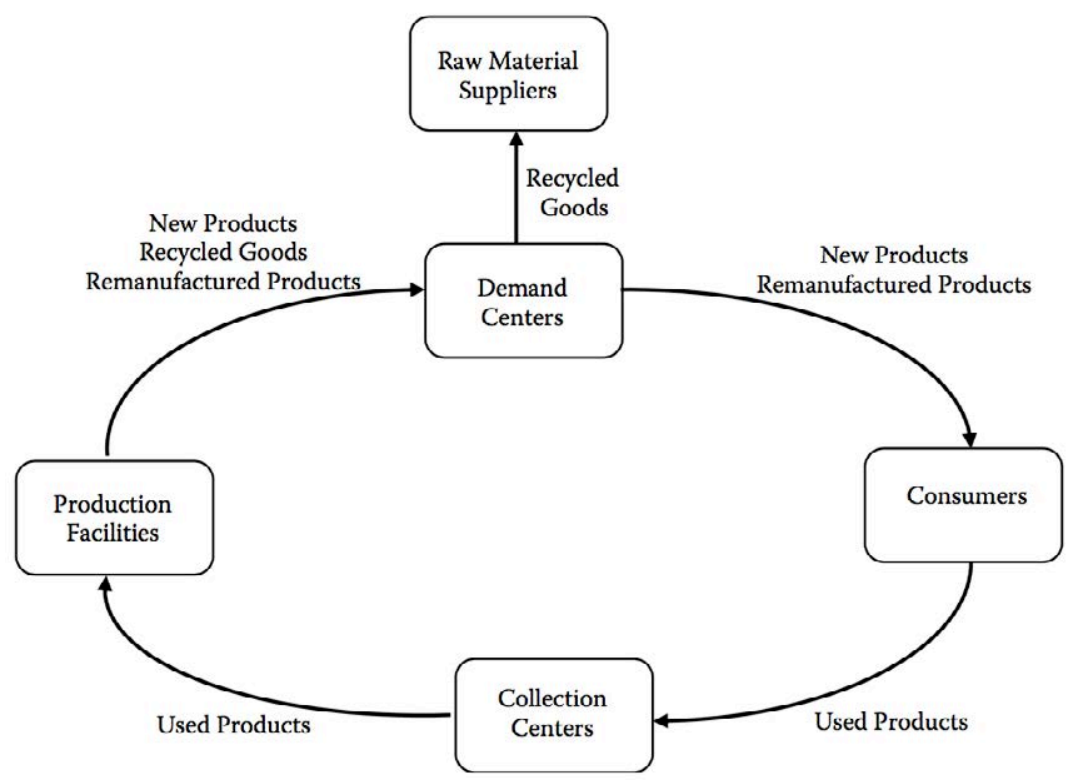

Figure 2-7 Generic form of Closed Loop Supply Chain

Source: (Pochampally et al., 2009)

There are different terms interchangeably used to refer to the concept of reverse logistics such as reverse distribution and reverse supply chain (RSC). However, Guide and Van Wassenhove (2009) have distinguished "reverse logistics" from "reverse supply chain" by limiting the RL scope to "moving used products to reprocessing facility" so that RL is considered one of the reverse 
supply chain activities which are used-product acquisition, inspection and disposition, remanufacturing, re-marketing and disposal. The term "reverse" is sometimes confusing because it doesn't always mean that the product is turning back to its original producer. In our study, we use the term "reverse logistics" to refer to the physical collection and distribution planning from consumers to recyclers of textile and clothing. Another relative term which should be distinguished from reverse logistics and will not be studied in our research is "green logistics" or "ecological logistics". It refers to the activities for minimizing the ecological impact of logistics operations. Such activities include measuring and reducing the ecological impact of transportation and ISO 14000 certification and reduction of energy usage (Rogers and Tibben-Lembke, 1998). Green reverse logistics approach can promote valuable economic and environmental benefits to the society, which help saving unnecessary cost and GHG emissions.

\subsection{Drivers and barriers for implementing reverse logistics}

Previous studies have identified the main drivers and barriers that drive and obstruct the firms for RL implementation. There are three types of initiatives that motivate reverse flows (Murphy, 1986): a) customer-based, due to the product returns, b) industry-based, interested in recycling and re-manufacturing and c) government-based, aims at promoting legal disposal and government regulation for environmental issues (Rogers and Tibben-Lembke, 1998). In fact, used textile collection and recovery can be customer-based focusing on the good-well either 


\section{Líterature Review}

socially or environmentally, industry-based focusing on the economic value of materials, charity-based focusing on social well-being, and /or governmentbased, focusing on material efficiency and waste reduction. Rogers and TibbenLembke (1998) argued that there are many challenges that hinder companies to adopt RL channel, such as system cost, the need for good monitoring and information system, lack of feasibility study and the difficulty of managing the reverse distribution. In this study, we identify the drivers and barriers for having a national textile recovery channel for textile and clothing particularly.

\subsection{Reverse Logistics Networks Design}

Network design has a strategic implication for the firms and can play important role in improving the supply chain performance including the reverse logistics practices. Network design problems can support facility location decisions for forward supply chain for production, warehouse and distribution as well as the reverse supply chain facilities for collection, sorting and recycling. By that, firms can maximize the value of recovered products and minimize the cost of the overall logistics system. In other words, they will be able to allocate their processes and warehouses in a cost-effective manner. (Fleischmann et al., 2003).

Forward and reverse logistics networks can be modelled using nodes and arcs. Nodes represents facilities that activities take place in while arcs represent the physical flow between them. The complexity of reverse logistics network design 
depends on the features and assumptions embedded on it. In other words, RL network design becomes more complex when considering additional forward/reverse activities, uncertainties, different planning horizons, multiitems flow, multi-sourcing facility, extra constraints and external factors.

Fleischmann et al. (1997) have done a systematic review to categorize the quantitative models proposed in RL issues by different authors into three main activities: Reverse distribution (RD), inventory control (IC), and production planning (PP). The RD has been defined as the physical transportation of used product from the end user to a producer. The RD could be performed by one of the following three channels: using the same traditional logistics channel; creating new reverse channel; or using both channels together. In 1975, Guiltinan and Nwokoye (cited in Fleischmann et al., 1997) identified four types of reverse channels according to the actors considered; making a decision for which channel we need to follow will raise set-up questions such as: who are the actors involved? Which activities have to be carried out and where? And what is the relation between the forward and reverse distribution channels? The authors then distinguish three network types, namely remanufacturing, recycling, and direct reuse networks. Fleischmann et al. (2003) refine this model by including ownership of the recovery process (original equipment manufacturer (OEM) versus third party) and recovery drivers (economic versus legislative) as additional explanatory variables. Based on this analysis, the paper suggests 


\section{Líterature Review}

distinguishing the following five network classes: (1) networks for mandated product take-back, (2) OEM networks for value added recovery, (3) dedicated remanufacturing networks, (4) recycling network for material recovery, and (5) networks for refillable containers. (Fleischmann et al., 2003)

Unlike for other industries such as electronics, batteries, and vehicles, reverse logistics network design development for textile recycling has not been studied yet. The facility location can be determined using facility location MILP model once the preferred network configuration of RL has been identified. Previous studies have addressed model development for electrical equipment in Greece (Georgiadis and Besiou, 2008), carpet industries in the US (Realff et al., 2004; Biehl et al., 2007), sand released from processing construction waste in The Netherlands (Barros et al., 1998), and defective and hazardous products (Jayaraman et al., 2003).

In this thesis proposal, mixed integer programming will be used to formulate our mathematical model proposal for textile recovery once we identify the main actors and flow of materials. The method has been widely used in the scientific literature for solving network design problems for forward and reverse distributions. Unlike forward logistics, the reverse flow does not have a clear defined path so that it may take several forms. Materials also differ in terms of re-usability and recyclability. 



\section{Chapter 3}

\section{OBJECTIVES AND}

\section{RESEARCH METHODOLOGY}

\subsection{Research Objectives}

Operations management research addresses issues relevant to both practitioners and academics to contribute to the field development and management science. There are different methodologies used in operations management research that have been briefly introduced in this chapter. The most dominant research methodology used in this dissertation is case study research. Case study research is a research that intends to capture complex issues using a single or collective case of the object of study (Stake, 1995). In this dissertation, I explore the current practices of post-consumer textile recovery in France and Germany accounting for qualitative case research method to address the following research questions:

1. What are the current practices of post-consumer textile recovery?

2. How can we improve the current reverse logistics activities and practices of post-consumer textile?

3. What are the challenges we face to promote sustainable textile recovery? 


\section{Chapter 3}

4. How to develop a circular textile industry in developed countries?

The first research question has been addressed by conducting case studies that examine the current practices of post-consumer textile recovery in France and Germany in Chapter 4. This will lead us to explore the subject in depth and to find answers to the following questions: What are the collection schemes and redistribution channels implemented currently for used clothing? Who are the current actors and what motivate fashion producers, charities, and recyclers to recover post-consumer textile? How do governments and municipalities manage the textile waste? What are the benefits that textile recovery gives? Then, a quantitative case study that evaluates the current logistics network in Paris, France is presented in chapter 5. Quantitative data analysis in addition to the qualitative analysis could further help to understand the case and justifies the problem. Mathematical programming approach is used to evaluate the current RL network. This RL model can be used by practitioners to solve simple collective location-allocation problem to assign a recycling facility for collected clothing bearing in mind the transportation cost and capacity constraints. The study is supplemented by a proposed model to facilitate better logistics network design that can be adopted by individual or collective frim to promote sustainable textile collection and recovery. The design can help practitioners to efficiently develop an extended reverse logistics network to open/close potential storage sites and recycling facilities based on the material flow from the origin to its market 


\section{Objectives and Research Methodology}

destination after recycling using mixed integer linear programming. The third and fourth research questions have been addressed in the discussion section in chapter 6 based on the examination of the current practices in France and Germany. The purpose of addressing these research questions is to make the logistics of the current post-consumer collection and recovery more efficient and sustainable, reducing the social and environmental impact of such practices.

\subsection{Research Approach}

This dissertation accounts for a qualitatively-driven mixed-methods research "QUAL-quan" to address various research questions related to the research problem. One of the main concern of qualitative researchers is how to rigorously conduct a qualitative research in OM. Qualitative research in OM should demonstrate high degree of rigor in order to be accepted as a scientific research and should stress the importance of validity and reliability (Yin, 2013; Miles et al., 2014). Conducting rigorous research has been significantly discussed and debated over the last decade by many management researchers (see Vermeulen, 2005; Flynn, 2008; Mentzer, 2008). They stressed that that developing relevant research should not come at the expense of rigor. In addition, regardless of how important the research method is, a clear demonstration of rigor is more important. The conventional criteria for evaluating methodological rigor are validity and reliability. Goffin et al. (2012) summarized all criteria introduced in the literature for evaluating methodological rigor. Qualitative researchers must 


\section{Chapter 3}

demonstrate a convincing trail of evidence which is considered the central challenge to conduct such research. On the other hand, quantitative methods can aid researchers to capture empirical data and gains scientific relevance. As a mean for quantitative analysis, mathematical modelling and simulation are widely used in operations management research to support decision making in various areas including reverse logistics network design. Dekker et al. (2004) highlighted important areas in the supply chain management that have been mathematically modelled by academics. They refer to the investigated areas as a long term (strategic) and shorter-term (tactical or operational) decisions. The network design problems belong to the strategic distribution decisions. Transportation, on the other hand, is considered a shorter-term distribution decision. Numerous transportation models have been developed to support mainly fleet management, route planning and vehicle scheduling. Production planning and control is another supply chain area that has been mathematically analyzed in different decision horizons. Capacity planning, inventory location and risk pooling are among the recognized issues of strategic horizon. Whereas lot sizing, safety stock and production scheduling have been investigated to support shorter-term decisions. Researchers recently put further attention on capturing the complexities arise from the interaction between different functional areas (Dekker et al., 2004). Such complexity and interaction can be found also in reverse logistics studies. 


\section{Objectives and Research Methodology}

\subsection{Research Methodologies in Operations Management}

Conducting a scientific research in operations management $(\mathrm{OM})$ requires considerable understanding of the existing methodologies to successfully align the purpose of the study to the result and contribution that need to be reached. Therefore, in this section, different research methodologies will be presented in a concise manner to clearly recognize which methodologies are more suitable for this research. A critical attribute for evaluating the research findings derived from the conducted study is that the value of the findings must be seen along with the way they were derived (Karlsson, 2009). A good scientific research project is characterized by (Forza, 2002):

1- Purposiveness: the objective of the project is well defined.

2- Rigor: founded by a good theoretical base and a sound methodological design.

3- Testability: hypothesis should be derived clearly from the data.

4- Replicability: results will be the same when repeating the study again and again.

5- Precision and confidence: the probability of having an error in our estimation is small and the findings match to the reality.

Research in operations management might consist of qualitative or/and quantitative studies. Qualitative and quantitative methods have different purposes and differ based on how data is collected and analyzed, and they are commensurate with each other. For instance, case research often involves both qualitative and quantitative methods in the research design. From a technical 


\section{Chapter 3}

perspective, there is no clear dichotomy between qualitative and quantitative methods and our method selection should rely on the research questions that we want to investigate (Karlsson, 2009). Although qualitative research is limited in the management science literature and more studies are needed (Näslund, 2002; Voss et al., 2002), balancing between quantitative and qualitative approaches would help the researcher to gain more knowledge in the field. Thus, this thesis is conducted using qualitative and quantitative methods to enrich the knowledge and skills from using different approaches. In general, the most common methods used in operations management research are survey, case study, action research and modeling and simulation. Hence, we briefly summarize and highlight the purpose of each method below.

\subsubsection{Survey research}

The purpose of survey research can be exploratory, descriptive, or confirmatory (theory testing). Throughout the study period, several unstructured interviews have been conducted to explore new information that experts in the textile recycling sector possess. The interviews have been conducted personally at the textile sector's panel discussion "Fachtagung der Gemeinschaft für textile Zukunft" that took place in Germany in November 2017 and some have been conducted through organized telephone calls with textile recycling firms' personnel. Survey research normally encloses a structured survey, where the size of the sample survey could vary based on the researcher 


\section{Objectives and Research Methodology}

approach and the information need to be revealed. However, researchers could also follow a relatively systematic approach to collect qualitative or quantitative information from individuals, households, or larger organized entities through mailed questionnaires, telephone calls, personal interview, etc. (Rossi et al., 1983)

\subsubsection{Case research}

Case research has its roots in the field of social science and it is widely used in different fields in management science. Case study is the most common method in qualitative research, but it gets sometimes applied with insufficient rigor (Seuring, 2008). Rigor should be involved in research design, data collection and analysis while conducting a qualitative research to ensure validity and reliability on the findings obtained (Voss et al., 2002; Seuring, 2008; Yin, 2013). Case research is powerful method in operations management, especially in the development of new knowledge, because of its meaningful and natural narrative (Voss et al., 2002). It might consist of one or more case studies to answer what, why, and how questions regardless of the complexity of the phenomenon that has been studied (Voss et al., 2002; Yin, 2013). Therefore, case research has been adopted in this thesis as the main research methodology, which its main research questions start with "what" questions, to allow for explicit exploration of the field as well as identifying challenges and new tools that impede progress to promote sustainable practices. 


\section{Chapter 3}

A case represents an object to be studied for particular reasons. In section 3.1, the reasons have been stated as questions that need to be answered. According to Stake (1995), the design of the case research differs based on the purpose of study. Hence, the case research could be intrinsic or instrumental case. The intrinsic case helps in understanding the particulars of a single case while the instrumental case can be used to provide further insights on a specific issue or to refine existing theory. This dissertation has been designed to account for a collective instrumental case to advance our understanding of the sustainable collection and recovery of post-consumer textile and clothing and its interaction with the European circular economy transition. The cases have been selected to examine the difference of the textile channels recovered in Germany (extreme case) and France (certain criteria). German has been considered as an extreme case because it collects and recovers post-consumer textile and clothing more than other countries. France, on the other hand, has been selected based on certain criteria such as of having a national textile recovery program and the use of extended producer responsibility policy. So far, France is the only country that meets these criteria. 


\section{Objectives and Research Methodology}

\subsubsection{Action research}

Action research is a generic term that covers different forms of action-oriented research. The purpose of doing action research is to take an action as well as creating knowledge or theory about that action (Coughlan and Coghlan, 2002). Action research is appropriate when we want to understand and describe how and why certain actions change or improve working aspects of the system. Since this research is not answering how and why questions, action research methodology has been excluded from this study.

\subsubsection{Modeling and simulation}

Modeling and simulation research is quantitative in nature. Initially, modeling was used towards solving real-life problems in OM rather than towards contributing to scientific knowledge. Recently, modeling and simulation research is oriented to develop descriptive and predictive theory regarding operational processes. Models are abstractions from the reality do not represent a detailed and complete reality (Bertrand and Fransoo, 2002).

There are many modelling techniques widely used in operations management literature, one of which is mathematical programming. The goal of mathematical programming is basically to optimize a specified objective function subject to restricted constraints (Geoffrion, 1976). However, the reason behind this is to develop insights into system behavior to help to develop effective plans and decisions. Adopting the modelling approach in this thesis helps us to assess the current practices of textile recovery and to drive a modelling solution for 


\section{Chapter 3}

researchers and practitioners using mathematical programming to help reaching efficient reverse logistics network design. Mathematical modeling approach is widely used when solving logistics network design problems. Thus, in this part, we will formulate and analyze different reverse logistics networks using linear programming (LP). We later extend our model using mixed integer linear programming (MILP) to formulate richer model that covers more parameters. MILP is a mathematical programming method that is vastly used by operation researchers and it is the most popular method found in commercial use (Ballou, 2004). It is also considered one of the most flexible techniques for designing logistics networks especially when formulating a new model. We turn this mathematical model to the programming model that can be read and solved by Python computer package. Several commercial computer packages can be found to solve optimization problems in Python such as Gurobi and Cplex, but we use a free solver package for solving our models using an open-source solver called “GLPK”.

\subsection{Research Tools}

\subsubsection{Atlas.ti}

Atlas.ti is a commercial computer tool to help us collecting, managing and coding qualitative data. It is used as analytical and visualization tool that may open new interpretative views on the investigated material. It has been widely used by researchers and practitioners coming from a wide variety of scientific fields including arts, anthropology, engineering, economics and others. In my 


\section{Objectives and Research Methodology}

research, I am using Atlas.ti to keep track of all of my notes, annotations and codes for all of my references. (http://atlasti.com)

\subsubsection{Python}

Python is one of the most popular programming languages among scientists of a wide variety of disciplines. It is developed under the open source initiative (OSI) and is approved for open source license, making it freely usable and distributable, even for commercial use. It is a high-level interpreted language meaning that most of its implementations execute instructions directly, without previously compiling a program into machine-language instructions. One of the advantages for using Python is that there are several packages available that include a wide range of pre-defined functions to help us analyzing structured and unstructured data easily and efficiently. Formulating my model, I have worked with Pyomo package, which I believe is more user-friendly than "Pulp" and other python packages.

\subsection{Research Framework}

Considering the research objectives, this study will be based on mixed research methodologies starting with qualitative case studies, passing through quantitative modeling, and ending up with qualitative findings. The first part of the study aims to characterize the reverse logistics networks utilized for postconsumer textile recovery in Europe using the framework developed by (de Brito and Dekker, 2002). The objective is to answer the first research question which leads us to understand: How and why the recovery of textile and clothing is 


\section{Chapter 3}

performed, what activities and facilities are devoted for the reverse logistics (RL) program, and what benefits we can get from having this textile recovered. For that, various case studies have been developed to examine the post-consumer textile recovery from different perspectives. The first case study shows a textile recovery practices at a national level. So, France has been selected since it is the only country that has a national legal framework for textile recovery. The second case study represents orientation for the textile recovery in Germany, where textile collection and recycling rates have reached its highest level. We further examine the textile recycling activities for SOEX Group, the largest textile recycler in Germany to add another individual business perspective.

The second part of the study aims to use the results obtained from the case studies to discuss the limitations of current practices using a mathematical programming. Mathematical programming helps us to optimize the reverse logistics network to minimize the transportation cost as well as freight's carbon emissions. Beginning with a linear programming modelling, despite its simplicity, the solution of the model provides valuable insight for the potential transportation cost and emissions savings that we can achieve when developing a central reverse logistics network design nationally. For further reduction, we introduce a complex mixed integer linear model that help collective or individual recycling organizations to develop efficient reverse logistics network based on potential facilities and markets. The model can be used widely for different 


\section{Objectives and Research Methodology}

sectors to make strategic decisions on the reverse logistics network in order to maximize the value of recovered products and to minimize the cost of the overall system. In other words, the model helps to locate different activities to select costeffective means of transportation.

In the third stage, new study is developed to discuss the challenges that need to be addressed in order to promote efficient national reverse logistics network design. The study is presented in the discussion section for this thesis and will pack up the thesis contribution with it. 



\section{Chapter 4}

\section{QUALITATIVE STUDIES}

\subsection{Post-Consumer Textile Recovery in France}

\subsubsection{Background on solid waste management in France}

France has an ambitious target for waste collection, but it is struggling to achieve the European Commission target, that is 50\% recovery of solid waste. It has the $3^{\text {rd }}$ largest economy and the largest surface area in the European Union (EU), with more than 67 million habitants (Eurostat, 2017). The National Program for Waste Prevention 2014-2020 was adopted in France on 18 August 2014 (ADEME, 2016). Many provisions have been made for preventing the waste,

including the Law of Energy Transition for Green Growth (LTCV), law Consumption, Food Waste Law, and Biodiversity Law. The program indicates some quantitative objectives on the prevention of waste until 2020, without reporting particular waste prevention objectives for textiles. The Law of Energy Transition for the Green Growth has strengthened some objectives and has reduced the amount of all household and economic waste collected by public waste management services by $10 \%$ per capita in 2020 compared with 2010 


\section{Chapter 4}

(European Environmental Agency, 2016). The waste has been categorized and prioritized into three levels to focus on the waste streams with the greatest potential for reduction. Highest priority waste streams are food waste, construction and demolition waste, chemicals, batteries, electrical and electronic equipment, furniture and paper. The second highest priority waste are household packaging, plastics, metals, vehicles and textiles. The third category includes organic materials, plants, woods, and glass (Ministère de l'Écologie, du Développement durable et de l'Énergie, 2014).

New environmental policies in France are discussed by the Council of Ministers, the only formal meeting for governmental members. The Council of Ministers plays important role in defining the political directions of the government. It is chaired by the President of the Republic (Head of States) and brings together the Prime Minister and all government ministers. The development and implementation of political and environmental policies are discussed in the meeting that leads to make important decisions with the President of the Republic. The meeting is divided into three parts: the first part is devoted to a general discussion about bills, orders, or decrees for which a deliberation of the council is necessary; the second part concerns the individual decisions, mainly the nominations of the senior officials; and the last part is generally devoted to the presentation of a minister (who can present the progress of a reform) or an intervention of the president (who can seek the opinion of the 


\section{Qualitative Studies}

government on a particular point). While the Prime Minister decides which policies should be undertaken nationally, the Council of Ministers should discuss the practical steps to achieve the national goals. At the end of the Council of Ministers, the Secretary General of the Government drafts a record of decisions reporting and attesting to decisions taken. The General Secretariat of the Government writes a complete report of the deliberations. A press release is then prepared for informing the public. (Gouvernement.fr, 2016)

The Prefect or "Préfets" in France is the senior civil servant exercising important functions in the state administration, whose existence and role are defined by the Constitution. Since 1982, the territorial administration has been divided between authorities and state services to run by the prefects. Today, the prefect represents the President of the Republic at departmental and regional levels, responsible for the implementation of all public policies. They thus embody the permanence and presence of the State throughout the territory and in all circumstances, guaranteeing the general interest and the great principles of public service. The Prefect is appointed directly by the President of the French Republic because it must have the full confidence of the President of the Republic.

The Ministry of Ecological and Solidarity Transition (Ministre d'État, ministre de la Transition écologique et solidaire), previously called the Ministry of Ecology, Sustainable Development and Energy (Ministère de l'écologie, du 


\section{Chapter 4}

développement durable et de l'énergie), prepares, implements and provides solutions for the Government's policy in areas related with environmental sustainability such as sustainable development, environment, green technologies, energy transition, prevention of natural and technological risks, industrial safety, transport and its infrastructure, air and water pollution, resource scarcity, and global warming. The ministry is involved in European and international climate negotiations. It drafts bills and decrees, enacts orders, and implements and enforces environmental law through the agencies under its authority. (https://www.ecologique-solidaire.gouv.fr)

\subsubsection{Drivers for the textile recovery}

France is the first and only country to legalize a take-back system for textile, linens and shoes. The Extended Producer Responsibility (EPR) policy for the aforementioned products has introduced by the Article L-541-10-3 of the Code de l'Environnement, which came into force on first of January 2007. Since that date, according to the new legislation, all legal entities presenting in the French market new textile apparel products, i.e. garments, footwear and household linen, are hold responsible for the recycling or proper disposal of the waste generated by those products. Those entities (which include manufacturers, importers and distributors) can accomplish this legal obligation through two distinct ways: either by financially contributing to an accredited Producer Responsibility Organization (PRO) or by setting-up an individual take-back program approved 


\section{Qualitative Studies}

by the French public authorities. Publication of the decree in the Journal Official specifying how to implement the law and the need of establishing ecoorganization, PRO, took place in June 2008.

Article L. 541-10-3 and R543-214 of the Code de l'Environnement

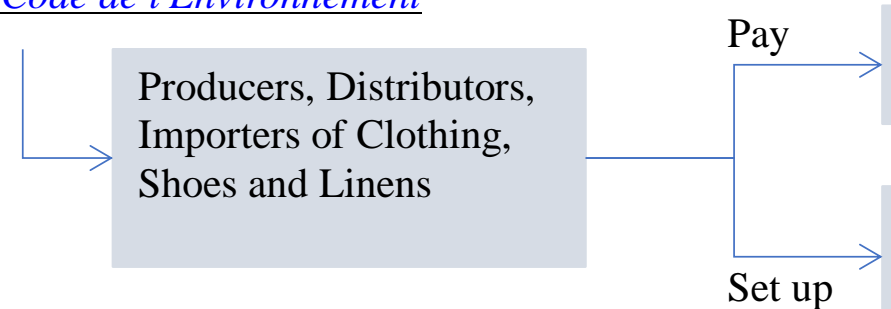
Accredited PRO

Approved Individual Recovery Program

Figure 4-1 EPR policy for textile, shoes \& linen in France

The authorized PRO must work in compliance with the provisions of the Authority specification to fulfill the following obligations. First, to support textile and clothing recovery and waste prevention. Second, to promote, through information, awareness raising and communication, the development of separate collection of TLC waste. Third, to contribute financially for sorting and recycling. Fourth, to investigate and support projects and research studies to improve the performance of this sector, including the development of new markets and the improvement of recovery operations for minimizing the system cost.

Therefore, a PRO for textile, footwear and linen was created in December 2008, Eco TLC (Eco-organisme du textile, du linge et de la chaussure), which is for the moment the only PRO accredited by the French public authorities to cover the sector. Eco TLC is a non-for-profit private company initially constituted by 29 associates (associés). The associates represent the whole textile value chain and 


\section{Chapter 4}

are organized in five "colleges": (a) general large retailers (e.g. Auchan, Carrefour, Monoprix); (b) fashion retailers (C\&A, Galeries Lafayette, Etam); (c) direct sales and mail/online retailers (Damart, Groupe 3SI); (d) manufacturers and wholesalers (LVMH, Cotonflor-linge du lit); (e) apparel industry associations (Federation Nationale de l'Habillement, Union des Industries Textile). The Board of Directors of Eco TLC is consisted of 12 representatives chosen among the associate companies. Apparel manufacturers, importers and distributors can register as members (adhérents) of Eco TLC in order to fulfill their EPR liability. Membership involves paying an annual contribution to Eco TLC, based on the last year's volume put on the market, and transferring the member companies' responsibility to the PRO. Currently, there are around 4967 members of Eco TLC represent $93 \%$ of the industry and they are listed in the PRO web site (http://www.EcoTLC.fr/).

The funds raised by members' contributions are used by Eco TLC for different purposes: covering the operating costs of the product recovery system; funding R\&D projects on the field of used apparel collection and recycling; and supporting awareness-raising campaigns organized by local authorities to encourage apparel waste sorting at household level.

The tariffs for members' contributions are calculated every year, depending on the previous year expenses. Members' contributions are received in the first quarter of the year $(n)$ and are based on the number of units (and their size) put 


\section{Qualitative Studies}

by each member company in the market during the year $(n-1)$. Tariffs consider four different sizes for garments and linen (very small, small, medium and large) and two sizes for footwear items (small and medium). The PRO incentivizes textile producers by reducing the annual tariff when they use recycled fibres made from pre-consumer or post-consumer textile, linen and shoes. Producers can benefit from the "Eco-Module (1) Tariff", which represents a 50\% discount over the normal tariff if their products have a proven minimum composition of $15 \%$ of post-consumer recycled fibers or materials (see Tariff in Table 4.1). They can also benefit from the "Eco-Module (2) Tariff", a 25\% discount over the normal tariff if their products have a proven minimum composition of $30 \%$ of preconsumer recycled fibers. To be eligible for Eco-Module tariff, the PRO examines supporting documents, provided by the main producer, that prove the type of recycled components, the origin of used material, and their proportion in the composition of the new products (Eco TLC 2016a). Member companies whose revenue is under $€ 750,000$ or sell less than 5,000 items in year ( $n-1)$ are entitled to contribute a fixed tariff of $€ 36$ plus VAT. (Eco TLC, 2016b) 
Table 4.1 Tariffs for 2016 members' contribution (n-1=2016)

Own development based on (Eco TLC, 2016b)

\begin{tabular}{|l|l|ccc|}
\hline \multirow{2}{*}{$\begin{array}{l}\text { Garments } \\
\text { \& Linen }\end{array}$} & \multirow{2}{*}{ Examples } & \multicolumn{3}{|c|}{ Tariff $(\boldsymbol{\epsilon})$} \\
\cline { 3 - 5 } & & Regular & Eco-module (1) & Eco-module (2) \\
\hline Very Small & Socks, kids' underwear & 0,00132 & 0,00066 & 0,00099 \\
\hline Small & Shirts, leggings, lingerie & 0,00528 & 0,00264 & 0,00396 \\
\hline Average & Pijamas, nightdress & 0,00791 & 0,00395 & 0,00593 \\
\hline Large & Adult's jacket, coat & 0,0528 & 0,0264 & 0,0369 \\
\hline Footwear & & & & \\
\hline Small & Slippers, mules & 0,00528 & 0,00264 & 0,00396 \\
\hline Average & Shoes, boots & 0,00791 & 0,00395 & 0,00593 \\
\hline
\end{tabular}

The Ministry of Ecology, Ministry of Industry, the Ministry for Local Government (interior and decentralization) and the ADEME are the main actors of national policies affecting the textile waste management. The main players involved in recovering used textile and clothing are: consumers who need to contribute and dispose their used textile and clothing in the specialized containers; local authorities, who raise awareness to their fellow citizens, coordinate the collection and incentivize enterprises for recovering used textile and clothing; the primary market (manufacturer, distributor or importer) who sell on the French market new clothing, linens or shoes; Collection agencies which manage and transport collected used textile and clothing in addition to providing drop-off collection points, door-to-door and surplus collection services; Secondary market which selects the "cream" of used textile and clothing and resell them to the shops of associations, thrift stores and recycling plants; 


\section{Qualitative Studies}

sorting industries which sort used textile and clothing and aim to maximize the recovery and meet the market demand by reusing and recycling; recyclers which transform un-wearable materials into secondary materials to be used for manufacturing new products; and eliminators which treat non-recoverable materials to be incinerated or landfilled (Figure 4-2). All players in the textile and clothing sector are linked by an integrated information system to monitor: the flow of products and materials; the financial flows; common interests to meet the challenges of sustainable development (environmental, economic and social); and the function and performance of the sector. In addition, many associations are working closely with local authorities to evaluate the current recovery activities of textile and clothing and drive up local issues to ensure and promote the best waste management at local and national level. There are general associations such as Association des Maires de France (AMF) and Assemblée des Communautés de France (AdCF); and especialized associations such as AMORCE National Association of communities, associations and companies for waste management, energy and heat networks. AMORCE currently represents 825 members (553 local authorities and 272 professionals) and is a key player in the management of waste for local and national authorities. There are also associations of consumers and environment protection that represent civil society and consumers to discuss social issues and increase people awareness for evolving professional practices and individual behaviors in waste management 
of used textile and clothing (e.g. France Nature Environment (FNE) and Zéro waste France).

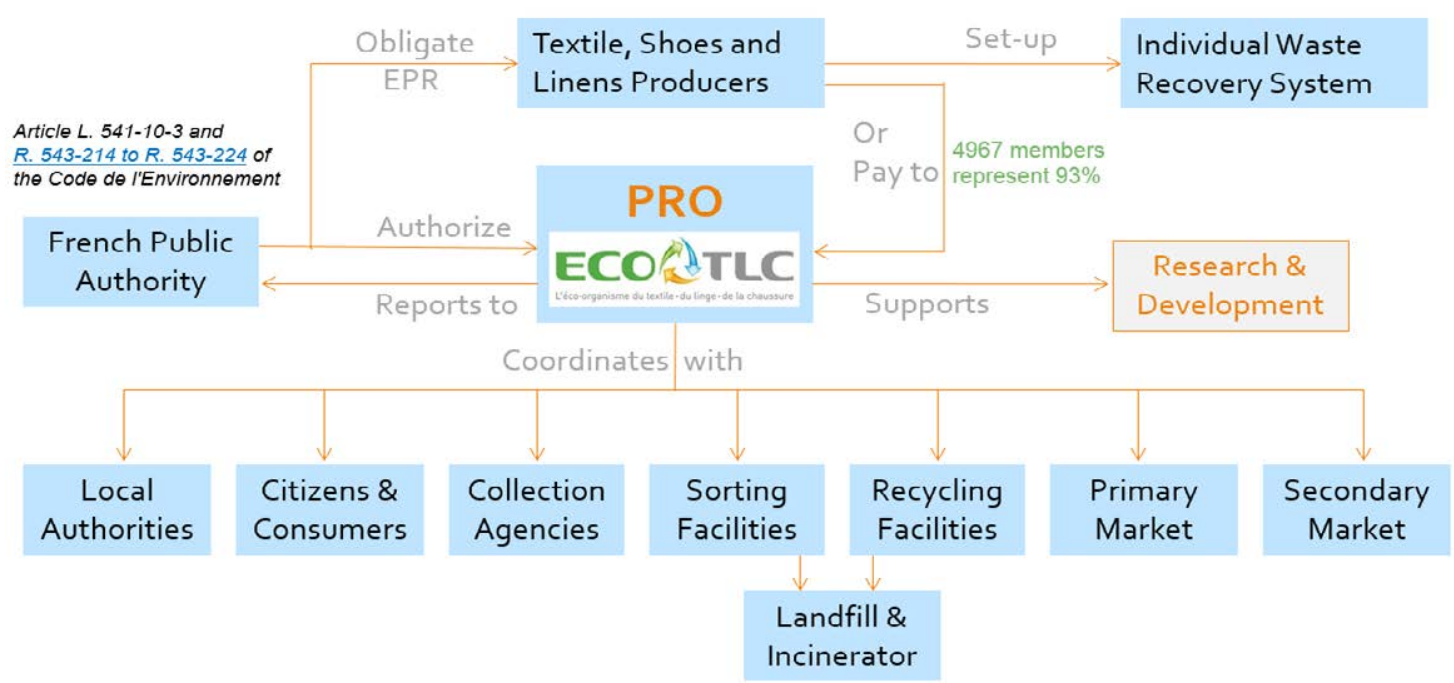

Figure 4-2 Stakeholders acting in the French textile recovery system

In 2012, 2400 million pieces were put on the market and 14 million Euros were collected from the members (an average of 0.05 euro per unit). This contribution was used and distributed as follow: 2 million euro (8\%) was paid for taxes, staff, offices, and outsourced services; 250,000 euro (2\%) was paid for research and development; 3 million euro (25\%) to cover collection and logistics services; and 9 million euro (65\%) was for sorting and recycling enterprises. (Tiard, 2013)

\subsubsection{Collection}

Every year, the amount of collected textile and footwear in France is increasing. In 2006, the amount of collected articles was 65,000 tonnes. In 2011, around 140,000 tonnes $(2 \mathrm{~kg} /$ person) of used textile were collected and it is estimated to reach 175,000 tonnes in 2015 (La Fédération de la Maille \& de la Lingerie, 2014). There are around 600,000 tonnes $(10 \mathrm{~kg} /$ person) of clothing $(80 \%)$, linen 


\section{Qualitative Studies}

$(8 \%)$ and footwear (12\%) are put into the French market every year (Tiard, 2013). France has set $50 \%$ (4.6 kg/person/year) as a collection target for clothing, linens, and footwear to be reached in 2019 as a part of the national waste prevention program of 2014 to 2020. Thus, every year more collection organizations and collection bins are put together in the process in the hope of achieving more collection (Figure 4-3). Presently, there are 150 collection operators representing more than 35,000 collection points as shown in Figure 4-4. Eco TLC pays for each collection point, Point d'Apport Volontaire (PAV), when reaches 2000 inhabitant coverage. The collection is financed by the resale market for second hand and recycling. After use, apparel can be dropped off either in stores (e.g. H\&M) or in special designated containers. Consumers can find the containers in the street and in recycling centers. Cleaned clothing should be separate than dirty one and both should be placed in a plastic bag of 50L size or smaller. The pair of shoes needs to be tied so that will not get separate during sorting. To help consumers locate the closest drop off place, Eco TLC has launched a mobile application and interactive website for this purpose as well as raising the customer awareness regarding the textile waste recycling. Used apparel can be collected door-to-door from partner charities or households. It has been reported that the volume collected through containers is about $46 \%$, whereas charities and household's collection represent $36 \%$ and 18\% respectively (La Fédération de la Maille \& de la Lingerie, 2014). All collected products are then transferred to sorting centers to 
where items will be examined and sorted according to their serviceability, quality and conditions.

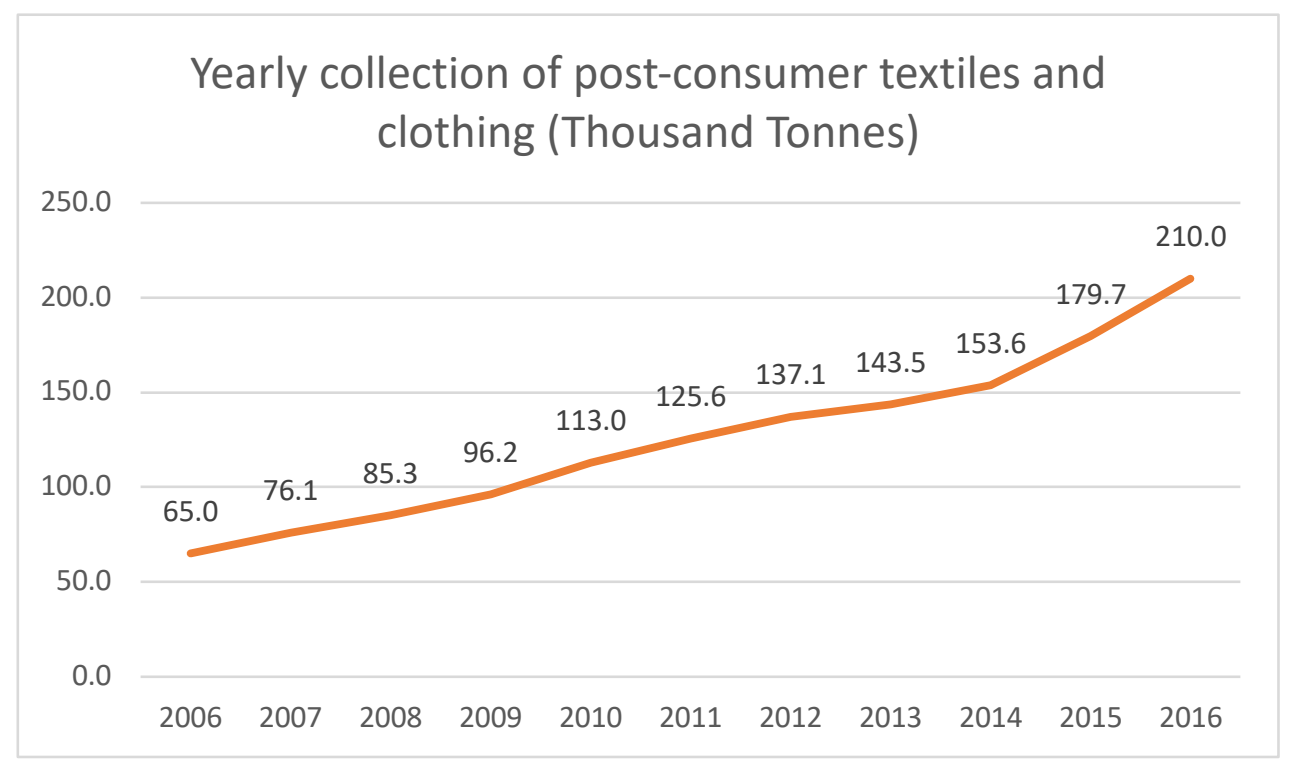

Figure 4-3 Annual increase in collection of textile and clothing in France

Own development based on (Eco TLC, 2016a)

The national territory is covered up by one voluntary contribution point (PAV) per 1840 habitants in 2015. Only twenty departments did not reach the level of $1 / 2000$ inhabitants. There is a target to increase the collection points to reach one per 1500 inhabitants to make it more convenient and accessible to the citizens who want to dispose their used textile and clothing. 


\section{Qualitative Studies}

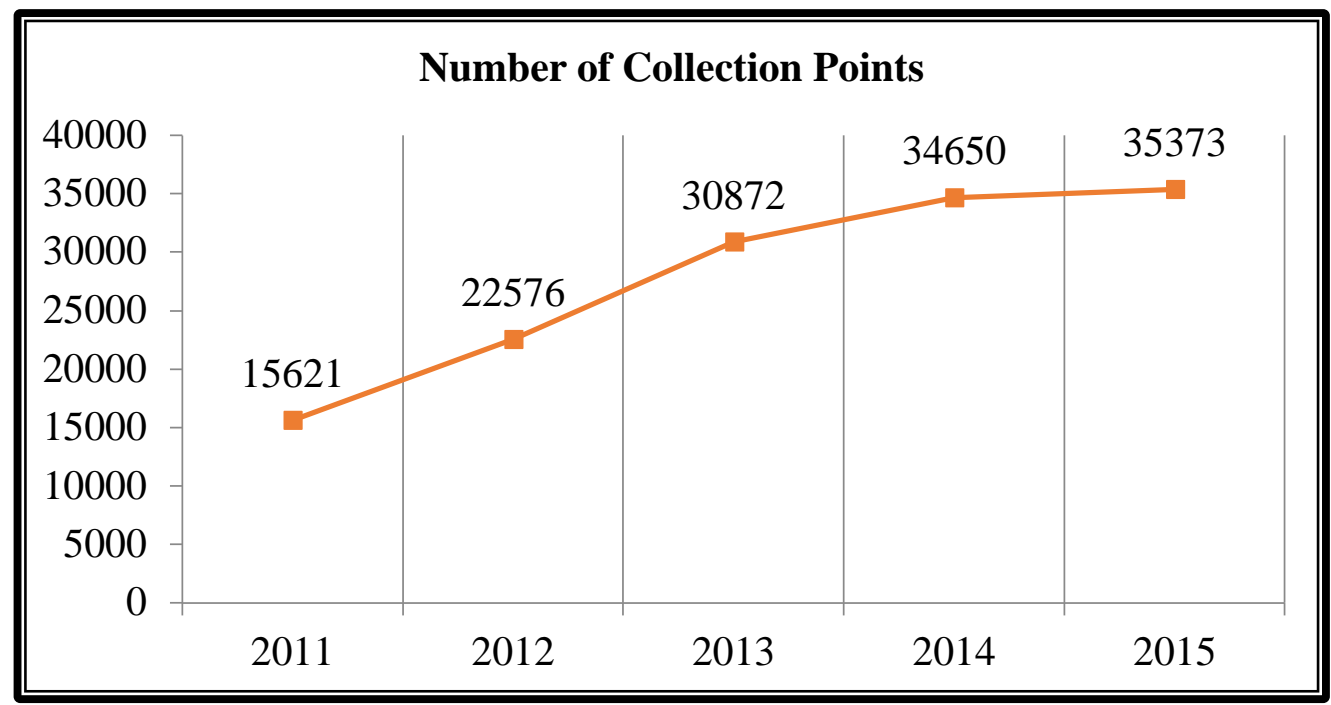

Figure 4-4 Number of collection points in France

Own development based on (Tiard, 2013)

Authorized collection points holders, "Voluntary Contribution Point Holder" (DPAV), persons or entities holding a voluntary contribution point (PAV) are easily allocated in the website of Eco TLC. Permission and authorization are required to be able to add a PAV on site. A "collection operator" is the agency which provides the pickup and logistics services to collect what is inside the PAV and deliver it to a sorting facility. It can also be "Holder of Voluntary Contribution Point". The DPAV and collection agencies gather various actors such as: associations, professional and non-professional sorting agencies. Holders of voluntary contribution points and logistics providers can collect used clothing using different collection schemes: Public or private clothing bins, charity collection, and/or door-to-door collection from houses or organizations. The majority of used clothing is being collected from public containers (Table $4.2)$. 
Table 4.2 Collection channels implemented in France and their performance

Source: (Eco TLC, 2015)

\begin{tabular}{|c|c|c|}
\hline Channels & Collection \% & Examples \\
\hline $\begin{array}{c}\text { Containers } \\
\text { accessible 24 hrs. }\end{array}$ & 69 & Curbside bins \\
\hline $\begin{array}{c}\text { Containers with a } \\
\text { limited access }\end{array}$ & 23.5 & $\begin{array}{c}\text { La Fédération Nationale de } \\
\text { l'Habillement and Union des } \\
\text { Industries Textile }\end{array}$ \\
\hline $\begin{array}{c}\text { Donation to } \\
\text { associates }\end{array}$ & 7 & $\begin{array}{c}\text { From Charities under the Social } \\
\text { Solidarity Economy }\end{array}$ \\
\hline Door-to-door & 0.5 & \\
\hline
\end{tabular}

The agreement of DPAV with Eco TLC allows them to be integrated into the recovery sector and be identified with other stakeholders and professionals to increase the traceability of each one. As a PRO, Eco TLC is responsible to provide the DPAV a free kit for standardized and customized system to monitor and locate their PAV in a geographical map that can be accessed by the public and local authorities. On the other hand, DPAVs are committed to: provide and update the geographical positions of theirs PAVs; declare the tonnage of collected textile and clothing and destinations so that traceability can be achieved to monitor the materials flow; and to use the common logo and symbols provided by Eco TLC to increase public awareness.

\subsubsection{Sorting}

Eco TLC is financially supporting sorting and recycling businesses fulfilling the required standard and work conditions. In 2014, 60 European sorting 


\section{Qualitative Studies}

companies were involved (45 facilities were French). Those enterprises should report to Eco TLC the amount collected and how has been reutilized and recovered. Sorting is very critical phase and it requires trained persons because it is done manually, and it is where decision needs to be made to choose the items destiny. The first stage of sorting will separate the re-wearable clothing and shoes and re-useable linens manually from the ones which need further treatment. So that the re-useable products will be either locally re-sold in second-hand shops or re-sold and exported to other countries (mainly developing countries). Part of "good-condition" clothing is given to the people in need or sold at a low price while the remaining is sold to different traders. The second stage will involve removing the hard particles from the products and resorting according to the fiber length, color and quality. In fact, $60 \%$ of used articles end up for "re-wear", $30 \%$ are for "recycling", $5 \%$ are for landfilling, and 5\% are for incinerating and energy production. (Tiard, 2013)

Eco TLC provides financial support to sorting operators ( $€ 65 /$ ton for material recovery, $€ 20$ /ton for energy recovery) when they comply certain conditions (Table 4.3) to enable them to: improve their performance; increase their sorting capacity; and optimize the sorting and recycling output. When efforts are made to increase the sorting capacity as well as hiring workers who have difficulty finding jobs, additional supports of $50 €$ to $125 €$ per ton will be applied (Table 4.4). It has built a strong product management system to trace all actors in the 
process to measure and monitor the collected textile and clothing flow from each PAV up to the final destination described by type of recovery and disposal, by country and by customers.

Table 4.3 Sorting and recycling performance required for receiving financial support from Eco TLC

Source: (Eco TLC, 2015)

\begin{tabular}{|l|}
\hline Sorting Performance Required \\
\hline Material recovery rate $>90 \%$ \\
\hline Recycling rate (unraveling or wiping) $>20 \%$ \\
\hline Elimination rate without energy recovery $<5 \%$ \\
\hline
\end{tabular}

Clothing is sorted into different categories to be re-used for different purposes: The cream of the material "high quality" will be re-used and sold in second hand market in France or internationally; lower quality clothing will be re-used and sold in lower class market; Unusable clothing will be recycled to produce cleaning cloth or other materials used in different industries; and the remaining materials will be disposed in landfill or incinerator.

Table 4.4 Sorting agencies qualifications for receiving financial support from Eco TLC

Source: (Eco TLC, 2015)

\begin{tabular}{|c|l|}
\hline $\begin{array}{c}\text { Financial } \\
\text { support }\end{array}$ & \multicolumn{1}{c|}{ Qualifications } \\
\hline \multirow{2}{*}{$\begin{array}{c}(€ 65 / \text { tonne) for } \\
\text { material } \\
\text { recovery }\end{array}$} & Being a separate legal entity \\
\cline { 2 - 2 } $\begin{array}{c}(€ 20 / \text { tonne) for } \\
\text { energy recovery }\end{array}$ & $\begin{array}{l}\text { Respect la réglementation en matière de protection de } \\
\text { l'environnement (ICPE in France })\end{array}$ \\
\cline { 2 - 3 } & $\begin{array}{l}\text { Ensure traceability in upstream (including collection) and } \\
\text { downstream (including export) of the sorted materials }\end{array}$ \\
\hline $\begin{array}{c}50 \text { to } € 125 \\
\text { per tonne }\end{array}$ & Ensure financial transparency of its accounts \\
\cline { 2 - 3 } & Efforts are made to increase the sorting capacity \\
\hline
\end{tabular}




\section{Qualitative Studies}

\subsubsection{Recycling and Re-distribution}

Mechanical recycling is widely used in France. Recycling of textile includes one of the following different processes: unraveling, grinding, defibrating, and cutting. Any recycling operation requires first removal of hard particles like buttons, zippers and rivets. The most common processes are unraveling and cutting where the outcome for unraveling can be nonwoven fabric, flock and new yarn and for the cutting are the rags (Table 4.5) (Tiard, 2013). The market of the wiping cloths (rags) is important since 20,000 tons per year are produced in France. Also, clothes are cut into coupons to be reused as a patchwork to apparel and furniture industries. The grinding operation is used to produce short fibers or powders that can be used in plastic industry. Defibrating process is still under development to increase the fiber that can be rewoven into new textile. The overall rate of textile and clothing recovery in 2013 reached $94 \%$ on average and the reutilization of the recovery is shown in Table 4.6 (Eco TLC, 2015).

Table 4.5 The share of unraveling and cutting processes and their market locations in 2013

Source: (Eco TLC, 2015)

\begin{tabular}{|c|c|c|c|c|}
\hline \multirow{2}{*}{$\begin{array}{c}\text { Recycling } \\
\text { process }\end{array}$} & \multirow{2}{*}{ Amount \% } & \multicolumn{3}{|c|}{ Market } \\
\cline { 3 - 5 } & & In France \% & In Europe \% & Outside Europe \% \\
\hline Unraveling & 65 & 31 & 41 & 28 \\
\hline Cutting & 30 & 44 & 38 & 18 \\
\hline
\end{tabular}


Table 4.6 The share of each category and its market location from the total textile collected in 2013

Source: (Eco TLC, 2015)

\begin{tabular}{|c|c|c|c|c|}
\hline \multirow{2}{*}{ Category } & \multirow{2}{*}{ Amount $\%$} & \multicolumn{3}{|c|}{ Market } \\
\cline { 3 - 5 } & & In France $\%$ & In Europe \% & Outside Europe \% \\
\hline Re-wear & 61 & 10 & 13 & 77 \\
\hline Recycling & 33 & 37.5 & 39.5 & 23 \\
\hline Elimination & 6 & NA & NA & NA \\
\hline
\end{tabular}

\subsection{Post-Consumer Textile Recovery in Germany}

\subsubsection{Background on solid waste management in Germany}

Germany is the one of the world leaders in recycling solid waste (Eurostat, 2015). It is the most populous member state, with more than 82,8 habitants, and it has the largest national economy in Europe. Germany's waste recovery rates are the highest in the world in term of collection per inhabitant. The total waste recovered generates an annual turnover of 50 billion Euros (Wrap, 2012). Germany is the one of the world leaders in recycling solid waste (Eurostat, 2015). Germany recycled more than 45\% of the overall solid waste in 2015 with almost zero landfilling (see Figure 4-5). German authorities have realized that waste is a useful source of raw materials and energy in early days (Nassour et al., 2017) as materials such as metals, glass, and textiles were collected before the modern closed cycle policy. Households, public, and private organizations should sort their wastes based on their material category. Thus, materials such as glass, paper, packaging, metals, and textile have specific containers, that each has its independent collection channel. Textile is regarded as recyclable material, so it 


\section{Qualitative Studies}

can't be disposed in the "refuse" container except if it is dirty. Today, 14 percent of the raw materials in German industry are recovered waste (Nelles et al. 2016).

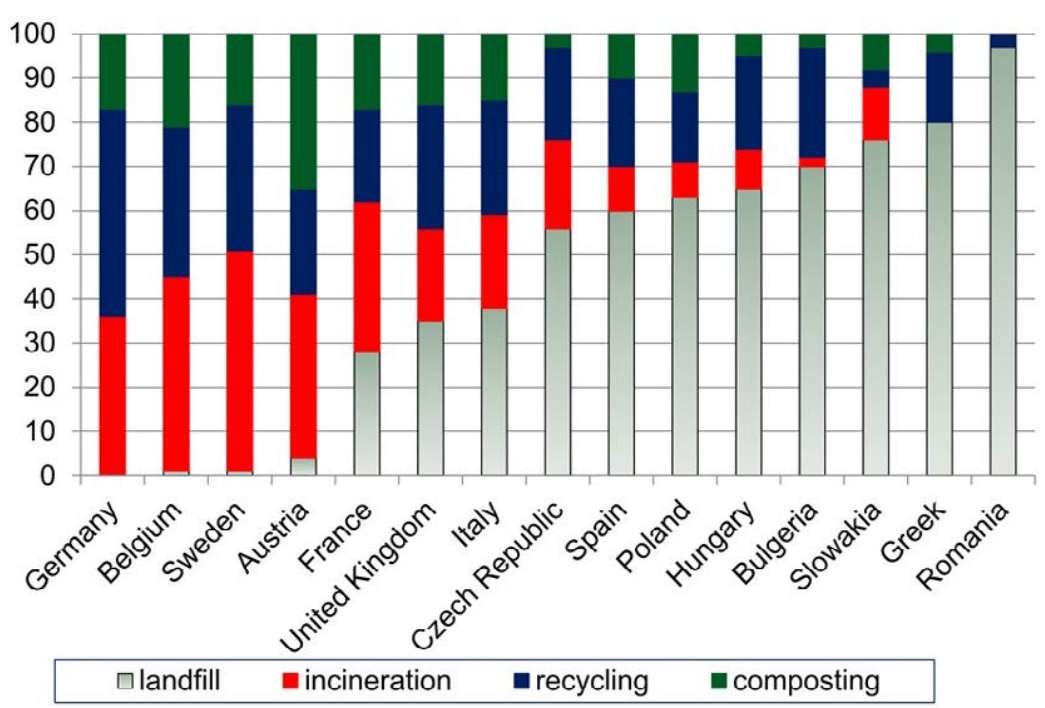

Figure 4-5 Municipal solid waste treatment (in \%) in selected EU countries Source: (Eurostat, 2015)

Germany's Waste Management Act (KrWG), effective in June 2012, transposes the European Directive 2008/98/EC into the German law. The Act is intended to tighten resource, climate and environmental protection regulations (see Article 1 of the Act). The key to the Waste Management Act is the implementation of the five-stage waste hierarchy: waste prevention, reuse, recycling, other utilization and waste disposal. The best option with regard to environmental protection has always been a priority, even if technical, economic and social aspects are taken into account. This ensures a consistent focus on waste prevention and recycling.

The collection of domestic waste varies across the member states. Domestic wastes are the wastes that people generates as a result of everyday use and 


\section{Chapter 4}

consumption. Domestic wastes can be generated in houses, public or private institutions, schools, commercial offices or industries. They include waste such as food, packages, papers, electric devices, batteries and used clothing. Germany relies on a broad range of container systems for source separation of various types of waste. Different collection systems to collect these products are observed. For instance, waste paper is collected either using private pick-up system known as "curbside collection" that covers almost all houses, offices, institutions, and industries or using public drop-off system by placing large containers accessible to the public in dispersed locations. The real waste is the residual waste which is the waste that is non-recyclable and non-separable. It is mainly collected by curbside grey containers that have different sizes depending on the number of persons that are using. Other curbside containers for organic waste, papers, and packaging materials are placed for collecting each type of material separately. Local authorities distribute and/or publish online the collection schedule and information as to which types of waste can be deposited in which type of container (waste ABCs). Such waste collection procedures are governed by local waste ordinances, which stipulate waste collection charges.

In managing industrial waste, the Act dictates extended producer responsibility (EPR) to ensure that potential waste material is reduced at the source. The EPR describes the legal obligation of manufacturers to be responsible for their products throughout their life cycles and after the end of their service 


\section{Qualitative Studies}

lives. Industrial waste generated during production are managed by the producer. Usually, they are either recycled by the manufacturer if possible, or they are disposed of by an authorized third party. Although the Act does not contain any provisions specifically regarding the handling of textile waste, the systems being used in handling both consumer and industrial waste materials included in the Act have proven to be equally suitable for the processes involved in the collection, sorting, and recovery of textile waste (United Nations Waste Report on Germany, 2010). The Act is enforced by the Federal Environmental Agency known as Umweltbundesamt (UBA) and it provides mandatory separate collection of five different classes of waste - paper, plastic, glass, metals, and biowaste.

Germany is also the world leader of textile collection per person per year (WRAP, 2012). The collection practices are existed since many decades ago collaborating with charities, churches, and commercial enterprises. The waste hierarchy of prevent, recover, and dispose was introduced and recognized for different products, including textile, in the 80s decade, under the Closed Substance Cycle and Waste Management Act, which came into force in 1996. According to this Act, owners and producers of specific products are responsible for waste avoidance, recovery, and disposal. However, clothing and textile producers not forced by the legislation yet. Thus, private organizations, charities, 


\section{Chapter 4}

and municipalities are the main actors for collecting used clothing, which add social, economic, and environmental benefits for them (Figure 4-6).

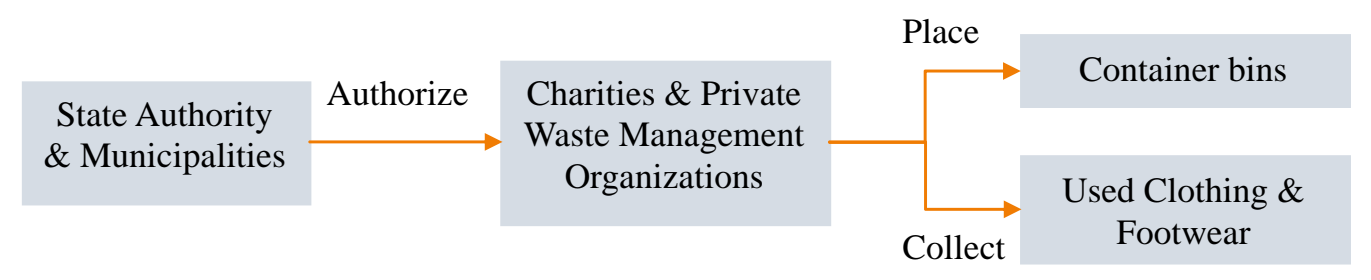

Figure 4-6 Authorization for textile collection in Germany

\subsubsection{Perception of German consumers on used textile and clothing}

The amount of textile collected from households in 2013 in Germany exceeds one million tonnes (Fachverband Textilrecycling, 2015). According to the report provided by the trade association of textile recycling in Germany, the amount of used textile collected in Germany accounts for $75 \%$ of the households' clothing consumption. The consumer study has focused on the German consumer behavior towards used textile and clothing and has revealed that 99 percent of the German private households do not treat used textile as a waste. Hence, $88 \%$ of them mentioned that this would lead to social benefits through supporting charities and people in need, and $54 \%$ believe that used textile sorting and recycling can help protecting the environment. The study has also reported the amount of textile collected and recycled for 2007 and 2013 (as shown in Table 4.7). 


\section{Qualitative Studies}

Table 4.7 Textile collection and recycling in Germany in 2007 and 2013

Own development based on the report provided by (Fachverband Textilrecycling, 2015)

\begin{tabular}{|c|c|c|c|c|c|}
\hline & & \multicolumn{2}{|c|}{2007} & \multicolumn{2}{|c|}{2013} \\
\hline & & $\%$ & {$[\mathbf{t}]$} & $\%$ & {$[\mathbf{t}]$} \\
\hline & Domestic market & - & $1,126,000$ & - & $1,347,457$ \\
\hline & Collection volume & 67 & 750,000 & 75 & $1,010,988$ \\
\hline \multirow{3}{*}{$\begin{array}{c}\text { Collection } \\
\text { channels }\end{array}$} & Container collection & 80 & 600,000 & 88 & 889,669 \\
\hline & Street collection & 20 & 150,000 & 9 & 90,989 \\
\hline & Others & - & - & 3 & 30,330 \\
\hline \multirow{5}{*}{$\begin{array}{l}\text { Recycling } \\
\text { channels }\end{array}$} & Reuse (Second-hand) & 43 & 322.5 & $54(66)$ & $\begin{array}{r}545.934 \\
(667.252)\end{array}$ \\
\hline & Recycle (Cleaning rag) & 16 & 120 & $21(16)$ & $\begin{array}{c}212.307 \\
(161.758)\end{array}$ \\
\hline & $\begin{array}{l}\text { Other Recycling } \\
\text { (Insulations and thermal } \\
\text { recovery) }\end{array}$ & 31 & 232.5 & $23(16)$ & $\begin{array}{c}232.527 \\
(161.758)\end{array}$ \\
\hline & Waste & 10 & 75 & $2(12)$ & 20.22 \\
\hline & Recycling rate & 90 & - & 98 & - \\
\hline
\end{tabular}

\subsection{SOEX Group: Collection and recycling of post-consumer textile and clothing}

In this study, a commercial enterprise in Germany, SOEX Group, is investigated because of their innovative partnerships programs for textile recovery. The company is certified as a specialist disposal company for the storage and treatment of waste textile. It was established in 1977 as a private company intending to become a global market leader in collecting, marketing, re-use and recycling of used textile. SOEX currently employs 2000 people working worldwide and exports used textile to around 90 countries in Asia, Africa, Europe, and North and South America. 


\section{Chapter 4}

SOEX Group owns two sorting and recycling plants, one in Germany and the other in the United Sates. The Wolfen plant in Germany can hold up to 3500 unsorted goods and 1500 sorted goods. The plants store, sort, and recycle the collected materials redistribute the processed items locally or internationally. Cleaning cloth is produced in-house and is marketed via their wholesaler IMHANEX GmbH in Salzgitter. The company also has many subsidiaries that are specialized in materials collection from charitable and commercial organizations such as EFIBA and Retextil in Germany and the European Recycling Company (ERC) in the UK. In addition, it owns many stores “Modemarkt Freestyle GmbH" in Hamburg, Munich and Berlin to sell second hand clothing and trendy vintage fashion.

A new subsidiary was founded in 2009 called "I:CO" which stands for $\mathrm{I}$ :Collect. Its role is to establish partner agreement with fashion retailers to support store collection of clothing (Figure 4-7). Every year more partners are involved in the take-back agreement. Presently, their partners are ADLER Modemärkte AG, American Eagle Outfitters, Calzedonia, C\&A Netherlands, BLACKOUT, Bingo-Schuh-Discount, Bächli Bergsport, Forever 21, Reno Group GmbH, HEMTEX, H\&M, intimissimi, JACK \& JONES, Levi's in the U.S. and U.K., MAMMUT, MAX Shoes, Modehaus Hempel, Fabric Retail Global AB Weekday, name it, OVS, Oxylane, Paris Cencosud Chile, PUMA, Schuh-bi-Du, SPORT 2000 


\section{Qualitative Studies}

Deutschland GmbH, North Face VF Outdoor Inc., Transa Backpacking AG, Vögele-Shoes, Volcom, Columbia Sportswear, adidas, and pointer. (․:CO, 2015)

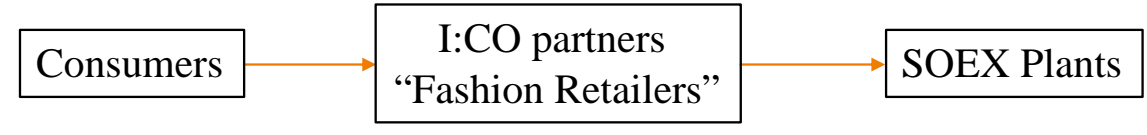

Figure 4-7 I:CO collection strategy

The I:CO collection program is marketing SOEX innovative textile sorting and recycling system for both fashion retailers and consumers. After signing the partnership agreement, fashion products including leather clothing and furs, underwear and socks, belts and bags, bed, table and household linen and cushions, will be collected in the designated I:CO boxes inside retailers' stores. Customers will obtain a shopping voucher reward depending on the total weight contributed. For each contributed kilo, the reward could be 5\% to $10 \%$ discount or five Euros discount when purchasing at the same store). The total capacity of $\mathrm{I}: \mathrm{CO}$ box is about $6 \mathrm{Kg}$. When the box is full, the store seals the shipping box and brings it to the store shipping area to be ready for pick-up. Then partner or $3^{\text {rd }}$ party collection agency will pick up the full boxes from the stores to deliver them to a consolidated warehouse to be transferred later to SOEXs' sorting facilities.

\subsubsection{Collection}

The unique collection system hold by SOEX Group has attracted shareholders, charities, and fashion retailers. SOEX aimed to collect more used apparel and decided to integrate with well-established logistics companies to handle the reverse distribution inside and outside of Germany. Many acquisitions and 
partnerships agreements took place with independent companies (e.g. EFIBA, Retextil, ERC, and NTA). Soex Group is collecting used clothing in different countries in Europe as well as in the United States (Figure 4-8). EFIBA collects mainly from charitable partners $(70 \%)$ and they have 22,000 collection bins distributed locally. Every year, SOEX purchases 90,000 tonnes of clothing from the Red Cross in Germany in addition to 36,000 tonnes from the Salvation Army, Goodwill and Rescue Mission in the United States. In 2012, SOEX total collection amount for used clothing and shoes was 146,000 tonnes (SOEX Group, 2014). The innovative retailing take-back program managed by I:CO has also contributed to a larger collection and customer awareness.

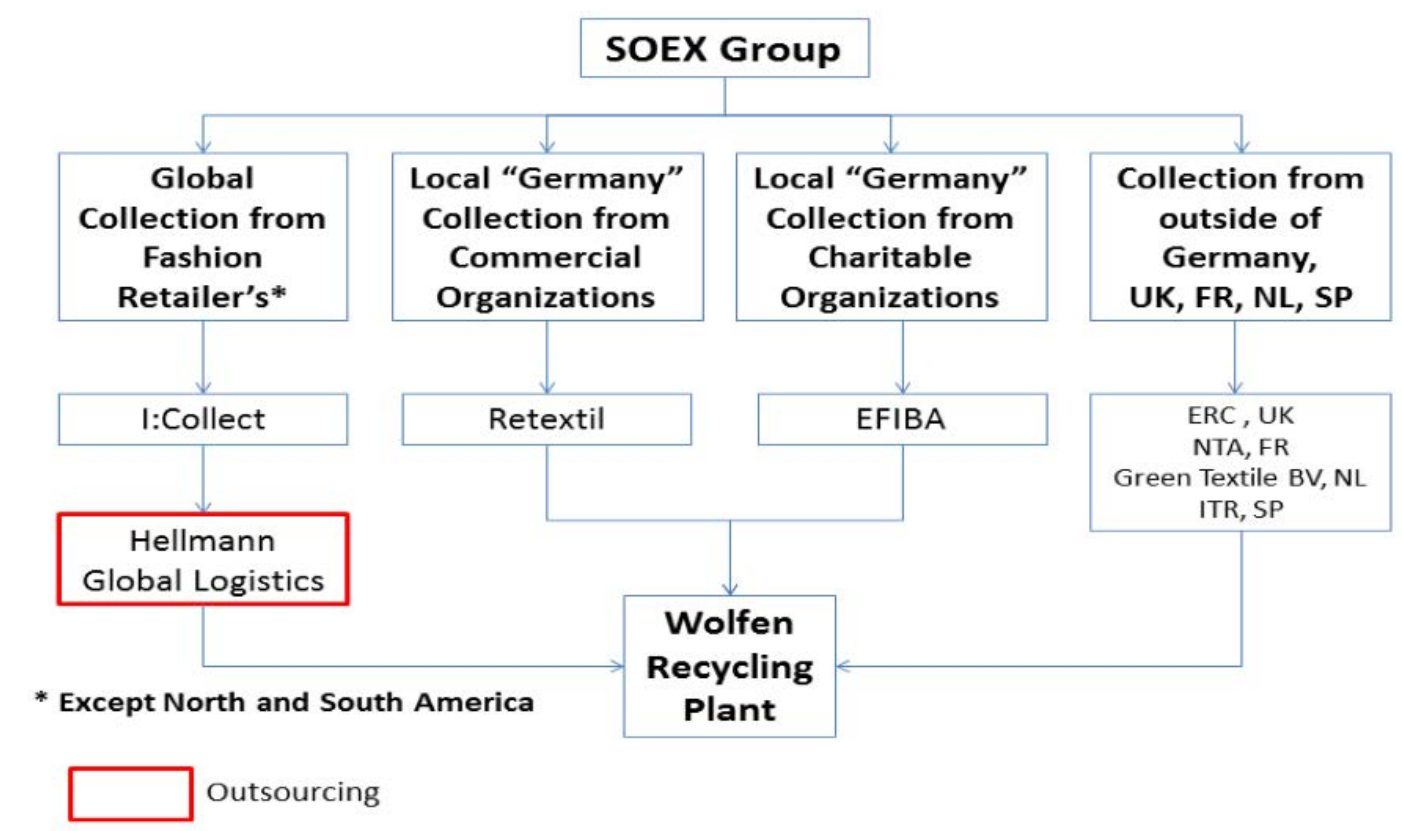

Figure 4-8 SOEX group collection schemes

$\mathrm{I}: \mathrm{CO}$ is a unique system for collecting garments in stores and then processing them for recycling. It is marketing SOEX innovative sorting system and their 


\section{Qualitative Studies}

utilization channels for used products to leading fashion retailers such as the North Face, H\&M and many others, and establishing long-term partnerships with them. All fashion products, including leather clothing and furs, underwear and socks, belts and bags, bed, table and household linen and cushions, are collected in the designated I:CO boxes inside retailers' stores. Customers will obtain a reward shopping voucher depending on the total weight that has been placed ( $10 \%$ or 5 Euros discount per kilo). The total capacity of I:CO box is about

$6 \mathrm{Kg}$. When the box is full, the store seals the shipping box and brings it to the store shipping area to be ready for pick-up. Then, all collected items in Europe will be delivered to SOEX's Wolfen sorting facility for sorting and recycling.

\subsubsection{Sorting}

There are many sorting and recycling businesses founded in Germany for textile recovery. SOEX Group is one of the biggest businesses there. Wolfen plant sorts around $20 \%$ of the used clothing collected in Germany. Wolfen plant, founded in Germany in 1998, is considered one of the largest sorting facilities for used textile and clothing in the world. It has an area of $89,000 \mathrm{~m}^{2}$ where 700 employees are working in 3 shifts to sort 400 tonnes of garments every day. Collected articles are scaled and registered before passing into the sorting processes. The sorting process consists of separation (where shoes, residual waste, and bed feather are separated), presorting (garments are sorted per clothing type, e.g. pants, T-shirt, etc.), and fine sorting according to the quality of 
wearable clothing. Trained staff sort the used items according to 350 different criteria to suit fashion aspects and different client-oriented criteria. It has been reported that $60 \%$ of the collected articles are re-wearable $(10 \%$ of clothing is in good shape and $50 \%$ is not but still re-wearable). $15 \%$ is re-used in textile industry to produce wipers. Around $20 \%$ is re-cycled to be used as filling or insulation materials to different industries. The remaining and unusable materials which account for $5 \%$ will be sent to incinerators. Table 4.8 summarizes the sorting performance of SOEX. (Mzikian, 2013)

\section{Table 4.8 Sorting performance of SOEX Wolfen plant}

Own development based on (Mzikian, 2013)

\begin{tabular}{|l|}
\hline SOEX Sorting Performance \\
\hline Total material recovery rate $>90 \%$ \\
\hline Re-wear rate $>50 \%$ \\
\hline Recycling rate (unraveling or wiping) $>30 \%$ \\
\hline Elimination rate without energy recovery $=5 \%$ \\
\hline
\end{tabular}

\subsubsection{Recycling and Re-distribution}

The recycling system of SOEX is also mechanical which is used to make products that are similar to the one discussed in the French case. Around 15,000 tonnes of used clothing ae being processed and recycled every year in Wolfen plant to create fleece materials that can be used in producing insulating materials and protective sheeting for painting (see Figure 4-9). Unwearable single-color tshirts are converted into wiping cloths in-house. In addition, wearable items that are in good condition would be up-cycled and re-designed to be unique and one of a kind fashionable pieces to be marketed in shops. SOEX owns two second- 


\section{Qualitative Studies}

hand clothing businesses to sell high quality used clothing: Cash4brands and Modemarkt Freestyle $\mathrm{GmbH}$. Cash4brands is an innovative online platform for selling name-brand and designer clothing while Modemarkt Freestyle GmbH has branches in Hamburg, Munich and Berlin offering a large selection of secondhand clothing and trendy vintage fashion from the 60's, 70's and 80's. However, $10 \%$ of the output of sorting and recycling is sold in Germany; $47 \%$ is sold in Africa; 26\% in the Western Europe; $14 \%$ in the Middle East; and 3\% in Asia and America (Figure 4-10). (Mzikian, 2013)

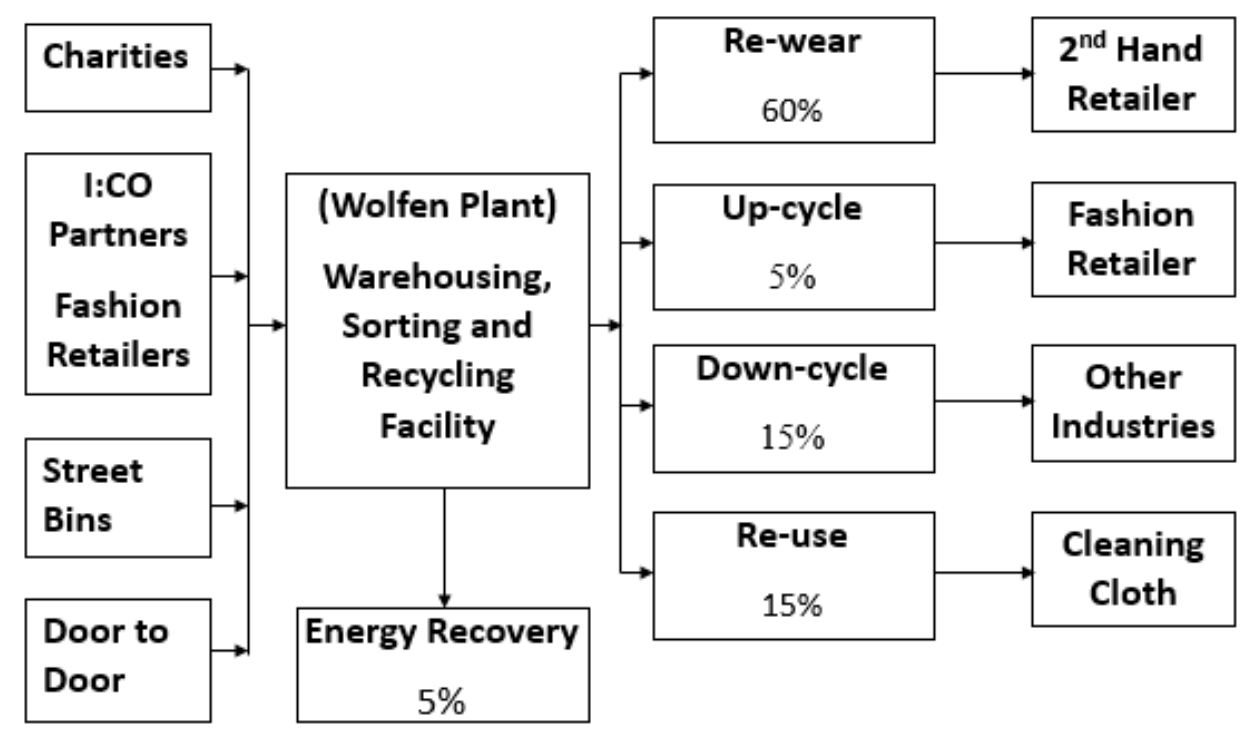

Figure 4-9 SOEX collection and recovery channels for used clothing 


\section{Chapter 4}

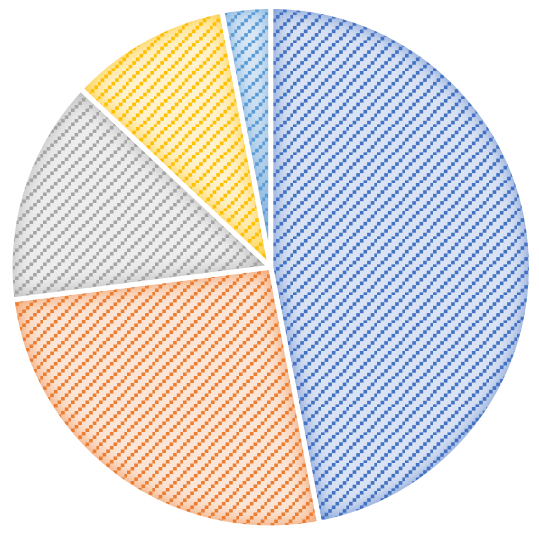

Africa (47\%)

a East Europe (26\%)

\ Middle East (14\%)

\ Germany (10\%)

口 Asia (3\%)

Figure 4-10 Sales of Wolfen plant output

Source: (Mzikian, 2013) 


\section{Chapter 5}

\section{QUANTITATIVE STUDIES}

The qualitative studies, presented in the previous chapter, have allowed us to understand the textile flow after end-of-use and thus enable us to analyze different aspects of the current reverse logistics activities. In this chapter, I present a simple linear programming model to analyze the transportation cost and carbon emissions for the current reverse logistics network in Paris, France. The has been extended to propose a mixed integer linear programming model to help organizations making strategic decisions to select the optimal storage sites, sorting facilities, and recycling plants. 


\section{Chapter 5}

\subsection{Linear Programming Model for Textile Recovery}

\subsubsection{Model Formulation}

\subsubsection{Indices and sets}

i: index for collecting points

p: index for recycling plant

c: index for collected clothing

$q_{i p}$ : Quantity of cloth shipped from collection point i to recycling plant $\mathrm{p}$

$v_{i p}$ : Unit cost of transporting collected cloth from collection points $\mathrm{i}$ to recycling plant $\mathrm{p}$

$q_{c}$ : Total quantity of textiles collected

$Y_{p}$ : total quantity of collected products sorted and treated through recycling plant $\mathrm{p}$ $M A X_{p}$ : upper limit for the annual capacity of recycling plant $\mathrm{p}$ $M I N_{p}$ : lower limit for the annual capacity of recycling plant $\mathrm{p}$

\subsubsection{Objective function}

Minimization of transportation cost:

$$
\sum_{i} \sum_{p} q_{i p} \cdot v_{i p}
$$

Transportation cost includes the cost from collection points to recycling facilities.

\subsubsection{Problem Constraints}

\section{Flow conservation}

a) Total Qty. at collection points = Qty. from collection points to recycling plants.

$q_{c}=\sum_{p} q_{i p}$, for all i

b) Total Qty. at recycling plants = Qty. from collection points to recycling plants 


\section{Quantitative Studies}

$Y_{p}=\sum_{i} q_{i p}$, for all $\mathrm{p}$

Capacity of recycling facilities

$$
\begin{aligned}
& Y_{p} \leq M A X_{p}, \text { for all } \mathrm{p} \\
& Y_{p} \geq M I N_{p}, \text { for all } \mathrm{p}
\end{aligned}
$$

\section{Non-negativity}

\section{$q_{\text {ip }} \geq z e r o$}

The flow conservation constraint guarantees that all textile waste collected from collection bins are sent to one of the recycling facilities. The capacity constraint ensures that the model will consider the capacity of recycling facilities. The non-negativity constraints prohibit negative amount of textile to exist.

\subsubsection{Assumptions}

We assume that all waste must be collected in a single period planning horizon (1 year) and that recycling facilities are already available to handle the collected textile. Landfilling of collected textile happens at the recycling facility, where waste is classified.

In our particular model, we assume the following:

- Recycling plants are already existing.

- Recycling cost is equal across all recycling facilities.

- Storage costs, if exist, are a part of the transportation cost.

- Full-truck load is considered as a transportation mode.

- Recycling plant capacity is unlimited. 


\section{Chapter 5}

- Recycling plants are collecting the maximum amount possible to comply with demand requirements.

\subsubsection{Input data}

\subsubsection{Amount of used textile}

Based on previous study conducted by Bukhari et al. (2017), post-consumer textile is mainly collected by charities and recycling organizations using on-street collection bins/containers. The volume of textile collection bin is about 2 cubic meters (but 80 percent can be utilized) $(1600 \mathrm{~L}=320 \mathrm{~kg})$. In addition, consumers can place their used clothing in drop-off boxes located inside fashion shops such as H\&M and OKAIDI. The capacities of such take-back collection boxes vary across retailers between $500(100 \mathrm{~kg})$ to 1500 liters $(300 \mathrm{~kg})$. Overall, there are more than 40,000 collection points distributed in France. In our analysis, we consider a sample of collection points that are placed in the center of Paris. The location and holder of each collection point can be found in the website (https://www.lafibredutri.fr/je-depose). There are more than 400 textile collection point found in Paris central area using the postal code from 75000 to 75020. We categorize these collection points based on their recycling destinations in Table 5.1. Recently, the textile collected in Paris (see Figure 5-1) is either recycled around Paris or has to travel to specific destination based on its owner (Figure 5-2).

The population in France was about 66.9 million when textile collection reached 210,000 tonnes in 2016. There are 2.24 million habitants live in Paris 


\section{Quantitative Studies}

(3.3\%) so we can estimate the textile collection in Paris alone to be 6700 tonnes.

We consider this collected amount to be normally distributed over the containers, so that each collection point receives 16.4 tonnes of used textile annually.

Table 5.1 Location and holders of used textile collected in Paris

\begin{tabular}{|c|c|c|c|c|c|}
\hline $\begin{array}{c}\text { Textile } \\
\text { Destination }\end{array}$ & $\begin{array}{c}\text { Distance } \\
\text { from Paris } \\
\text { (KM) }\end{array}$ & $\begin{array}{c}\text { Collection } \\
\text { Agent }\end{array}$ & $\begin{array}{c}\text { Textile } \\
\text { Holders }\end{array}$ & $\begin{array}{c}\text { No. of } \\
\text { collection } \\
\text { points }\end{array}$ & $\begin{array}{c}\text { Recycling } \\
\text { Share }\end{array}$ \\
\hline $\begin{array}{c}\text { Paris, } \\
\text { France }\end{array}$ & 1 to 20 & $\begin{array}{c}\text { Local charities } \\
\text { and shops }\end{array}$ & $\begin{array}{c}\text { Various (Le } \\
\text { Relais, ...) }\end{array}$ & 285 & $70 \%$ \\
\hline $\begin{array}{c}\text { Appilly, } \\
\text { France }\end{array}$ & 110 & ECOTEXTILE & FRAMIMEX & 107 & $26 \%$ \\
\hline $\begin{array}{c}\text { Wolfen, } \\
\text { Germany }\end{array}$ & 900 & $\begin{array}{c}\text { IDKIDS, } \\
\text { OKAIDI, } \\
\text { H\&M }\end{array}$ & I:CO & 16 & $4 \%$ \\
\hline
\end{tabular}

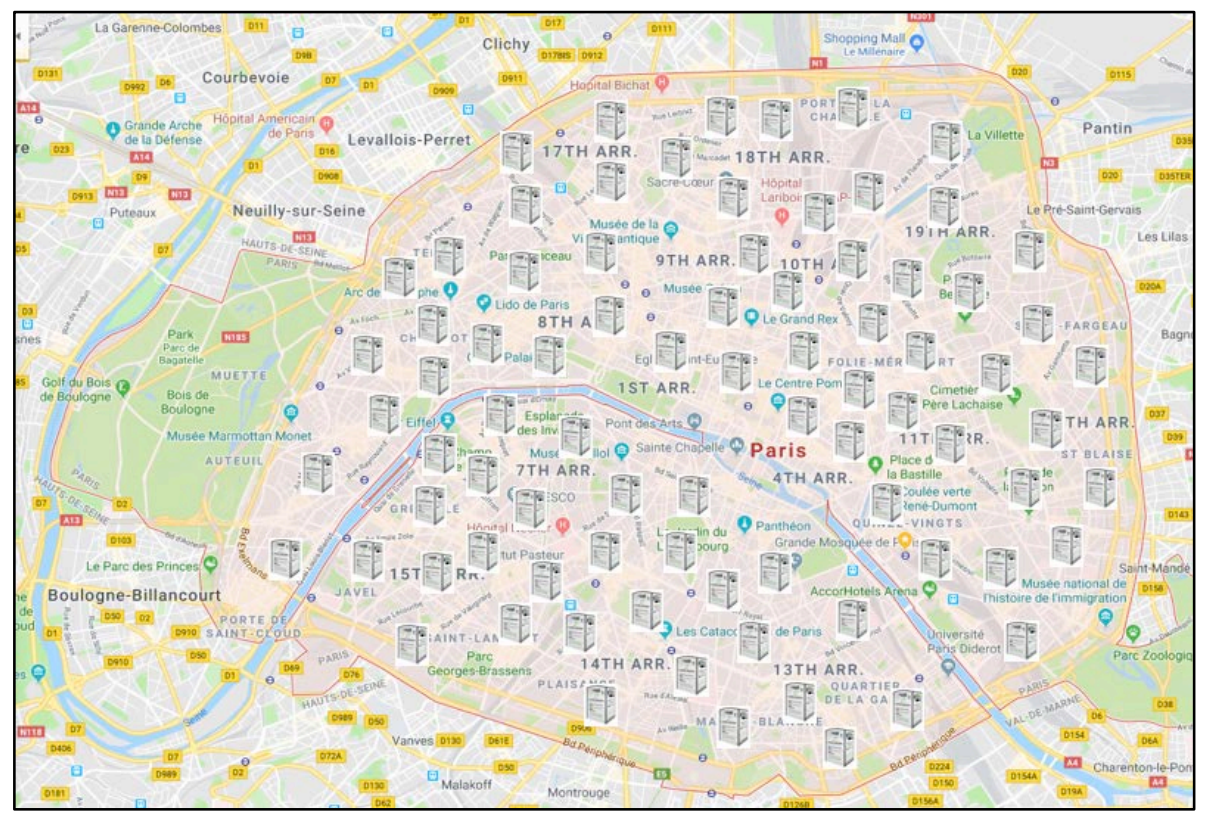

Figure 5-1 Representation for collection points distributed in Paris, France 


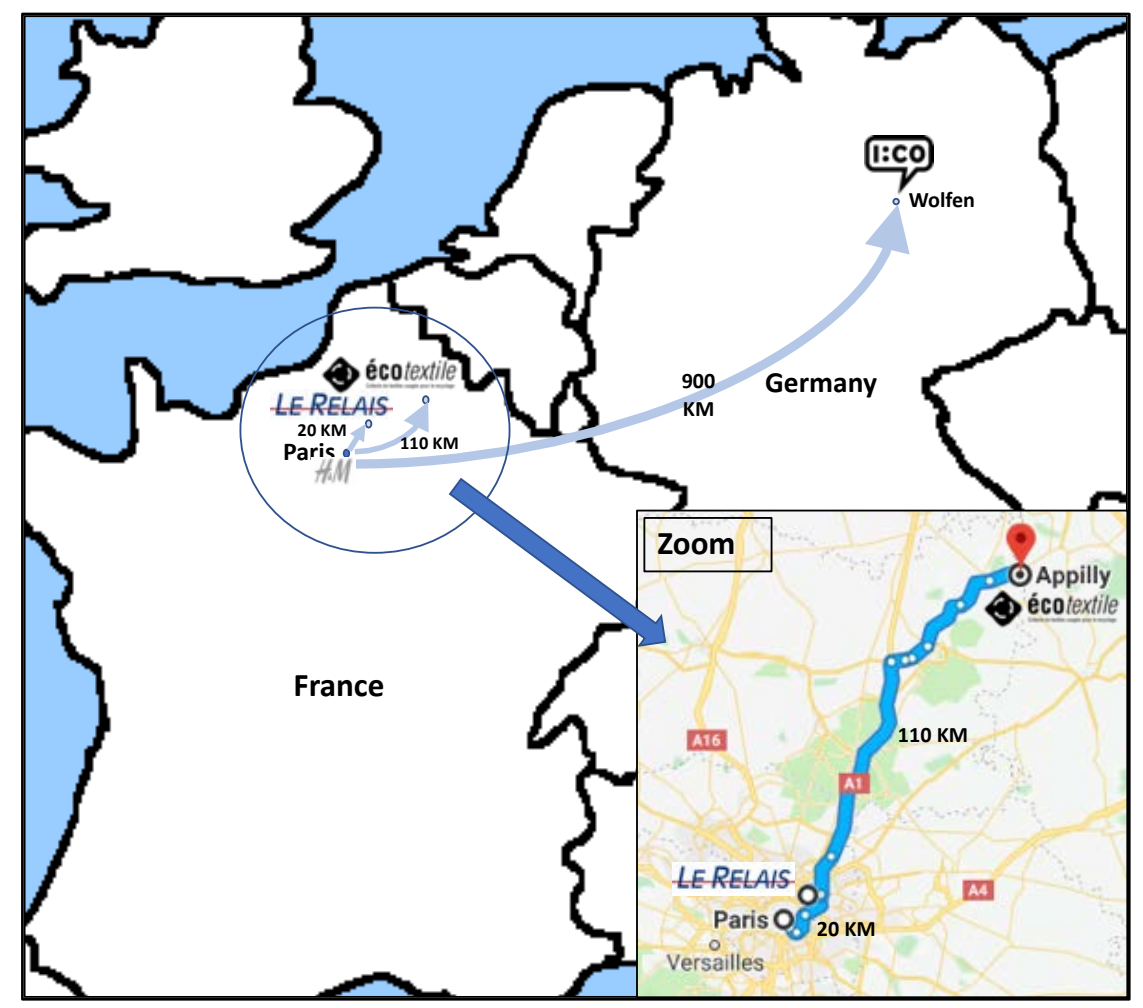

Figure 5-2 Collection channels of used textile from Paris, France

Distances have been determined using google maps by selecting shortest driving routes from center of Paris to the recycling facilities addresses ( $+10 \mathrm{KM}$ added to account for extra costs of inter-city traffic).

\subsubsection{Transportation cost and $\mathrm{CO}_{2}$ emissions}

The transportation cost has been estimated considering full load truck $(2.3 \mathrm{x}$ $2.2 \times 6.1 \mathrm{~m})$ that holds a maximum capacity of 5 tonnes or $30000-$ liter volume. Trucks that travel more distance will cost more, so we can estimate the cost for each truck load as shown in Table 5.2.

We consider a variable cost of $€ 3.5$ per KM-distance and additional of $€ 0.8$ for each tonne loaded. We have multiplied each truck-load channel by the factors 2 , 1 and 0.5 for Paris, Appilly and Wolfen respectively. This is to ensure that our analysis is conservative and accounts for a discount rate for large distance as well 


\section{Quantitative Studies}

as high rate for short travel distance. We also consider potential $\mathrm{CO}_{2}$ emission of 105 gram for each tonne loaded of each KM distance (Time for change, 2017).

Table 5.2 Estimation of transportation cost and emission for different truck-load destinations

\begin{tabular}{|l|c|c|}
\hline Textile Destination & Transportation Cost (\$) & $\mathbf{C O}_{\mathbf{2}}$ Emissions (Kg) \\
\hline Paris & 148 & 10.5 \\
\hline Appilly, France & 389 & 58.75 \\
\hline Wolfen, Germany & 1577 & 472.5 \\
\hline
\end{tabular}

\subsubsection{Results and Discussion}

Using the data given in the previous section, we have developed a base-line scenario for the actual trend with a projection for increasing amount of textile collected by the same textile holders. This can represent wider areas and regions, where more textile is getting collected. We observe a radical increase in the transportation cost and $\mathrm{CO}_{2}$ emissions for the actual case, where there is a $70 \%$ potential reduction for both. Figure 5-3 shows the increase of transportation cost for individual channels as well as aggregated channels which represent the actual (case 1) and the optimized (case 2) projections. Similarly, Figure 5-4 shows the projection of increasing emissions for each case. 


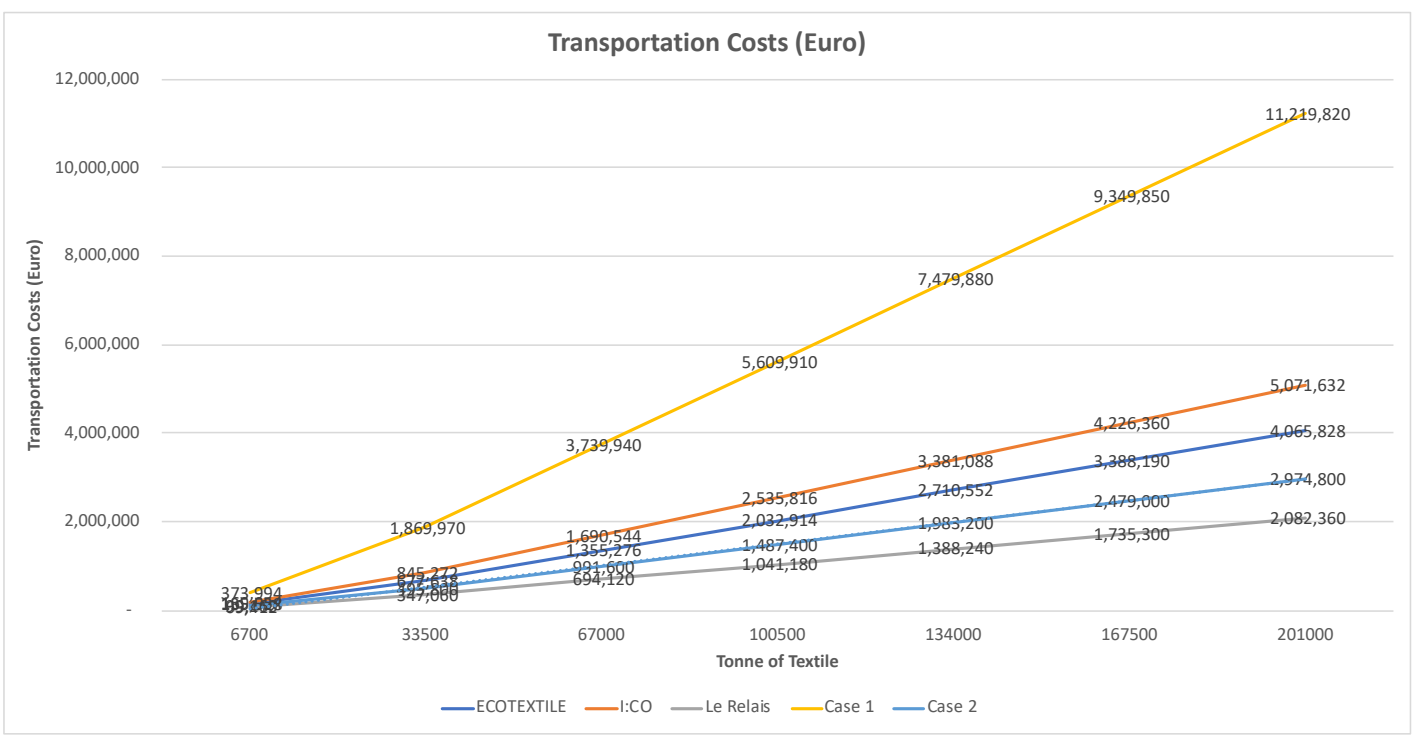

Figure 5-3 Projection of transportation cost for collecting used textile from Paris, France

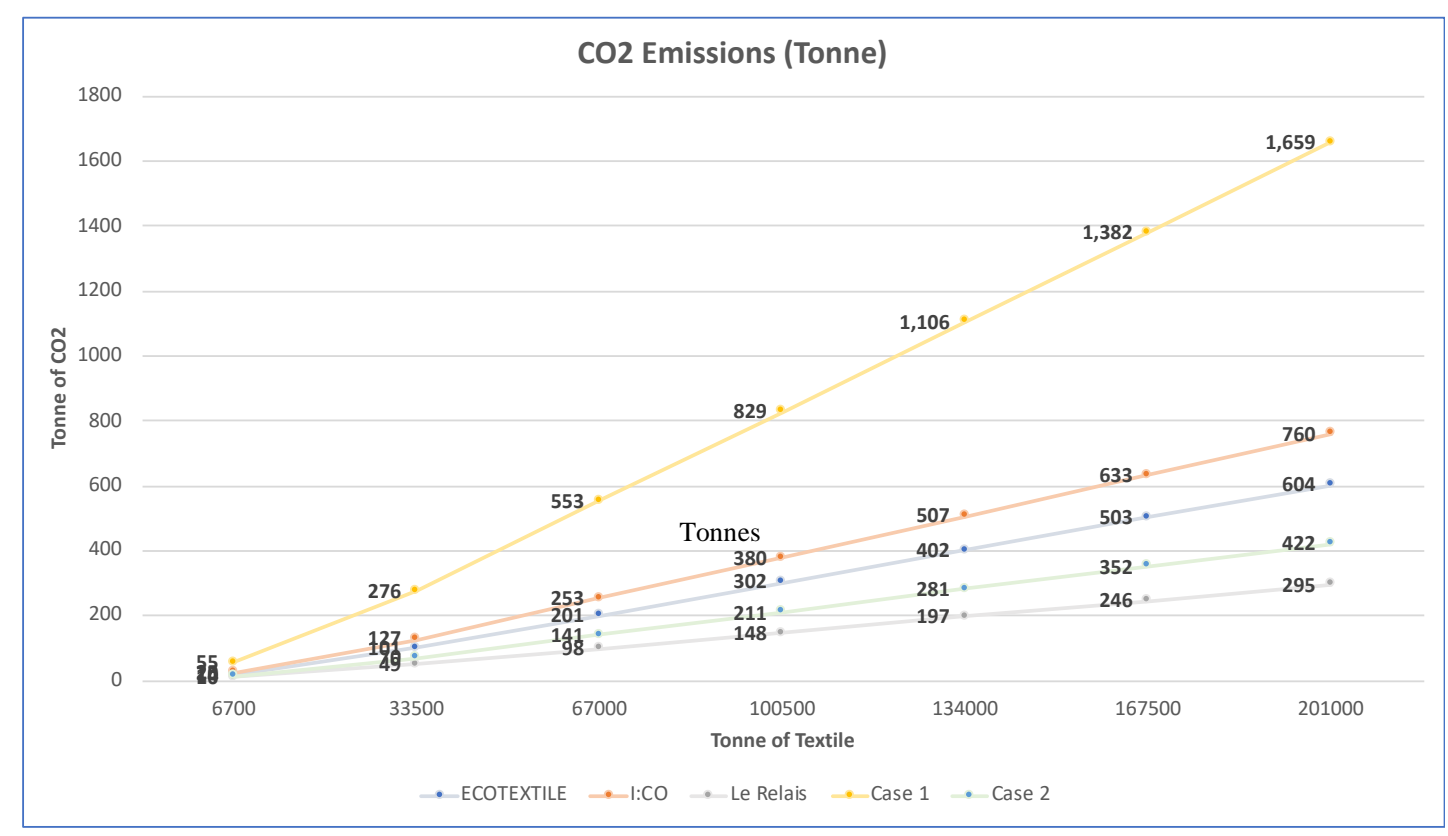

Figure 5-4 Projection of $\mathrm{CO}_{2}$ emission for collecting used textile from Paris, France

Developing a centralized network of collection and recycling would promote a tremendous savings not only in transportation cost but also in $\mathrm{CO}_{2}$ emissions. Despite engines improvement in fuel efficiency for heavy-duty vehicles, the CO2 


\section{Quantitative Studies}

emissions rose $30 \%$ between 1990 and 2007 because of the increase of road freight traffic (EC, 2016). 25\% of the total road transport emissions are produced by lorries, buses and coaches in Europe (EC, 2016). We can observe from the figures above that optimizing the allocation of textile considering the recycling plant distance would reduce the transportation costs from $€ 11$ million to $€ 3$ million and the $\mathrm{CO}_{2}$ emissions from 1600 tonnes to 400 tonnes for transporting 200 thousand tonnes of textile. France has a textile collection target of 300 thousand tonnes that

need to be achieved by 2020 . By then, the transportation cost will exceed $€ 16$ million if linear model was considered and other parameters were equal. By then, optimizing the collection would promote a cost saving of more than $€ 11$ million. 


\section{Chapter 5}

\subsection{Mixed Integer Linear Programming Model for Textile Recovery}

The design of efficient logistics network is a strategic decision that the organizations need to address before introducing new products or add new processes. Different researchers have studied the design of reverse logistics networks in different configurations and industries (Barros et al., 1998; Bloemhof-Ruwaard et al., 1999; Krikke et al., 1999; Fleischmann, 2001; Jayaraman et al., 2003) to minimize the total cost of products collection and recycling. The authors propose mixed integer linear models focusing on different recovery options (e.g., reuse or remanufacturing) and representing multi-stage reverse logistics network. For instance, Barros et al. (1998) proposed a multi-level capacitated warehouse location model applied to the case of sand recycling in the Netherlands to minimize the logistics cost. Krikke et al. (1999) presented a model for photocopy machines to optimize the total operation cost of the reverse logistic network (optimal location and flow of goods). (Spengler et al., 1997) proposed a multi-level warehouse location model for the recycling of industrial by-products in the German steel industry. The objective of the model is to minimize the total cost to transfer products from origination sites through collection sites to the destination facilities and the fixed cost of opening the collection and destination sites. In this paper, we propose a multi-level capacitated storage and recycling facilities for the EoU textile and clothing, accounting for the market demand location. A reverse logistic system requires the coordination of a series of 


\section{Quantitative Studies}

separate activities and operations in order to manage it in an efficient way. Determining the right facilities for storing and recycling post-consumer textile is important. The model proposed is a generic and multi waste model of a threelevel reverse distribution network with local, regional, and central facilities. The main purpose of this model is to decide among an array of different facilities if they will be opened or closed, if they will be sorting or just consolidating, and ultimately the flow of sorted waste in the reverse logistics network while minimizing total cost. We assume that all waste must be collected in a single period planning horizon and that recycling facilities are already available to handle the collected waste. Landfilling of collected waste happens at the sorting facility, where waste is classified, or as a by-product of inappropriate waste received at a recycling facility. This model is formulated as a mixed integer linear program (MILP) and is described in next sections.

\subsubsection{Model Formulation}

We consider (three-level location problem/ 4-tiered network): 1) potential locations of storage sites 2) potential location of recycling facilities, locations of the market we need to meet. We will select storage sites and recycling facilities first then we assign a storage site and recycling facility for each collection point based on the geography of the available markets for recycled materials. The model will allow us to study the economic consequences resulting from decisions 


\section{Chapter 5}

on the location of storage sites and recycling facilities in the context of textile industry.

\subsubsection{Indices and sets}

Indices and sets:

i: index for collecting points

$\mathrm{j}$ : index for storage site

$\mathrm{k}$ : index for recycling plant

l: index for material market

$\mathrm{n}$ : index for output product (2nd hand cloth, wiping cloth,..)

$C_{i}$ : Available supply at Collection point i (tons)

$S_{j}$ : Available quantity at Storage site j (tons)

$R_{k}$ : Available quantity at Recycling plant k (tons)

$M_{l_{n}}$ : Available quantity at of material $\mathrm{n}$ at market $\mathrm{l}$ (tons)

$Q_{k_{n}}:$ Available quantity of material $\mathrm{n}$ at recycling plant k (tons)

$G_{n}$ : fraction of material or product n obtained from recycling

$f_{j}$ : fixed cost for setting a storage site

$f_{k}$ : fixed cost for setting a recycling plant

$v_{i j}$ : Transportation cost from collection point i to storage site $\mathrm{j}$

$v_{j k}$ : Transportation cost from storage site $\mathrm{j}$ to recycling plant $\mathrm{k}$

$v_{i k}$ : Transportation cost from collection points $\mathrm{i}$ to recycling plant $\mathrm{k}$

$v_{k l_{n}}$ : Transportation cost from recycling plant $\mathrm{k}$ to material market $\mathrm{l}$ for material $\mathrm{n}$

$y_{j}: 0 / 1$ variable for selection of storage site

$y_{k}: 0 / 1$ variable for selection of recycling plant

$x_{i j}$ : Quantity of used clothing collected from collection point $\mathrm{i}$ to storage site $\mathrm{j}$

$x_{j k}$ : Quantity of cloth shipped from storage site $\mathrm{j}$ to recycling plant $\mathrm{k}$

$x_{i k}$ : Quantity of cloth shipped from collection point i to recycling plant $\mathrm{k}$

$x_{k l}$ : Quantity of cloth sold by recycling plant $\mathrm{k}$ to the market 1

$x_{k l_{n}}$ : Quantity of product/material $\mathrm{n}$ sold by recycling plant $\mathrm{k}$ to the market $\mathrm{l}$

$M A X_{j}$ : upper limit for the annual capacity of storage site $\mathrm{j}$

$M I N_{j}$ : lower limit for the annual capacity of storage site $\mathrm{j}$

$M A X_{k}$ : upper limit for the annual capacity of recycling plant $\mathrm{k}$

$M I N_{k}$ : lower limit for the annual capacity of recycling plant $\mathrm{k}$

$M A X_{l_{n}}$ : upper limit for the annual demand of the market 1 for product $\mathrm{n}$

$M I N_{l_{n}}$ : lower limit for the annual demand of the market 1 for product $\mathrm{n}$ 


\section{Quantitative Studies}

\subsubsection{Objective function}

Minimization of (fixed costs + variable costs)

$\operatorname{Min} Z=\sum_{j} f_{j} . y_{j}+\sum_{k} f_{k} . y_{k}+\sum_{i} \sum_{j} v_{i j} \cdot x_{i j}+\sum_{j} \sum_{k} v_{j k} . x_{j k}+\sum_{i} \sum_{k} v_{i k} . x_{i k}+\sum_{n} \sum_{k} \sum_{l} v_{k l_{n}} . x_{k l_{n}}$

- Fixed costs $=$ Initial cost/ contract cost of storage/consolidation sites (if exist) + Initial cost/ contract cost of recycling facilities (if exist)

$$
\sum_{s} f_{s} S_{s}+\sum_{p} f_{r} P_{r}
$$

- Variable costs $=$ Sum of transportation cost incurs from transporting textile from: collection points to storage sites, storage sites to recycling facilities, collection points to recycling facilities, and recycling facilities to the end market

$$
\sum_{i} \sum_{s} q_{i s} . v_{i s}+\sum_{s} \sum_{p} q_{s p} . v_{s p}+\sum_{i} \sum_{p} q_{i p} . v_{i p}+\sum_{p} \sum_{t} \sum_{j} q_{p t j} . v_{p t j}
$$

\subsubsection{Problem Constraints}

1- Flow Conservation:

$\sum_{j} x_{i j}+\sum_{k} x_{i k}=C_{i}, \forall i \in C$

$\sum_{i} x_{i j}=S_{j}, \forall j \in S$

$\sum_{k} x_{j k}=S_{j}, \forall j \in S$

$\sum_{i} x_{i k}+\sum_{j} x_{j k}=R_{k}, \forall k \in R$

$\sum_{k} x_{k l_{n}}=M_{l_{n}} \forall l, n \in M$

$\sum_{l_{n}} G_{n} . x_{k l}=Q_{k_{n}}, \forall k \in R$

$\sum_{j} x_{i j}-M . y_{j} \leq 0, \forall j$

$\sum_{k} x_{i k}+\sum_{k} x_{j k}-M . y_{k} \leq 0, \forall k$ 
2- Capacity and Demand Constraints:

$\sum_{i} x_{i j} \leq M A X_{j}, \forall j$

$\sum_{i} x_{i j} \geq M I N_{j}, \forall j$

$\sum_{i} x_{i k}+\sum_{j} x_{j k} \leq M A X_{k}, \forall k$

$\sum_{i} x_{i k}+\sum_{j} x_{j k} \geq M I N_{k}, \forall k$

$\sum_{k} x_{k l_{n}} \leq M A X_{l_{n}}, \forall l, n$

$\sum_{k} x_{k l_{n}} \geq M I N_{l_{n}}, \forall l, n$

Linking/Logical constraints for binary variables

$$
\begin{aligned}
& \sum_{j} q_{i s}-M . S_{s} \leq 0 \\
& \sum_{p} q_{s p}+\sum_{p} q_{i p}-M . P_{r} \leq 0
\end{aligned}
$$

Non-negativity constraints:

All decision variables should be equal to or greater than zero

\section{$q_{i s}, q_{s p}, q_{i p}, q_{p t j} \geq z e r o$}

The flow conservation constraints guarantee that all textile collected from collection zones are sent to a recycling facility and distributed to the corresponding markets. The capacity constraint ensures that the model will take the capacity of the storage sites and recycling facilities into consideration. The demand constraint ensures that the market demand will be satisfied. The linking constraints will help the model to recognize the opened storage sites and recycling facilities that allow the materials to pass through. The non-negativity constraints prohibit negative amount to exist. 


\section{Quantitative Studies}

\subsubsection{Assumptions}

- Recycling cost is equal across all recycling facilities

- Transportation mode is mainly truck transport and we don't consider capacity constraint for that

\subsubsection{Input data}

The model can be used by individual organization as well as collective organization to make various strategic decisions for minimizing the total logistics costs. For small location-allocation problems that involve few collection points, location of each collection point should be known. For large problems having thousands of collection points, we can sort the collection points for different zones and then treat the zones as a collection point. The distance between each collection point and potential storage and recycling sites should be given. Below is the list of data should be given to solve the logistics network design problem.

- Annual weight/qty. of collected clothing at each collection point

- Transportation cost per tonne of textile transported one-km distance between two different level of nodes

- Distance from collection point and initial cost for each potential storage sites

- Distance from collection point and initial cost for each potential recycling plant

- Distance from recycling facility of potential markets for each redistribution channel 


\section{Chapter 5}

- Capacity at each storage site, recycling plant

- Demand at each market

\subsubsection{Solving the model}

Solving the model will help making a decision on issues that help organizing the collection and transportation efficiently as well as answering relative questions such as:

- Should we set up new storage/consolidation sites? where should they be located?

- Should we invest in new facilities? Which facility should be opened?

This dissertation doesn't focus on solving and analyzing such decisions. However, I have developed a mixed integer linear programming model using Python programming and its Pyomo optimization package to provide textile recycling professionals with a tool that can be used to optimize their reverse logistics networks for minimizing their logistics costs. The model can be used by businesses work in various sectors and can be adopted to minimize the freight transport travelling distance and $\mathrm{CO}_{2}$ emissions. A full implementation of the model can be found in appendix B. 


\section{Chapter 6}

\section{ORIGINAL CONTRIBUTION AND FUTURE RESEARCH}

In this chapter, we drive the major contribution and knowledge of the dissertation from the studies presented in the previous chapters. We aim to bridge the gap between the EU circular economy transition and the sustainable recovery of the textile waste.

\subsection{Textile Collection and Recycling Channels in France and Germany}

Textile collection and recycling channels are mostly similar in France and Germany. Several types of collaborations between charities, municipalities and private organizations to carry out textile collection and recycling can be observed. Charities may carry out the textile collection and recycling their selves or hire a private firm to manage the collection and recycling of used textile and clothing. Well-preserved clothing ends up in their second-hand shops to be either donated to needy people or sold to second hand buyers. Excess clothes and those that are unwearable are sold to private organizations that collect and recycle used clothing. Private organizations are also authorized to carry out the collection of used textile and clothing directly from consumers and municipalities. Unlike 


\section{Chapter 6}

German municipalities, French municipality do not place central public containers for citizens to dispose their textile waste. Thus, all textile containers in France belong to charities and private firms. Authorized organizations for textile collection can collaborate with producers and retail shops, such as H\&M and Puma, to place containers for textile collection in their stores. Customers can drop off their clothing in these containers to redeem a discount voucher for subsequent purchases. In Germany, retail stores do not need permission from the Federal Environmental Agency to carry the collection in their stores. In France, retail stores should be registered with Eco TLC to officially collect used clothing. Authorized collection organizations in France and Germany can provide doorto-door collection services to consumers.

Collecting and recycling textile bring economic and social benefits to the textile recycling organizations and charities. Charities might either donate used clothing to people in need; re-sell used clothing in second hand market; recycle and sell recycled products; or trade them with recycling organizations. Recycling organizations sort and recycle $\mathrm{T} \& \mathrm{C}$ to re-sell them in different markets and industries. Based on the French PRO report, $50-60 \%$ of used T\&C is re-worn, 30$40 \%$ is recycled, and $5-10 \%$ is landfilled or incinerated. These numerical figures are somehow similar to the German figures. Figure 6-1 shows the channels of the collection, sorting, recycling, and destinations of the used textile and Clothing. 


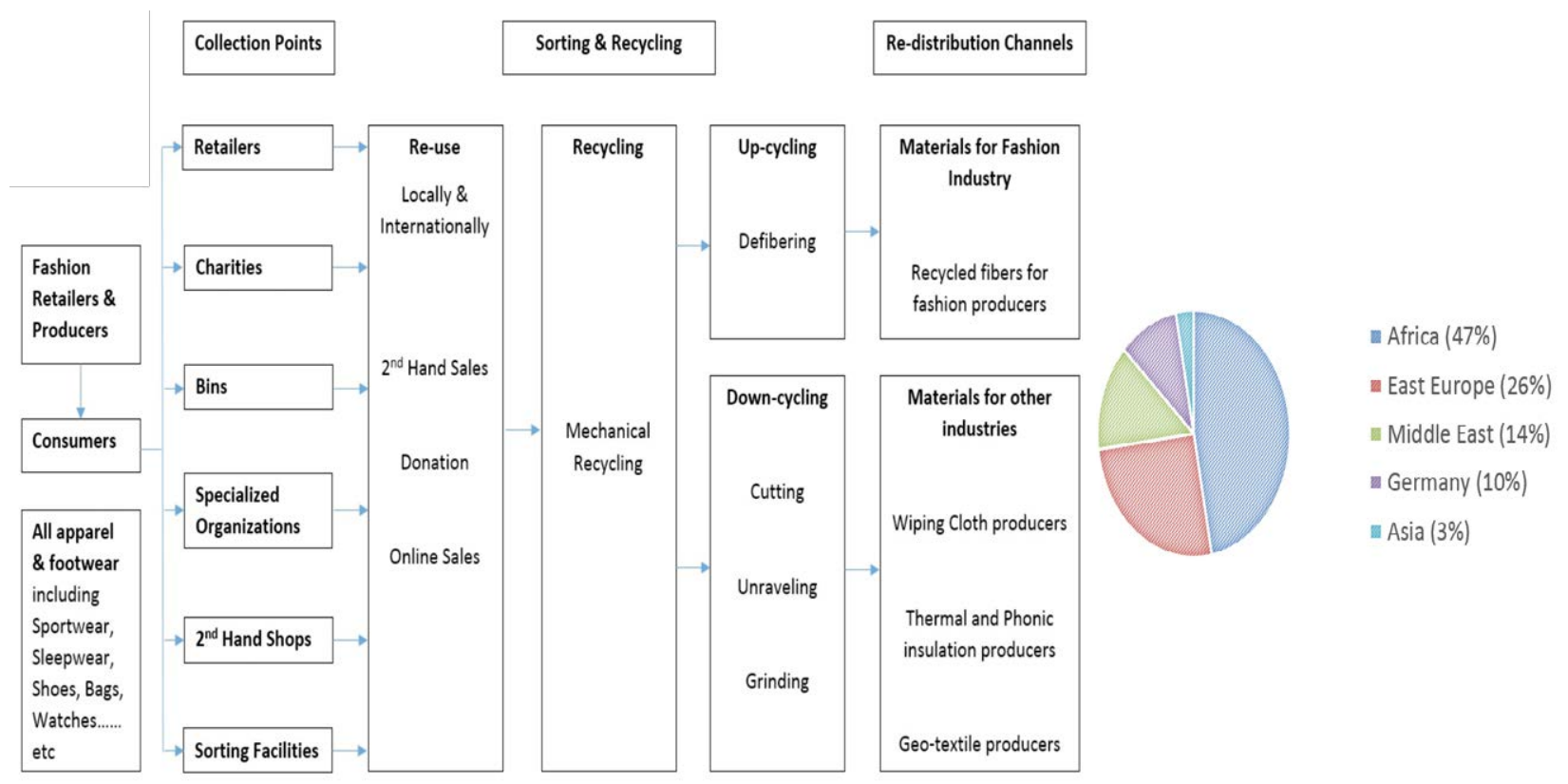

Figure 6-1 Channels of recovering used textile and clothing in France and Germany

\subsection{Current challenges in the current textile and clothing recovery}

\subsubsection{Challenges for used textile reuse}

The market for "re-use", the most preferred option for textiles recovery, has been shrinking in the last few years. Discovering new markets for "re-use" and increasing second-hand clothing demand in Europe are challenging but critical. The quality of new clothing is becoming lower and the export of clothing is becoming more difficult (Recycling expert, personal communication, November 7 , 2017). The "re-use' stream is 10 to $15 \%$ less than what it was three years ago, and African markets are demanding better quality (Recycling expert, personal communication, November 7, 2017). Many Asian and African countries have considered banning the import of EoU materials. For instance, used clothing imports have been outlawed in the Philippines since 2016 (Export.gov, 2016). In 2015, Philippines imported used clothing by $\$ 31.7$ million. China also announced 
that the imports of several wastes will be banned at the end of 2017. The ban will be on 24 types of waste, including EoU PET, PVC, polyethylene and polystyrene, mixed waste paper, used textiles (China's Ministry of Environmental Protection, 2017). Some African countries believe that the import has impacted their domestic production of clothing in the region. For instance, in Kenya, the garment industry that previously employed 500,000 persons has only 20,000 workers presently. Thus, countries in the East African Community (EAC) are considering banning the import of used clothing by 2019 (Mayer, 2016; Omondi, 2016; BBC News, 2016).

The African countries have been a potential for the "re-use" market for many years. Our data shows that more than $40 \%$ of the post-consumer textiles collected in France was exported to African countries in 2015. According to Oxfam, more than $70 \%$ of the clothing donated globally has been sent to Africa (Kubania, 2015). Cameroon and some African countries form the East Africa Community are the largest importers of second-hand clothing. In 2015, the EAC imported secondhand clothing that was worth more than $\$ 150$ million. (BBC News, 2016)

\subsubsection{Challenges for textile sorting and recycling}

Sorting and recycling of textiles suffer from system cost and inefficiency. The current markets for recyclable textiles and clothing are limited. Also, sorting of textiles is very expensive, and it is time and labor intensive (Sherburne, 2009). The use of different fiber blends has made clothing difficult to sort and recycle 


\section{Original Contribution and Future Research}

(Hawley, 2009). Development of automatic sorting technologies that are economically feasible for used textiles and clothing is still under development. On the other hand, advanced recycling technology is required to replace or complement the inefficient mechanical recycling. The mechanical system cannot close the materials loop and it diminishes the fiber length and strength (George et al., 2006). Thus, recyclable textiles are mainly down-cycled to produce wiping clothing or insulation products that can be used in construction and auto industries. Automation of sorting and discovering new technologies for textiles recycling, e.g. chemical recycling, have been given more attention recently and developed systems are expected to shine in the near future.

\subsection{The benefits of the EPR policy for textiles and clothing}

The EPR policy for post-consumer textiles helps the textiles recycling industry to overcome future challenges and create jobs for socially excluded workers. Sorting of textiles has provided 1,400 full-time jobs in France as of 2017, among which $49 \%$ has been reserved for workers facing employment difficulty (Eco TLC 2016a). The PRO is financially support the inclusion of excluded workers. The EMMAÜS community, the biggest not-for-profit community in France, takes a large share of sorting and recycling of clothing and aims to promote the inclusion of excluded workers into the labor force. The community believes that the practices of textile sorting and recycling are opportunities to hire large numbers of a low-skilled workforce because they are labor intensive (Le Relais, 2017). 


\section{Chapter 6}

Sorting and recycling organizations are not financially stable because the quality of collection and the demand for used clothing are not always the same and the price of used clothing is fluctuating. Only 30 to $40 \%$ of the collected materials can cover the recycling cost (recycling expert, personal interview, November 7, 2017).

The tariff contribution paid by fashion retailers and producers is relatively small and valuable for establishing the infrastructure for used textiles collection and recycling. In 2016, fashion retailers introduced 2.5 billion pieces to the French market, including 93,000 pieces of eco-modulated clothing. The share of clothing, linen, and footwear were $82.3 \%, 6.9 \%$ and $10.8 \%$, respectively. According to that, by applying the tariff schedule, the PRO collected $€ 17.2$ million from the

members (an average of $€ 0.0067$ per piece and $€ 28.7$ per tonne) in 2016. This contribution was used to cover the following 2015 expenses: $€ 477$ thousand spent in projects finance, $€ 2.1$ million subsidized local communities for consumerawareness campaigns, $€ 12.8$ million in subsidies paid to charities and private organizations for sorting the collected textiles and clothing, and little budget spent in taxes, staff, offices, and outsourced services. (Eco TLC, 2016a).

The collection and recovery rates of post-consumer textiles have been increasing since 2006. We observe an average annual increase of post-consumer textiles collection of about 13\% since 2006 in France. The amount collected now is three times as much as what was collected 10 years ago. In 2006, 65,000 tonnes were collected while around 210,000 tonnes were collected in 2016. This 


\section{Original Contribution and Future Research}

increasing trend may indicate that the PRO has improved the issues of consumerawareness, numbers and accessibility of on-street collections bins, and the transparency of material and financial flows. The number of textiles containers in 2016 (41,793 containers owned by around 375 entities) was more than twice of what it was in 2011 (15,621 containers owned by around 150 entities). There is a national target to improve the citizens' accessibility to the textiles bins by placing a minimum of one collection bin for every 1500 inhabitants by 2020. (Eco TLC, 2016a)

The EPR policy increases the financial supports for raising the public sustainability-awareness and participation. In 2015, the PRO subsidized €2.1 million to engage 760 local communities to maintain public communication campaigns (Eco TLC, 2016a). It has also established a website and mobile application to allow the citizens to find the closest textiles containers to drop-off their used clothing. The online platform also provides information regarding the social and environmental benefits of the textiles recycling.

Recent studies of textiles recycling show that re-use and re-cycling are more beneficial for the environment than landfill and incineration. Zamani et al. (2016) have compared the potential of GHG emissions and energy savings of the textiles incineration with different recycling techniques using life cycle assessment. He has found that the textiles recycling has a much higher potential of GHG emissions and energy savings. In addition, According to Dutch aWEARness's 
calculations, textiles recycling cuts raw materials demand by $61 \%$ and can promote energy, carbon dioxide and water savings of $64 \%, 73 \%$ and $95 \%$ respectively (EC Eco-innovation, 2017). It cuts raw materials demand by $61 \%$ and, because it is fully recyclable, waste is eliminated entirely. Innovation and creativity are keys for promoting circular economy. We also observe potential transportation cost and carbon emission savings when adopting assigning the collection activities to recycling organizations based on the distance between them (see Chapter 5). Developing a centralized network of collection and recycling would promote a tremendous savings not only in transportation cost but also in $\mathrm{CO}_{2}$ emissions. It is estimated that the transportation cost could be cut from $\$ 11$ million to $\$ 3$ million, while the $\mathrm{CO}_{2}$ emissions from 1600 tonnes to 400 tonnes for transporting 200 thousand tonnes of textile. Since the French's textile collection target is to collect 300 thousand tonnes by 2020, the transportation cost will exceed \$16 million if linear model was considered and other parameters were equal. By then, optimizing the collection would promote a cost saving of more than $\$ 11$ million. Future development of textile programs should consider sustainable collection practices to promote productive, cost-effective and ecofriendly collection strategy.

The French PRO dedicates annual budget of $€ 500,000$ to foster innovative projects (Dubois et al., 2016). Many projects have been financially supported to improve the current sorting and recycling activities. Every year, the French PRO 


\section{Original Contribution and Future Research}

calls for new projects to give opportunities for researchers and institutions to participate and share their innovative ideas and turn them to reality. Approved proposals and projects get funded, up to $50 \%$ of the total cost, and communicated in a document called "Roads to innovation" (Eco TLC, 2016c). As of 2017, 28 projects have been launched that can be categorized into four project areas: 2 ecodesign projects, 6 closed-loop projects, 14 open-loop projects, and 6 projects in used textiles sorting and processes techniques (Eco TLC, 2017). The aim of the current eco-design projects is to develop a new procedure for shoe design and manufacturing to permit easy separation of all components at the post-consumer stage. The closed-loop projects aim to create yarn from used materials such as jeans, socks, polyester, and shoes. The open-loop projects aim to facilitate downcycling used textiles for decorative and industrial use. Finally, the sorting and processes projects seek new methods for textiles sorting and separating of hard components.

The PRO activities to maintain sustainable improvements in the textiles sector are great, but there are still a room for improvement. Despite a 50\% discount on the tariff that has been offered for these items, the discount remains too low to cover the administrative costs linked to the declaration per unit and the certification of the origin of the recycled material used (Eco TLC 2016a). Thus, fashion retailers find it infeasible to report their clothing made out of postconsumer textiles. In addition, they find it easier and more feasible to report and 
use pre-consumer materials obtained from textiles production waste (Eco TLC, 2016a). We observe that the PRO does not give producers incentives such as ecomodule tariff when they ecologically design and source other materials. However, this might be very complex and requires another system to monitor such practices.

\subsection{Circular economy: scope and limitations}

The circular economy should have a clear scope to enable practitioners and researchers to innovate and support it in the right direction. From the EU Circular Economy paradigm, we observe that the scope of the circular economy is simply to promote reuse and recycling for produced goods and packages. This can be clearly observed from the specific targets reported in the proposed Circular Economy Package. By reuse and recycling, Europe intends to reduce the need for landfill and sustain social, economic and environmental growth. For instance, the social growth is attained by offering new employment opportunities for collection, sorting and recycling of textile. The economic growth is attained by collecting the used textile to turn it to get economic return. The environmental protection is attained by seeking Lansink's Ladder of waste hierarchy. Hence, this would reduce the environmental impact of waste landfilling and incineration.

The circular economy doesn't assure sustainable production and consumption as mentioned by the European Commission. Sustainable production and 


\section{Original Contribution and Future Research}

consumption should focus on all production and consumption stages that are shown in Figure 6-2. This requires global perception and more rigorous framework. The circular economy is still seen as a national or regional goal that doesn't assure sustainable production outside of the economy and doesn't require from textile producers to maintain specific sustainable production and consumption targets. In the circular economy, the main goal is to maximize reuse of material, without having clear economic, social, and environmental goals attained from reuse. This can be observed from the set of targets given in the CE package. One of the limitations we observe in the package is that specific collection and recycling targets for textile and other end-of-use materials do not even exist. This brought us to question whether targets are set according to the potential economic or environmental benefits. The EU Circular Economy Package entails four legislative proposals on waste: 1) amending Directive 2008/98/EC on waste, 2) amending Directive 1999/31/EC on the landfill of waste, 3) amending Directive 94/62/EC on packaging and packaging waste, and 4) amending Directives 2000/53/EC on end-of-life vehicles, 2006/66/EC on batteries and accumulators and waste batteries and accumulators, and 2012/19/EU on waste electrical and electronic equipment. However, amending of aforementioned directives implies that all waste and landfilling targets will be reported in the Circular Economy Package ${ }^{1}$. There are no specific targets textile

\footnotetext{
${ }^{1}$ http://www.europarl.europa.eu/EPRS/EPRS-Briefing-573936-Circular-economy-package-FINAL.pdf
} 
or other materials except packaging, thus specific targets for all industries should be introduced for reuse and recycling (see Table 6.1)

\section{Table 6.1 Proposed waste management targets}

Source: (EC, 2017)

\begin{tabular}{|l|c|c|}
\hline \multirow{2}{*}{ Target } & \multicolumn{2}{|c|}{ Year } \\
\cline { 2 - 3 } & $\mathbf{2 0 2 5}$ & $\mathbf{2 0 3 0}$ \\
\hline Share of municipal waste prepared for reuse and recycling & $60 \%$ & $65 \%$ \\
\hline Share of municipal waste landfilled & - & $10 \%$ \\
\hline $\begin{array}{l}\text { Share of all packaging waste prepared for reuse and } \\
\text { recycling }\end{array}$ & $65 \%$ & $75 \%$ \\
\hline $\begin{array}{l}\text { Share of plastic packaging waste prepared for reuse and } \\
\text { recycling }\end{array}$ & $55 \%$ & - \\
\hline $\begin{array}{l}\text { Share of wood packaging waste prepared for reuse and } \\
\text { recycling }\end{array}$ & $60 \%$ & $75 \%$ \\
\hline $\begin{array}{l}\text { Share of ferrous metal packaging waste prepared for reuse } \\
\text { and recycling }\end{array}$ & $75 \%$ & $85 \%$ \\
\hline $\begin{array}{l}\text { Share of aluminum packaging waste prepared for reuse and } \\
\text { recycling }\end{array}$ & $75 \%$ & $85 \%$ \\
\hline $\begin{array}{l}\text { Share of glass packaging waste prepared for reuse and } \\
\text { recycling }\end{array}$ & $75 \%$ & $85 \%$ \\
\hline $\begin{array}{l}\text { Share of paper and cardboard packaging waste prepared for } \\
\text { reuse and recycling }\end{array}$ & $75 \%$ & $85 \%$ \\
\hline
\end{tabular}

Even if textile recycling targets exist, we might see improvement in the disposal and treatment stages only, which has very limited scope when looking at the sustainable production and consumption stages. We believe that environmental and social dimensions are still secondary comparing to the economic dimension. This can be shown by observing the market figures of the recycled textile.

Recycled textile would have been re-used locally to reduce importing and producing new products instead of shipping half of it to African communities, 


\section{Original Contribution and Future Research}

where it hinders their textile industry development. Global perspective, targets, and policies are required to ensure sustainability locally and globally. We believe that the optimal circular economy, in the current scope, is the economy in which materials are reused and recycled to limit importing and production of similar materials and products. Figure 6-3 is a global model of material flows from resource inputs to material outputs. An indicator for circular economy transition, reduction of resource input in relation to the waste output should be observed. Most of the recycled textile collected in Europe, including France and Germany, are exported to developing countries, which indicate that collected resources do not replace the imported resources. In order to the economy to become circular, at least "re-use" apparel should be hold in the economy without imposing unnecessary emissions on transportation neither to impact the economy of developing countries that are willing to grow.

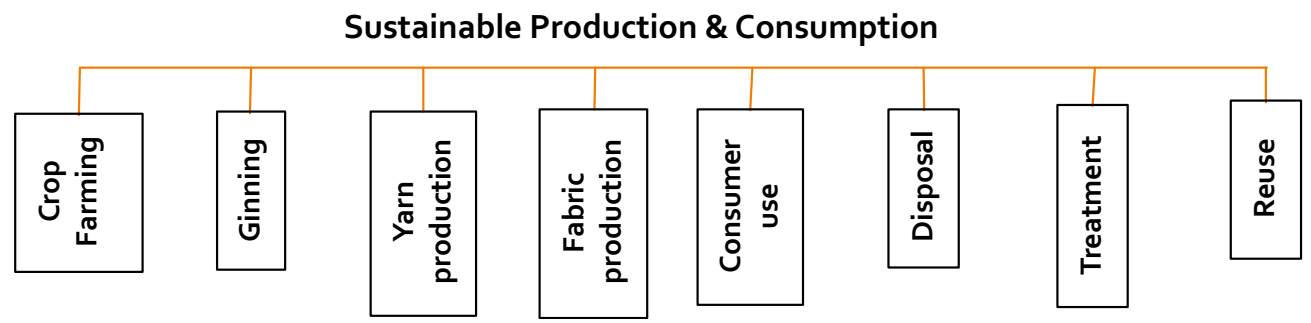

Figure 6-2 Potential stages for promoting sustainable production and consumption of cotton clothing 


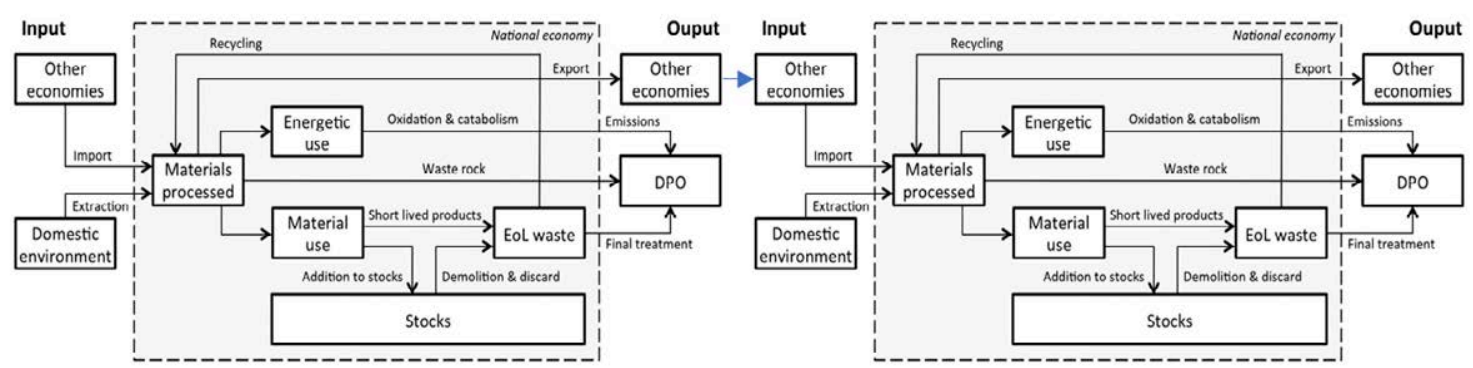

Figure 6-3 Material flows between two economies from resource inputs and imports to outputs of material wastes and exports

Own development based on (Haas et al., 2015).

EoL waste $=$ end-of-life waste; DPO $=$ domestic processed output .

\subsection{Circular Economy: towards a sustainable material recovery}

\subsubsection{Promoting traceability and effective data management}

Traceability of materials and products is at the heart of the circular economy that we need to maintain. Since promoting a circular economy is a national target, developing a non-for-profit national organization to monitor the national flow of products and materials seems to be a vital solution for maintaining traceability. Monitoring the flow of products can provide three benefits: a) help to engage and motivate producers and recyclers for improving their products and processes; $b$ ) help to raise consumer awareness by publishing certain figures and sustainable practices; c) assure accurate data for measuring the circularity of the sector. Eco TLC, the French PRO for textile industry, has developed an information system that allows and encourages all producers and recyclers in the textile sector to communicate and provide certain data relative to their practices. We were able to obtain critical and detailed data for the textile sector in France easily because of the focus and annual publications made by the French PRO. In Germany on 


\section{Original Contribution and Future Research}

the other hand, data is difficult to find, and it is not regularly and officially published. Without finding the consumers report published by Fachverband Textilrecycling (2014), tracing the textile recovery in Germany would not be possible. Data is an important element for measuring the circular economy and great attention should be paid by government's bodies to obtain and publish accurate data. While assessing circularity in Europe, Haas et al. (2015) estimated the recycling rates and mentioned that the data entails considerable uncertainty. Therefore, specific data should be identified and monitored for each sector, where circular economy is adopted.

\subsubsection{Setting up the circular economy for material reuse and recycling}

The circular economy should take advantage of the resources used and "reused" in the same economy which lead to substitute part of the import amount by that, so to increase the resource efficiency in the economy. This cannot be happened except if consumers accepted to wear second-hand clothing or if potential markets for "reuse" exist. Thus, the role of PRO to engage all stakeholders and each has to meet certain goals is critical because the PRO might evolve nationally to cooperate and share its experience, standards, and criteria with other PROs in other economies so that we can reach social and environmental sustainability and global integrity (See Figure 6-4). Used clothing for example, cannot be offered locally unless it has certain values for consumers. Thus, communicating the value for "re-use" to consumers and identifying new 
local markets are crucial. Increasing the demand for recycled textile would ensure sustainable improvement in the used textile market. Raising consumerawareness, may contribute to more demand for recycled goods regardless of how much economic surplus is gained.

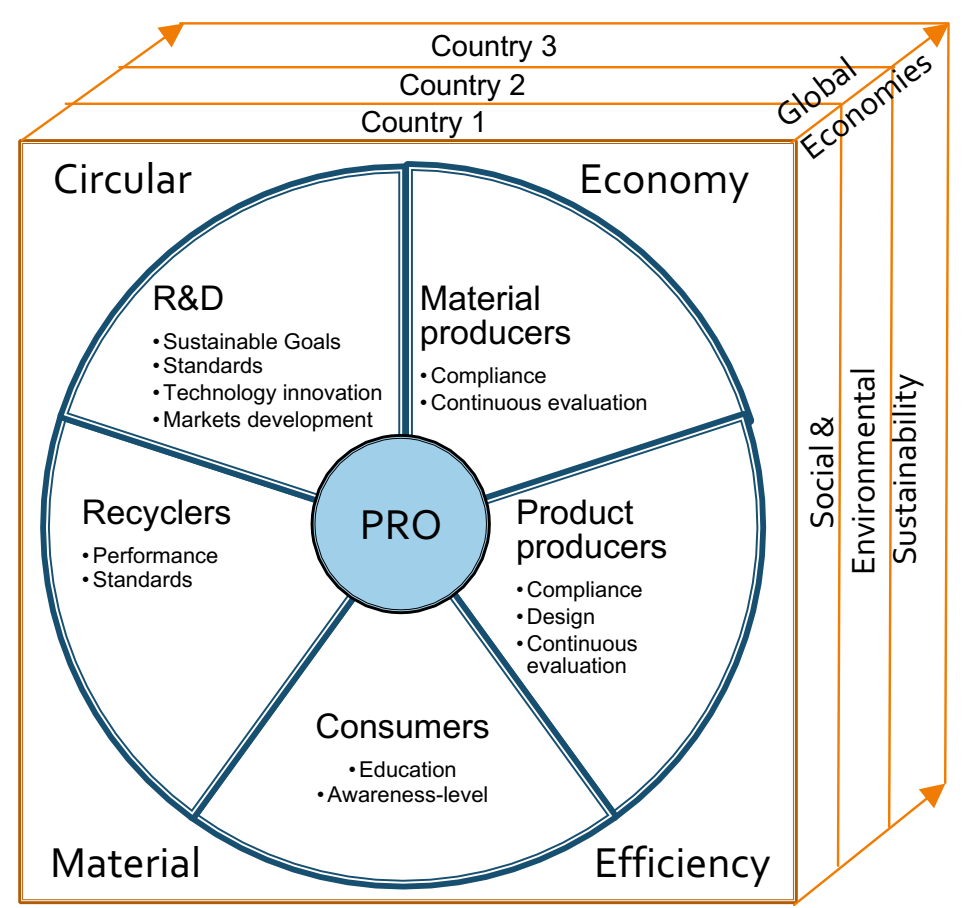

Figure 6-4 Circular economy vault for securing circular industry globally

The PRO has different roles for managing textile waste complying with the European waste hierarchy. First, it motivates consumers and industries to separate and dispose textile waste properly by raising consumer awareness and improving non-waste disposal channels. Second, it manages the textile recovery in a cost-effective manner to cover the collection and recycling expenses. Third, it assists textile producers and recyclers to maintain eco-design and improve sorting and recycling technologies. Forth, it identifies and develops new markets 


\section{Original Contribution and Future Research}

for the sorted and recycled materials. Finally, it integrates the main actors, and which allows it to develop efficient reverse logistics network to minimize the transportation cost and GHG emissions, if it is possible legally. The PRO roles can be shown according to the waste hierarchy level in Figure 6-5.

\begin{tabular}{|c|c|c|}
\hline $\begin{array}{l}\text { - } \quad \text { Raising consumer awareness } \\
\text { - } \quad \text { Improving the non-waste disposal channels } \\
\text { - Developing new non-waste streams }\end{array}$ & $\begin{array}{l}\text { Waste prevention } \\
\text { (Re-use) }\end{array}$ & Non-waste \\
\hline $\begin{array}{l}\text { To help textile collectors by: } \\
\text { - } \quad \text { Reducing the collection points and } \\
\text { increasing the collection volume } \\
\text { To help textile recyclers by: } \\
\text { - Improving sorting technique and criteria } \\
\text { - Improving recycling technology } \\
\text { - Creating new products and market channels } \\
\text { - } \quad \text { Focusing on local and European markets }\end{array}$ & $\begin{array}{l}\text { Preparation for } \\
\text { Re-use } \\
\text { Recycling }\end{array}$ & $\begin{array}{l}\text { Waste } \\
\text { Material } \\
\text { Recovery } \\
\text { System }\end{array}$ \\
\hline $\begin{array}{l}\text { To help government to achieve National Goals: } \\
\text { - Improving the reverse logistics network to minimize } \\
\text { the transportation cost and GHG emissions } \\
\text { - Improving the calorific value of textile waste to } \\
\text { generate higher energy } \\
\text { - Funding innovative sustainable projects for textile } \\
\text { industry }\end{array}$ & $\begin{array}{l}\text { Energy } \\
\text { recovery } \\
\text { Dispose }\end{array}$ & \\
\hline
\end{tabular}

Figure 6-5 The roles of the PRO for recovering textile and clothing

\subsubsection{Identifying important measures and indicators}

We believe that the circular economy should be guided by a set of measurable indicators and practices to trace and measure national transitions. Collection and recycling rates are not valid measures for circular economy, rather they represent how much focus was giving to such practices. More measures should be considered to evaluate the sustainable improvement made by material and product producers, recyclers, consumers purchasing and consumption behavior. 


\section{Chapter 6}

Table 6.2 shows some of the data that helps in reaching valuable measures. France and Germany show different legal framework as well as different collection and recycling rates. Collection and recycling rates do not indicate circular transition. Although high collection and recycling rates are found in Germany, we can't judge wisely whether its framework is what makes it better or whether there are other factors that we need to examine. To make a wise comparison between both cases, we need to have other measures such as: collection rate, capacity and intensity; consumer's spending, purchasing amount, recycling's rates, capacity, and efficiency (shown in Table 6.3).

We propose to give specific ratio (from -1 to 1 ) to each textile recycling channel. The value will represent a product present value in the economy. For instance, we give a ratio of one for "re-use" of used textile nationally, since the product will replace a new product in the economy. This ratio is reduced when the product loses its original value, for instance, we can say: 0.5 for disassembly and upcycle, 0.3 for making rags, 0.15 for producing insulations and used clothing export, 0.05 for energy recovery, -1 for landfilling or incinerators without energy recovery. 
Original Contribution and Future Research

Table 6.2 Data required for measuring the circular performance

\begin{tabular}{|c|c|}
\hline From & Required data \\
\hline Material producers & Kind of crops, harvest area, yield and production data \\
\hline \multirow{3}{*}{$\begin{array}{l}\text { Product producers } \\
\text { and retailers }\end{array}$} & Wight and number of products introduced in the market \\
\hline & Weight and number of products imported \\
\hline & Weight and number of products exported \\
\hline \multirow{4}{*}{ Consumers } & Weight and number of purchased new products \\
\hline & Weight and number of purchased recycled products \\
\hline & Weight and number of clothing disposed in refuse bins \\
\hline & Consumers expenditures on clothing \\
\hline \multirow{3}{*}{$\begin{array}{c}\text { Collection } \\
\text { (including charities } \\
\text { and shops that } \\
\text { collect used textile) }\end{array}$} & Weight and number of clothing collected \\
\hline & Number of collection points per area/ zone \\
\hline & Number of firms practicing collection \\
\hline \multirow{13}{*}{$\begin{array}{l}\text { Recycling } \\
\text { (including charities } \\
\text { if applicable) }\end{array}$} & Weight and number of clothing recycled locally \\
\hline & Weight and number of clothing recycled abroad \\
\hline & Number and capacity of recycling facilities \\
\hline & $\begin{array}{l}\text { Weight and number of clothing sorted as "reuse- } \\
\text { quality1" }\end{array}$ \\
\hline & Weight and number of "reuse-quality1" marketed locally \\
\hline & $\begin{array}{l}\text { Weight and number of clothing sorted as "reuse- } \\
\text { quality2" }\end{array}$ \\
\hline & Weight and number of "reuse-quality2" marketed locally \\
\hline & $\begin{array}{l}\text { Weight and number of clothing sorted as "recycle, } \\
\text { product1" }\end{array}$ \\
\hline & $\begin{array}{l}\text { Weight and number of "recycle, product1" marketed } \\
\text { locally }\end{array}$ \\
\hline & $\begin{array}{l}\text { Weight and number of clothing sorted as "recycle, } \\
\text { product2" }\end{array}$ \\
\hline & $\begin{array}{l}\text { Weight and number of "recycle, product2" marketed } \\
\text { locally }\end{array}$ \\
\hline & $\begin{array}{l}\text { Weight and number of clothing sorted as "energy } \\
\text { recovery" }\end{array}$ \\
\hline & $\begin{array}{l}\text { Weight and number of clothing sorted as } \\
\text { "Landfill/incineration" }\end{array}$ \\
\hline \multirow{3}{*}{ R\&D } & $\begin{array}{l}\text { The value of sorted products ( } 0 \text { to } 1 \text { ) comparing to its } \\
\text { original value (1) }\end{array}$ \\
\hline & Materials used for energy recovery has a value of zero \\
\hline & $\begin{array}{l}\text { Materials go to landfilling and incineration has a value } \\
\text { of }-1\end{array}$ \\
\hline
\end{tabular}


Table 6.3 Proposed measures for annual evaluation

\begin{tabular}{|l|l|}
\hline \multicolumn{1}{|c|}{ Measures } & \multicolumn{1}{c|}{ Meaning } \\
\hline Local offering \% & $\begin{array}{l}\text { Percentage of domestic products in regard to the total } \\
\text { products introduced in the market }\end{array}$ \\
\hline Collection intensity & Number of collection points divided by the population \\
\hline Collection rate & Collection amount divided by the domestic market \\
\hline Material recovery rate & $\begin{array}{l}\text { Fraction of materials reused and recycled (excluding } \\
\text { materials sent to energy recovery, landfilling, and } \\
\text { incineration) }\end{array}$ \\
\hline Reuse "high quality" rate & Fraction of collection amount (A) \\
\hline Reuse "low quality" rate & Fraction of collection amount (B) \\
\hline Recycling "product 1" rate & Fraction of collection amount (D) \\
\hline Recycling "product 2" rate & Fraction of collection amount (E) \\
\hline Energy recovery rate & Fraction of collection amount (F) \\
\hline $\begin{array}{l}\text { Landfilling/ incineration } \\
\text { rate }\end{array}$ & Fraction of collection amount (G) \\
\hline $\begin{array}{l}\text { Adjusted material recovery } \\
\text { rate }\end{array}$ & Summation of each [fraction*adjusted value] \\
\hline
\end{tabular}

\subsection{Research Delimitations and Future Opportunities}

Despite that the term "textile" has a wide focus, in this paper, I particularly address post-consumer clothing, linen, and shoes. In addition, more focus is given to clothing because my aim is not to describe all processes and technology used for recycling clothing, linen, and shoes; rather, I intend to develop new insight for the "clothing" case which can be applied for all other products in circular economy setting. This study doesn't address the efficiency and costeffectiveness of the practices under certain legislation. Thus, the study doesn't assess the efficiency of the EPR policy implementation in France. However, it highlights its benefits and limitations. Furthermore, it doesn't intend to improve the sorting and recycling technologies. It aims to develop a clear understanding 


\section{Original Contribution and Future Research}

to researchers and practitioners about the current circular economy paradigm to discover new approaches that can ensure economic, social and environmental benefits. Circular economy can have a wider scope that includes adopting clean energy to reduce environmental impact; however, examining such aspects are beyond the scope of this research.

Future researchers can address these limitations in the future and consider some of the research gaps identified. For instance, they might develop stylized economic models to assess some consequences resulting from the French EPR implementation for textile and clothing. In addition, more focus could be given to the PRO practices such as: How are material and financial flows monitored? How can better decisions be made on the tariff rate? How can different stakeholders engage together to support further collaboration? Do we need to dedicate an increased budget for R\&D? Finally, researchers can assess and test the measures and indicators proposed in this study to contribute to the circular economy development. 



\section{Chapter 7}

\section{CONCLUSION}

This dissertation has a multidisciplinary character that aims to elaborate on the current knowledge of sustainable development and circular economy through a thorough examination of post-consumer textile and clothing recovery. The textile and clothing industry faces severe challenges to overcome the need for economic, social, and environmental sustainability along the entire product life cycle. The study outlines some of these challenges attached to the current collection and reuse of post-consumer textile and clothing. Textile waste generation is increasing despite the fact that the material recovery rate of used textile can reach $90 \%$, on which $50 \%$ of it can be directly re-used. The practices of textile recovery have been examined to highlight several aspects of collection and recycling to provide the readers with sustainability issues that need to be considered for sustainable development. We further elaborate to discuss how to develop important measures to evaluate the sector circularity in our economy.

The current circular economy paradigm is focusing on extracting the maximum economic value from waste, not considering the flow of material, or 


\section{Chapter 7}

the global, social, and environmental impact on other economies. The circular economy doesn't have strong pillars to promote it, so it doesn't assure economic and environmental development. In addition, the claimed circular economy transition doesn't address the global supply chain sustainability and gives slight attention to the sustainable production and consumption goal. Establishing a central eco-organization for organizing the collection, transportation, and recycling of textile and other resources would turn the current society to innovative civilization. Efficient collection and transportation of textile waste can improve the society productivity and promote invaluable transportation cost and $\mathrm{CO} 2$ emission saving. The study shows that efficient textile collection and transportation for recycling can promote more than $70 \%$ savings of both transportation cost and carbon emissions. The linear programming model, despite its simplicity, can be used in practice to optimize the collection of used textile at the minimum logistics cost based on the location of existing recycling facilities. Future studies could focus on how to develop an organizational structure that encourages efficient collection and transportation for end-of-use resources. This dissertation provides a valuable insight on sustainability issues in the fashion industry and highlights a critical research gap and key aspects for promoting circular textile industry. 


\section{Bibliography}

American Apparel and Footwear Association (2017) ApparelStats and ShoeStats 2016 at-aglance Available at: https://www.aafaglobal.org/ AAFA/ApparelStats_and_ShoeStats_ata-glance.aspx (accessed 15 July 2017).

Ademe. 2016. Prévention de la production des déchets. [Prevention of waste production.] http://www.ademe.fr/sites/default/files/assets/documents/plaquette_a4_preventiondechets_web_v08_pap_v-sr.pdf.

AMORCE. 2017. Who are we? http://www.amorce.asso.fr/fr/qui-sommesnous/presentation/ Accessed June 2017.

Andersen, M.S. (2007), "An introductory note on the environmental economics of the circular economy", Sustainability Science, Vol. 2 No. 1, pp. 133-140.

Atasu A and Subramanian R (2012) Extended producer responsibility for e-waste: individual or collective producer responsibility? Production and Operations Management 21: 1042-1059.

Ballou, R.H. (2004), Business Logistics Management, 5th ed., Pearson/Prentice Hall, Upper Saddle River, N.J.

BBC News (2016) Why East Africa wants to ban second-hand clothing. Available at: www.bbc.com/news/world-africa-35706427 (accessed 15 June 2017).

Beasley J and Georgeson R (2014) Advancing resource efficiency in Europe indicators and waste policy scenarios to deliver a resource efficient and sustainable Europe. Available at: www.eeb.org/EEB/? LinkServID=4E9BB68D-5056-B741-DBCCE36ABD15F02F (accessed 15 October 2015).

Bertrand, J.W.M. and Fransoo, J.C. (2002), “Operations management research methodologies using quantitative modeling", International Journal of Operations \& Production Management, Vol. 22 No. 2, pp. 241-264.

Bloemhof-Ruwaard, J.M., Fleischmann, M. and Van Nunen, J.A. (1999), “Reviewing distribution issues in reverse logistics", New Trends in Distribution Logistics, Springer, pp. 23-44. 


\section{Bibliography}

de Brito, M.P., Carbone, V. and Blanquart, C.M. (2008), “Towards a sustainable fashion retail supply chain in Europe: Organisation and performance", International Journal of Production Economics, Vol. 114 No. 2, pp. 534-553.

de Brito, M.P. and Dekker, R. (2002), "A framework for reverse logistics", Econometric Institute Report EI2002-38, Erasmus University Rotterdam, The Netherlands.

Bureau of Labor Statistics (2016) Consumer expenditures. Available at: www.bls.gov/news.release/pdf/cesan.pdf (accessed 15 September 2017).

Caro, F. and V. Martínez-de-Albéniz. 2014. Fast fashion: Business model overview and research opportunities. In Agrawal, N. and Smith, S. A. (Eds.), Retail Supply Chain Management: Quantitative Models and Empirical Studies. Springer US, New York, Pp. 237-264.

Charonis, G.-K. (2012), “Degrowth, steady state economics and the circular economy: three distinct yet increasingly converging alternative discourses to economic growth for achieving environmental sustainability and social equity | Sustainability - Missing Points in the Development Dialogue", World Economics Association, available at: http:// sustainabilityconference2012.weaconferences.net/papers/degrowth-steady-stateeconomics-and-the-circular-economy-three-distinct-yet-increasingly-converging-alternativediscourses-to-economic-growth-for-achieving-environmental-sustainability-and-social-eq/ (accessed 1 March 2018).

China National Textile \& Apparel Council (2013) Chinese textile industry aims for 'green'. Available at: http://english.ctei.cn/innews/domes- tic/201308/t20130821_1595808.html (accessed 15 September 2017).

China's Ministry of Environmental Protection (2017) China's planned ban on imported scrap vexes an industry. Available at: http://english.mep. gov.cn/News_service/media_news/201707/t20170728_418690.shtml (accessed 15 November 2017).

Cline EL (2013) Overdressed: The Shockingly High Cost of Cheap Fashion. New York: Portfolio/Penguin.

Connaway, L.S. and Powell, R.R. (2010), Basic Research Methods for Librarians, 5th ed., Libraries Unlimited, Santa Barbara, Calif. 


\section{Bibliography}

WWF. (n.d.) Cotton farming. Available at:

http://wwf.panda.org/about_our_earth/about_freshwater/freshwater_problems/thirsty_c rops/cotton/ (accessed 1 January 2018).

Coughlan, P. and Coghlan, D. (2002), "Action research for operations management", International Journal of Operations \& Production Management, Vol. 22 No. 2, pp. 220-240.

Daugherty, P.J., Autry, C.W. and Ellinger, A.E. (2001), “Reverse logistics: The relationship between resource commitment and program performance", Journal of Business Logistics, Vol. 22 No. 1, pp. 107-124.

Dekker, R., Fleischmann, M., Inderfurth, K. and Van Wassenhove, L.N. (Eds.). (2004), Reverse Logistics, Springer Berlin Heidelberg, Berlin, Heidelberg, available at: https://doi.org/10.1007/978-3-540-24803-3.

Dowlatshahi, S. (2012), "A framework for the role of warehousing in Reverse Logistics", International Journal of Production Research, Vol. 50 No. January 2015, pp. 1265-1277.

Dubois M, de Graaf D and Thieren J (2016). Exploration of the role of extended producer responsibility for the circular economy in the Netherlands. EY, June. Available at: www.ey.com/Publication/vwLUAssets/ey-exploration-role- extended-producerresponsibility-for-circular-economy-netherlands/\$FILE/ ey-exploration-role-extendedproducer-responsibility-for-circular-economy- netherlands.pdf (accessed 15 November 2017).

EC (2002) Costs for municipal waste management in the EU (2002). Available at: http://ec.europa.eu/environment/waste/studies/pdf/eucost- waste.pdf (accessed 15 November 2017).

EC (2008) Directive 2008/98/EC of the European Parliament and of the Council of 19 November 2008 on waste and repealing certain directives. Brussels: European Commission.

EC (2015) Development of guidance on extended producer responsibility (EPR). Available at: http://ec.europa.eu/environment/archives/waste/ eu_guidance/introduction.html (accessed 15 November 2016).

EC. (2016), "Reducing CO2 emissions from Heavy-Duty Vehicles", Climate Action - European Commission, available at: https://ec.europa.eu/clima/policies/transport/vehicles/heavy_en (accessed 12 March 2018). 


\section{Bibliography}

EC (2016a) Waste. Introduction. Available at: http://ec.europa.eu/environment/waste/landfill_index.htm (accessed 15 November 2017).

EC (2016b) Waste. Review of waste policy and legislation. Available at: http://ec.europa.eu/environment/waste/target_review.htm (accessed 15 November 2017).

EC Eco-innovation (2017) Clothing project to explore the circular economy for textiles. Available at: https://ec.europa.eu/environment/ecoap/about- eco-innovation/goodpractices/eu/20140318-clothing-project-to-explore- the-circular-economy-for-textiles_en (accessed 15 November 2017).

Eco TLC (2015) Guide Practique: Collecter, trier, valoriser les TLC usagés sur mon territoire. Available at: www.ecotlc.fr/ressources/

Documents_site/Guide_Pratique_Collecte_TLC_usages.pdf (accessed 15 June 2015).

Eco TLC (2016a) 2016 at a glance: annual report. Available at: www.ecotlc. fr/ressources/Documents_site/2016_at_a_glance_BD.pdf (accessed 15 September 2017).

Eco TLC (2016b) Calculation of the contribution on quantities marketed. Available at: www.ecotlc.fr/page-287-calcul-de-la-strong-class-search- excerpt-contribution-strong-surles-quantites-mises-en-marche.html (accessed 15 June 2017).

Eco TLC (2017) Roads to innovation (2017). Available at: http://www.ecotlc. fr/ressources/Documents_site/6_2017_Roads-Innovation_GB_BD.pdf (accessed November 2017).

Ekström KM and Salomonson N (2014) Reuse and recycling of clothing and textiles: a network approach. Journal of Macromarketing 34: 383-399.

EPA (2014) Advancing sustainable materials management: facts and figures 2014. Available at: www.epa.gov/sites/production/files/2016-11/documents/2014_smm_tablesfigures_508.pdf (accessed 15 November 2017).

Esenduran G and Kemahlioglu-Ziya E (2015) A comparison of product take- back compliance schemes. Production and Operations Management 24: 71-88.

European Environmental Agency (2016) France fact sheet. Overview of national waste prevention programmes in Europe. Available at:

https: / / www.google.es $/$ url? sa=t\&rct=j\&q=\&esrc=s\&source=web\&cd=1\&ved=0ahUKEwiq pPDY9oTbAhVmOpoKHUEMCUoQFggnMAA\&url=https\%3A\%2F\%2Fwww.eea.europa.eu 


\section{Bibliography}

\%2Fthemes $\% 2$ Fwaste $\% 2$ Fwaste-prevention $\% 2$ Fcountries $\% 2$ France-waste-preventioncountry-fact-sheet\&usg=AOvVaw1bE7ETSoGKo1MO3uEWDdPE

European Parliament. (2016), “Circular economy package. Four legislative proposals on waste”, available at: http://www.europarl.europa.eu/EPRS/EPRS-Briefing-573936-Circulareconomy-package-FINAL.pdf (accessed 28 February 2018).

Eurostat (2015) Waste statistics. Available at: http:/ / ec.europa.eu/eurostat/statisticsexplained/index.php/Waste_statistics (accessed 15 January 2016).

Eurostat (2017) Population and population change. Table 1: Demographic balance 2016. Population 1st of January 2017. Available at: http://ec.europa. eu/eurostat/statisticsexplained/images/d/de/Population_and_popula- tion_change_statistics_YB2017.xlsx (accessed 15 November 2017).

Export.gov (2016) Philippines - prohibited \& restricted imports. Available at: www.export.gov/article?id=Philippines-Prohibited-Restricted-Imports (accessed 15 November 2017).

Fachverband Textilrecycling (2015) Study Consumption, Demand and Reuse of Clothing and Textiles in Germany. Available at: https://www.bvse.de/images/pdf/LeitfaedenBroschueren/150914_Textilstudie_2015.pdf (accessed 15 November 2017).

FashionUnited. 2016. UK fashion industry statistics. https://fashionunited.uk/uk-fashionindustry-statistics. Accessed November 2016.

Fernie, J. and Sparks, L. (Eds.). (2004), Logistics and Retail Management: Insights into Current Practice and Trends from Leading Experts, 2nd ed., Kogan Page, London; Sterling, VA.

Fernie, J., Sparks, L., \& McKinnon, C.A. (2010), “Retail Logistics in the UK: Past, Present and Future John Fernie", International Journal of Retail \& Distribution Management, Vol. 38 No. 11/12, pp. 894-914.

Fleischmann, M. (2001), Quantitative Models for Reverse Logistics, Springer, Berlin; New York.

Flynn, B.B. (2008), "Having it all: rigor versus relevance in supply chain management research", Journal of Supply Chain Management, Vol. 44 No. 2, pp. 63-67.

Forza, C. (2002), "Survey research in operations management: a process-based perspective", International Journal of Operations \& Production Management, Vol. 22 No. 2, pp. 152-194. 


\section{Bibliography}

Geoffrion, A.M. (1976), “The Purpose of Mathematical Programming is Insight, Not Numbers", Interfaces, Vol. 7 No. 1.

George BR, Bockarie A and Mcbride H (2006) Textile products produced from alternative fibers. In: Wang Y (ed) Recycling in Textiles. Cambridge, UK: Woodhead Publishing Ltd.

Georgiadis, P. and Vlachos, D. (2004), “Decision making in reverse logistics using system dynamics", Yugoslav Journal of Operations Research, Vol. 14 No. 2, pp. 259-272.

Ghisellini, P., Cialani, C. and Ulgiati, S. (2016), "A review on circular economy: the expected transition to a balanced interplay of environmental and economic systems", Journal of Cleaner Production, Vol. 114, pp. 11-32.

Global Fashion Agenda \& The Boston Consulting Group. (2017), "Pulse of the Fashion Industry", available at: http://globalfashionagenda.com/wpcontent/uploads/2017/05/Pulse-of-the-Fashion-Industry_2017.pdf (accessed 28 February 2018).

Goffin, K., Raja, J.Z., Claes, B., Szwejczewski, M. and Martinez, V. (2012), “Rigor in qualitative supply chain management research: Lessons from applying repertory grid technique", edited by Flint, D. International Journal of Physical Distribution \& Logistics Management, Vol. 42 No. 8/9, pp. 804-827.

Gouvernement.fr (2016) How French government works. Available at: www.gouvernement.fr/en/how-government-works (accessed November 2016).

Govindan, K., Soleimani, H. and Kannan, D. (2015), “Reverse logistics and closed-loop supply chain: A comprehensive review to explore the future", European Journal of Operational Research, Vol. 240 No. 3, pp. 603-626.

GreenPeace. (2012), “Greenpeace exposes hazardous chemicals in clothes sold by Zara, and other leading fashion brands", Greenpeace East Asia, available at: http://www.greenpeace.org/eastasia/press/releases/toxics/2012/toxic-chemicals-detoxzara/ (accessed 28 February 2018).

Guide, V.D.R. and Van Wassenhove, L.N. (2009), “OR FORUM-The Evolution of Closed-Loop Supply Chain Research", Operations Research, Vol. 57 No. 1, pp. 10-18.

Guiltinan, J.P. and Nwokoye, N.G. (1975), “Developing Distribution Channels and Systems in the Emerging Recycling Industries", International Journal of Physical Distribution, Vol. 6 No. 1, pp. 28-38. 


\section{Bibliography}

Haas, W., Krausmann, F., Wiedenhofer, D. and Heinz, M. (2015), “How Circular is the Global Economy? An Assessment of Material Flows, Waste Production, and Recycling in the European Union and the World in 2005: How Circular is the Global Economy?", Journal of Industrial Ecology, Vol. 19 No. 5, pp. 765-777.

Hawley J (2009) Understanding and improving textile recycling: a systems perspective. In: Blackburn RS (ed) Sustainable Textiles: Life Cycle and Environmental Impact. New York: Woodhead.

Hazen, B.T., Cegielski, C. and Hanna, J.B. (2011), “Diffusion of green supply chain management: Examining perceived quality of green reverse logistics", The International Journal of Logistics Management, Vol. 22, pp. 373-389.

Huang, Y. and Yang, M. (2014), “Reverse logistics innovation, institutional pressures and performance", Management Research Review, Vol. 37 No. 7, pp. 615-641.

I: CO. 2015. http://www.ico-spirit.com/en/ico-partners/. Accessed October 2015

Johnson A and Adler M (2017) Let's talk: textile waste. Available at: https:/ / recycle.com/textile-recycling/ (accessed 15 September 2017).

Kallis, G. (2011), “In defence of degrowth”, Ecological Economics, Vol. 70 No. 5, pp. 873-880.

Kao E (2015) ‘Buy Nothing Day' urges Hongkongers to shun shopping and fast-fashion to reduce textiles waste. Available at: www.scmp.com/news/ hong-kong/healthenvironment/article/1884017/buy-nothing-day-urges-hongkongers-shun-shopping (accessed 15 September 2017).

Krikke, H.R., Kooi, E.J. and Schuur, P.C. (1999), “Network design in reverse logistics: a quantitative model", New Trends in Distribution Logistics, Springer, pp. 45-61.

Kubania J (2015) How second-hand clothing donations are creating a dilemma for Kenya. The Guardian, 6 July. Available at: www.theguardian.com/ world/2015/jul/06/second-handclothing-donations-kenya (accessed 15 November 2017).

La Fédération de la Maille \& de la Lingerie. (2014) "On the textile recycling road", available at: http://www.lafederation.com/data/evenements_4c4be/fiche/5486/leaflet_recyclage_bf06f.pdf (accessed 3 November 2014) 


\section{Bibliography}

Le Relais (2017) Une entreprise pas comme les autres. Available at:

http://lerelais.org/decouvrir.php?page=entreprise_pas_comme_les_autres (accessed 15 November 2017).

Lee, J. E., Gen, M. and Rhee, K.-G. (2009), “Network model and optimization of reverse logistics by hybrid genetic algorithm", Computers \& Industrial Engineering, Elsevier Ltd, Vol. 56 No. 3, pp. 951-964.

Lee, M. (2009), “What's the most sustainable fabric? - The Ecologist", available at: http://www.theecologist.org/green_green_living/clothing/268798/whats_the_most_sustai nable_fabric.html (accessed 27 January 2015).

Legifrance (2008) Décret n 2008-602 du 25 juin 2008 relatif au recyclage et au traitement des déchets issus des produits textiles d'habillement, des chaus- sures ou du linge de maison neufs destinés aux ménages. Available at: www.legifrance.gouv.fr/affichTexte.do?cidTexte=JORFTEXT000019074839 (accessed 15 October 2017).

Legifrance (2015) Code de l'environnement - Article L541-10-3. Available at: www.legifrance.gouv.fr/affichCodeArticle.do?cidTexte=LEGITEXT 000006074220\&idArticle=LEGIARTI000006834459\&dateTexte=\&cate gorieLien=cid (accessed 15 November 2016).

Mayer S (2016) A second-hand clothing ban in East Africa? Available at: http:/ / africame.com/second-hand-clothing-ban-east-africa/ (accessed 15 June 2017).

Mentzer, J.T. (2008), “RIGOR_VERSUS_RELEVANCE_WHY_WO.pdf”, Journal of Supply Chain Management, Vol. 44 No. 2, pp. 72-77.

Miles, M.B., Huberman, A.M. and Saldaña, J. (2014), Qualitative Data Analysis: A Methods Sourcebook, Third edition., SAGE Publications, Inc, Thousand Oaks, Califorinia.

Ministère de l'Écologie, du Développement durable et de l'Énergie (2014) Textiles d'habillement, linge de maison et chaussures des ménages [Clothing textiles, linen and household shoes]. Available at: http://www.ademe.fr/sites/default/files/assets/documents/tlc-donnees-2014_8593.pdf

Mzikian, P. 2013. SOEX presentation at REINNOVA 2013. Waste management challenges within the framework of a green economy. $3^{\text {rd }}$ International conference on innovative municipal 


\section{Bibliography}

waste management and treatment, REINNOVA. www.reinnova.es/test/wpcontent/ponencias2013/03.02\%20-\%20P.Mzikian.pdf. Accessed December 2014.

Näslund, D. (2002), "Logistics needs qualitative research - especially action research", International Journal of Physical Distribution \& Logistics Management, Vol. 32 No. 5, p. 321.

Nelles, M., Grünes, J. and Morscheck, G. (2016), “Waste Management in Germany Development to a Sustainable Circular Economy?", Procedia Environmental Sciences, Vol. 35, pp. 6-14.

Norek, C.D. (2002), "Returns management: making order out of chaos", SUPPLY CHAIN MANAGEMENT REVIEW, V. 6, NO. 3 (MAY/JUNE 2002), P. 34-42: ILL.

OECD (2001) Extended Producer Responsibility. A Guidance Manual for Governments. Paris: Organisation for Economic Co-operation and Development.

OECD (2016) OECD environmental performance reviews: France 2016. Available at: www.keepeek.com/Digital-Asset-Management/oecd/environ ment/oecd-environmentalperformance-reviews-france-2016_9789264252714-en\#page19 (accessed 15 November 2017).

Omondi R (2016) East Africa doesn't want your used clothing. Available at: www.ethicalstylehunter.com/journal/east-africa-doesnt-want-your-used- clothing (accessed 15 June 2017).

Palm, D., M. Elander, D. Watson, N. Kiørboe, H. Salmenpera, H. Dahlbo, K. Moliis, K. Lyng, C. Valente, S. Gislason, H. Tekie, and T. Rydberg. 2014. Towards a Nordic textile strategy: Collecting, sorting, reuse and recycling of textiles. Paper no. 0908-6692 [ISBN 978-92-893-27947], Nordic Council of Ministers, Copenhagen.

Pedersen E and Andersen K (2013) The SocioLog.dx experience: a global expert study on sustainable fashion. Available at: http://mistrafuture fashion.com/wpcontent/uploads/2016/01/CBS-2014-01-23-Report- Project-1.pdf (accessed 15 July 2017).

Plambeck E and Wang Q (2009) Effects of e-waste regulation on new product introduction. Management Science 55: 333-347.

Pochampally, K.K., Nukala, S. and Gupta, S.M. (2009), Strategic Planning Models for Reverse and Closed-Loop Supply Chains, CRC Press/Taylor \& Francis, Boca Raton.

Ponce-cueto, E. and Carrasco-gallego, R. (2011), “Practices for Recovering Mobile Phones in Spain", Vol. 12 No. 2, pp. 104-114. 


\section{Bibliography}

Realff, M.J., Ammons, J.C. and Newton, D.J. (2004), “Robust reverse production system design for carpet recycling", IIE Transactions, Vol. 36 No. 8, pp. 767-776.

Recycling expert (2017, November 7). Personal Interview.

Robinson, D. E. 1961. The economics of fashion demand. The Quarterly Journal of Economics 75 (3): Pp. 376-398.

Business Wire (2016) Research and Markets: Global Clothing Market Demand and Forecast to 2020 - Detailed Analysis of Asia and Australasia Market. January, available at: https://www.businesswire.com/news/home/20160111005845/en/Research-MarketsGlobal-Clothing-Market-Demand-Forecast (accessed 10 January 2018).

Rogers, D.S., Melamed, B. and Lembke, R.S. (2012), “Modeling and analysis of reverse logistics", Journal of Business Logistics, Vol. 33 No. 2, pp. 107-117.

Rogers, D.S. and Tibben-Lembke, R.S. (1999), Going Backwards: Reverse Logistics Trends and Practices, Reverse Logistics Executive Council, Reno, Nev.

Rossi, P.H., Wright, J.D. and Anderson, A.B. (Eds.). (1983), Handbook of Survey Research, Academic Press, New York.

Sas, I. (2013), Logistics of Closed-Loop Textile Recycling.

Schneider, F., Kallis, G. and Martinez-Alier, J. (2010), “Crisis or opportunity? Economic degrowth for social equity and ecological sustainability. Introduction to this special issue", Journal of Cleaner Production, Vol. 18 No. 6, pp. 511-518.

Seuring, S.A. (2008), "Assessing the rigor of case study research in supply chain management", Supply Chain Management: An International Journal, Vol. 13 No. 2, pp. 128-137.

Şen, A. 2008. The US fashion industry: A supply chain review. International Journal of Production Economics 114(2): 571-593.

Seuring, S., and M. Müller. 2008. From a literature review to a conceptual framework for sustainable supply chain management. Journal of cleaner production 16(15): 1699-1710.

Sherburne A (2009) Achieving sustainable textiles: a designer's perspective. In: Blackburn RS (ed) Sustainable Textiles: Life Cycle and Environmental Impact. New York: Woodhead.

SOEX Group. 2014.

www.SOEXgroup.com/scripts/pages.php?ParentId=5\&LanguageId=1\&R=12. Accessed October 2014. 


\section{Bibliography}

Spengler, T., Püchert, H., Penkuhn, T. and Rentz, O. (1997), “Environmental integrated production and recycling management", Produktion Und Umwelt, Springer, pp. 239-257.

Stahel WR (2013) Policy for material efficiency: sustainable taxation as a departure from the throwaway society. Philosophical Transactions of the Royal Society of London A: Mathematical, Physical and Engineering Sciences 371: 20110567.

Stake R (1995) The Art of Case Study Research. Thousand Oaks, CA: SAGE Publications.

The Textile Magazine. (2013), “World fibre production grows to 82 million tonnes in 2012", available at: http://www.indiantextilemagazine.in/fibre/world-fibre-production-grows-to82-million-tonnes-in-2012/ (accessed 28 February 2018).

Tiard, L. 2013). The French EPR. Sustainability and producer responsibility in textiles. Mistra Future Fashion Symposium. Available at: www.mistrafuturefashion.com/en/media/news/Documents/Laurianne\%20Tiard \%2029\%2 0May\%202013.pdf. (accessed January 2015).

Time for change. (2017), “CO2 emissions for shipping of goods”, available at: http://timeforchange.org/co2-emissions-shipping-goods (accessed 12 March 2018).

United Nations. (2017), “The Sustainable Development Goals Report 2017”, available at: https://unstats.un.org/sdgs/files/report/2017/TheSustainableDevelopmentGoalsReport20 17.pdf (accessed 28 February 2018).

Velis, C.A. and Vrancken, K.C. (2015), Which Material Ownership and Responsibility in a Circular Economy? SAGE Publications Sage UK: London, England.

Venkatesh, V.G. (2010), “Reverse logistics: an imperative area of research for fashion supply chain", The IUP Journal of Supply Chain Management, Vol. 7 No. 1, pp. 77-89.

Voss, C., Tsikriktsis, N. and Frohlich, M. (2002), "Case research in operations management", International Journal of Operations \& Production Management, Vol. 22 No. 2, pp. 195-219.

WWF. (2018), "Cotton. Overview", World Wildlife Fund, available at: https://www.worldwildlife.org/industries/cotton (accessed 28 February 2018).

Weber S, Lynes JB, Young S (2016) Fashion interest as a driver for consumer textile waste management: reuse, recycle or disposal. International Journal of Consumer Studies 41 (2): 207-215. 


\section{Bibliography}

Wicker A (2016) Fast Fashion is creating an environmental crisis.

http://www.newsweek.com/2016/09/09/old-clothes-fashion-waste-crisis-494824.html. Accessed September 2017.

Wikner, J., \& Tang, O. (2008). "A structural framework for closed-loop supply chains". International Journal of Logistics Management, vol. 19, no. 3, pp. 344-366.

WRAP (2012) Valuing our clothes. Available at: www.wrap.org.uk/sites/ files/wrap/VoC\%20FINAL\%20online\%202012\%2007\%2011.pdf (accessed 15 December 2017).

Wrap (2013). Design for Longevity. Guidance on increasing the active life of clothing. Final report, May 2013.

http://www.wrap.org.uk/sites/files/wrap/Design\%20for\%20Longevity\%20Report_0.pdf Accessed June 2017.

Wright, R. Richey, R. G. Tokman, M. and Palmer, J. C. (2011) "Recycling and Reverse Logistics," Journal of Applied Business and Economics, Vol. 12, Iss. 5, pp. 9 - 20.

YarnsandFibers. (2015), "Cotton ginner face tough time with falling prices and shrinking profit margins", available at: http://www.yarnsandfibers.com/news/textile-news/cotton-ginnerface-tough-time-falling-prices-and-shrinking-profit-margins\#.WsOhFNPFKUx (accessed 3 April 2018).

Yin R (2013) Case study research: Design and Methods, $5^{\text {th }}$ Ed., Thousand Oaks: Sage publications.

Zamani, B., M. Svanström, G. Peters, and T. Rydberg. 2014. A carbon footprint of textile recycling. A case Study in Sweden. Journal of Industrial Ecology 19 (4): 676-687. 


\section{Appendix A}

Previous studies (Chapter 2) on textile sustainability found in SCOPUS database

\section{A.1 List of previous studies on textile sustainability}

\begin{tabular}{|c|c|c|c|}
\hline No & $\begin{array}{l}\text { Value Chain } \\
\text { Activity }\end{array}$ & Authors & Journal \\
\hline 3 & $\begin{array}{l}\text { Fibers } \\
\text { Production }\end{array}$ & $\begin{array}{l}\text { (Bitzer and Glasbergen, } \\
2010 ; \\
\text { Sanches et al., 2015; } \\
\text { Visser, Dargusch, et al., } \\
2015 ; \\
\text { Vitale et al., 2011) }\end{array}$ & $\begin{array}{l}\text { Journal of Business Ethics } \\
\text { International Journal of Clothing Science } \\
\text { and Technology } \\
\text { Journal of Cleaner Production } \\
\text { Sustainability }\end{array}$ \\
\hline 5 & & $\begin{array}{l}\text { (Amindoust and Saghafinia, } \\
\text { 2016; }\end{array}$ & The Journal of The Textile Institute \\
\hline 7 & & $\begin{array}{l}\text { Caviglia-Harris et al., 2003; } \\
\qquad \text { Jia et al., 2015; }\end{array}$ & $\begin{array}{l}\text { Ecological Economics } \\
\text { Sustainability }\end{array}$ \\
\hline 8 & & Kannan, 2018; & $\begin{array}{l}\text { International Journal of Production } \\
\text { Economics }\end{array}$ \\
\hline 9 & $\begin{array}{l}\text { Sourcing \& } \\
\text { Procurement }\end{array}$ & Kumar et al., 2014; & Resources, Conservation and Recycling \\
\hline 10 & & Normann et al., 2017; & $\begin{array}{l}\text { International Journal of Physical } \\
\text { Distribution \& Logistics Management }\end{array}$ \\
\hline 11 & & Shaw et al., 2012; & Expert Systems with Applications \\
\hline 12 & & Wilhelm et al., 2016; & $\begin{array}{l}\text { International Journal of Production } \\
\text { Economics }\end{array}$ \\
\hline 13 & & Winter and Lasch, 2016) & Journal of Cleaner Production \\
\hline 14 & & (Azuma and Fernie, 2003; & $\begin{array}{l}\text { Journal of Fashion Marketing and } \\
\text { Management: An International Journal }\end{array}$ \\
\hline 15 & Design & Clancy et al., 2015; & Journal of Cleaner Production \\
\hline 16 & & Curwen et al., 2013; & Clothing and Textiles Research Journal \\
\hline 17 & & De Angelis et al., 2017; & Journal of Cleaner Production \\
\hline
\end{tabular}




\section{Appendíx $\mathcal{A}$}

\begin{tabular}{|c|c|c|c|}
\hline No & $\begin{array}{l}\text { Value Chain } \\
\text { Activity }\end{array}$ & Authors & Journal \\
\hline 18 & & Gam and Banning, 2011; & Clothing and Textiles Research Journal \\
\hline 19 & & $\begin{array}{l}\text { Gurova and Morozova, } \\
2016\end{array}$ & Journal of Consumer Culture \\
\hline 20 & & Han et al., 2017; & Fashion Practice \\
\hline 21 & & Janigo and $\mathrm{Wu}, 2015$; & Fashion Practice \\
\hline 22 & & Jin Gam et al., 2009; & $\begin{array}{c}\text { International Journal of Clothing Science } \\
\text { and Technology }\end{array}$ \\
\hline 23 & & Jin Gam et al., 2011; & $\begin{array}{c}\text { International Journal of Clothing Science } \\
\text { and Technology }\end{array}$ \\
\hline 24 & & Leerberg et al., 2010; & Sustainable Development \\
\hline 25 & & Niinimäki and Hassi, 2011; & Journal of Cleaner Production \\
\hline 26 & & Pan et al., 2015; & International Journal of Design \\
\hline 27 & & Wang and Shen, 2017; & Sustainability \\
\hline 28 & & Young et al., 2004) & Clothing and Textiles Research Journal \\
\hline 29 & \multirow{11}{*}{$\begin{array}{l}\text { Fabric } \\
\text { production }\end{array}$} & (Ali et al., 2014; & Journal of Cleaner Production \\
\hline 30 & & Ashby, 2016; & Operations Management Research \\
\hline 31 & & Chan, 2011; & $\begin{array}{c}\text { Procedia - Social and Behavioral } \\
\text { Sciences }\end{array}$ \\
\hline 32 & & Hussain et al., 2015; & Journal of Cleaner Production \\
\hline 33 & & Khatri et al., 2015; & Journal of Cleaner Production \\
\hline 34 & & Moreira et al., 2015; & Journal of Cleaner Production \\
\hline 35 & & Noman et al., 2013; & Waste Management \& Research \\
\hline 36 & & Subic et al., 2012; & Sustainability \\
\hline 37 & & Xu et al., 2013, & Resources, Conservation and Recycling \\
\hline 38 & & Xu et al., 2016; & Journal of Cleaner Production \\
\hline 39 & & Zhang, 2017) & Sustainability \\
\hline
\end{tabular}


Appendix $\mathcal{A}$

\begin{tabular}{|c|c|c|c|}
\hline No & $\begin{array}{l}\text { Value Chain } \\
\text { Activity }\end{array}$ & Authors & Journal \\
\hline 40 & \multirow{13}{*}{ Retailing } & (de Brito et al., 2008; & $\begin{array}{l}\text { International Journal of Production } \\
\text { Economics }\end{array}$ \\
\hline 41 & & Corvellec and Stål, 2017; & Journal of Cleaner Production \\
\hline 42 & & Fowler and Hope, 2007; & Business Strategy and the Environment \\
\hline 43 & & Fulton and Lee, 2013; & $\begin{array}{l}\text { Journal of Fashion Marketing and } \\
\text { Management: An International Journal }\end{array}$ \\
\hline 44 & & Goworek et al., 2012; & $\begin{array}{l}\text { International Journal of Retail \& } \\
\text { Distribution Management }\end{array}$ \\
\hline 45 & & Hu et al., 2014; & Sustainability \\
\hline 46 & & Jung and Jin, 2014; & $\begin{array}{c}\text { International Journal of Consumer } \\
\text { Studies }\end{array}$ \\
\hline 47 & & Lueg et al., 2015; & Business Strategy and the Environment \\
\hline 48 & & $\mathrm{Na}$ and $\mathrm{Na}, 2015$ & $\begin{array}{c}\text { International Journal of Clothing Science } \\
\text { and Technology }\end{array}$ \\
\hline 49 & & Pedersen and Netter, 2015; & $\begin{array}{l}\text { Journal of Fashion Marketing and } \\
\text { Management: An International Journal }\end{array}$ \\
\hline 50 & & $\begin{array}{l}\text { Petersen and Riisberg, } \\
\text { 2017; }\end{array}$ & Fashion Practice \\
\hline 51 & & Styles et al., 2012; & Resources, Conservation and Recycling \\
\hline 52 & & Yang et al., 2017) & Sustainability \\
\hline 53 & \multirow{6}{*}{ Consumption } & (Armstrong et al., 2015, & Journal of Cleaner Production \\
\hline 54 & & Armstrong et al., 2016; & Sustainable Development \\
\hline 55 & & Bly et al., 2015; & $\begin{array}{c}\text { International Journal of Consumer } \\
\text { Studies }\end{array}$ \\
\hline 56 & & $\begin{array}{l}\text { Brosdahl and Carpenter, } \\
\qquad 2010\end{array}$ & $\begin{array}{l}\text { Journal of Textile and Apparel, } \\
\text { Technology and Management }\end{array}$ \\
\hline 57 & & Bubna and Norum, 2017; & $\begin{array}{l}\text { Journal of Fashion Marketing and } \\
\text { Management: An International Journal }\end{array}$ \\
\hline 58 & & Carey and Cervellon, 2014; & $\begin{array}{l}\text { Journal of Fashion Marketing and } \\
\text { Management: An International Journal }\end{array}$ \\
\hline
\end{tabular}




\section{Appendíx $\mathcal{A}$}

\begin{tabular}{|c|c|c|c|}
\hline No & $\begin{array}{l}\text { Value Chain } \\
\text { Activity }\end{array}$ & Authors & Journal \\
\hline 59 & & $\begin{array}{l}\text { Cervellon and Wernerfelt, } \\
\qquad 2012 ;\end{array}$ & $\begin{array}{c}\text { Journal of Fashion Marketing and } \\
\text { Management: An International Journal }\end{array}$ \\
\hline 60 & & Chi, 2015; & The Journal of The Textile Institute \\
\hline 61 & & Cowan and Kinley, 2014; & $\begin{array}{l}\text { International Journal of Consumer } \\
\text { Studies }\end{array}$ \\
\hline 62 & & $\begin{array}{l}\text { Druckman and Jackson, } \\
\qquad 2008 ;\end{array}$ & Ecological Economics \\
\hline 63 & & Ha-Brookshire, 2012; & Clothing and Textiles Research Journal \\
\hline 64 & & Halme et al., 2004; & Ecological Economics \\
\hline 65 & & Han and Chung, 2014; & Clothing and Textiles Research Journal \\
\hline 66 & & Harris et al., 2016; & $\begin{array}{c}\text { International Journal of Consumer } \\
\text { Studies }\end{array}$ \\
\hline 67 & & Henninger et al., 2017; & $\begin{array}{l}\text { Journal of Fashion Marketing and } \\
\text { Management: An International Journal }\end{array}$ \\
\hline 68 & & Hill and Lee, 2012; & $\begin{array}{l}\text { Journal of Fashion Marketing and } \\
\text { Management: An International Journal }\end{array}$ \\
\hline 69 & & Hill and Lee, 2015; & $\begin{array}{l}\text { Journal of Fashion Marketing and } \\
\text { Management: An International Journal }\end{array}$ \\
\hline 70 & & Jack, 2013; & $\begin{array}{c}\text { International Journal of Consumer } \\
\text { Studies }\end{array}$ \\
\hline 71 & & Joung, 2014; & $\begin{array}{l}\text { International Journal of Retail \& } \\
\text { Distribution Management }\end{array}$ \\
\hline 72 & & Jung and Jin, 2016a, & Sustainability \\
\hline 73 & & Jung and Jin, 2016b; & $\begin{array}{c}\text { International Journal of Consumer } \\
\text { Studies }\end{array}$ \\
\hline 74 & & Kang et al., 2013; & $\begin{array}{c}\text { International Journal of Consumer } \\
\text { Studies }\end{array}$ \\
\hline 75 & & Kong et al., 2016; & Journal of Global Fashion Marketing \\
\hline 76 & & Kruschwitz et al., 2014; & $\begin{array}{c}\text { International Journal of Consumer } \\
\text { Studies }\end{array}$ \\
\hline 77 & & Lang et al., 2013; & $\begin{array}{l}\text { International Journal of Consumer } \\
\text { Studies }\end{array}$ \\
\hline 78 & & Maddox et al., 2011; & Waste Management \\
\hline 79 & & Maria Ciasullo et al., 2017; & Sustainability \\
\hline 80 & & $\begin{array}{l}\text { Matthews and Rothenberg, } \\
\text { 2017; }\end{array}$ & $\begin{array}{c}\text { International Journal of Consumer } \\
\text { Studies }\end{array}$ \\
\hline
\end{tabular}


Appendix $\mathcal{A}$

\begin{tabular}{|c|c|c|c|}
\hline No & $\begin{array}{l}\text { Value Chain } \\
\text { Activity }\end{array}$ & Authors & Journal \\
\hline 81 & & McNeill and Moore, 2015; & $\begin{array}{c}\text { International Journal of Consumer } \\
\text { Studies }\end{array}$ \\
\hline 82 & & McQueen et al., 2017; & $\begin{array}{c}\text { International Journal of Consumer } \\
\text { Studies }\end{array}$ \\
\hline 83 & & Momberg et al., 2012; & $\begin{array}{c}\text { International Journal of Consumer } \\
\text { Studies }\end{array}$ \\
\hline 84 & & $\begin{array}{l}\text { Norum and Ha-Brookshire, } \\
\qquad 2011 ;\end{array}$ & Clothing and Textiles Research Journal \\
\hline 85 & & Olson, 2013; & $\begin{array}{c}\text { Journal of the Academy of Marketing } \\
\text { Science }\end{array}$ \\
\hline 86 & & Park et al., 2017; & Journal of Global Fashion Marketing \\
\hline 87 & & $\begin{array}{l}\text { Peirson-Smith and Evans, } \\
\qquad 2017\end{array}$ & Fashion Practice \\
\hline 88 & & Ritch, 2015; & $\begin{array}{l}\text { International Journal of Retail \& } \\
\text { Distribution Management }\end{array}$ \\
\hline 89 & & Ritch and Schröder, 2012; & $\begin{array}{c}\text { International Journal of Consumer } \\
\text { Studies }\end{array}$ \\
\hline 90 & & $\begin{array}{l}\text { Rothenberg and Matthews, } \\
\text { 2017; }\end{array}$ & $\begin{array}{l}\text { International Journal of Retail \& } \\
\text { Distribution Management }\end{array}$ \\
\hline 91 & & Sadachar et al., 2016; & Journal of Global Fashion Marketing \\
\hline 92 & & Schor, 2005; & Ecological Economics \\
\hline 93 & & Song and Ko, 2017; & $\begin{array}{c}\text { International Journal of Consumer } \\
\text { Studies }\end{array}$ \\
\hline 94 & & Sonnenberg et al., 2014; & Clothing and Textiles Research Journal \\
\hline 95 & & Visser et al., 2015; & Sustainability \\
\hline 96 & & Wei and Jung, 2017; & Sustainability \\
\hline 97 & & Yates and Evans, 2016) & Environmental Policy and Governance \\
\hline 98 & & (Abraham, 2011; & $\begin{array}{l}\text { Journal of Fashion Marketing and } \\
\text { Management: An International Journal }\end{array}$ \\
\hline 99 & & Arafat et al., 2015; & Journal of Cleaner Production \\
\hline 100 & Fnd-of-uce & Beh et al., 2016; & $\begin{array}{l}\text { Supply Chain Management: An } \\
\text { International Journal }\end{array}$ \\
\hline 101 & treatment & $\begin{array}{l}\text { Dissanayake and Sinha, } \\
\qquad 2015\end{array}$ & Resources, Conservation and Recycling \\
\hline 102 & & Farrant et al., 2010; & $\begin{array}{c}\text { The International Journal of Life Cycle } \\
\text { Assessment }\end{array}$ \\
\hline 103 & & Janigo et al., 2017; & Fashion Practice \\
\hline 104 & & Kant Hvass, 2014; & $\begin{array}{l}\text { Journal of Fashion Marketing and } \\
\text { Management: An International Journal }\end{array}$ \\
\hline
\end{tabular}


Appendix $\mathcal{A}$

\begin{tabular}{|c|c|c|c|}
\hline No & $\begin{array}{l}\text { Value Chain } \\
\text { Activity }\end{array}$ & Authors & Journal \\
\hline 105 & & Keith and Silies, 2015; & $\begin{array}{l}\text { International Journal of Retail \& } \\
\text { Distribution Management }\end{array}$ \\
\hline 106 & & Kim and Kim, 2016; & $\begin{array}{l}\text { Journal of Textile and Apparel, } \\
\text { Technology and Management }\end{array}$ \\
\hline 107 & & Norum, 2017; & Sustainability \\
\hline 108 & & O'Reilly and Kumar, 2016; & $\begin{array}{c}\text { The International Journal of Logistics } \\
\text { Management }\end{array}$ \\
\hline
\end{tabular}




\section{Appendix $\mathcal{A}$}

\section{A.2 Bibliography}

Abraham, N. (2011), "The apparel aftermarket in India - a case study focusing on reverse logistics", Journal of Fashion Marketing and Management: An International Journal, Vol. 15 No. 2, pp. 211-227.

Ali, S., Khatri, Z., Khatri, A. and Tanwari, A. (2014), “Integrated desizing-bleaching-reactive dyeing process for cotton towel using glucose oxidase enzyme", Journal of Cleaner Production, Vol. 66, pp. 562-567.

Amindoust, A. and Saghafinia, A. (2016), "Textile supplier selection in sustainable supply chain using a modular fuzzy inference system model", The Journal of The Textile Institute, pp. $1-9$.

Arafat, H.A., Jijakli, K. and Ahsan, A. (2015), “Environmental performance and energy recovery potential of five processes for municipal solid waste treatment", Journal of Cleaner Production, Vol. 105, pp. 233-240.

Armstrong, C.M., Niinimäki, K., Kujala, S., Karell, E. and Lang, C. (2015), “Sustainable productservice systems for clothing: exploring consumer perceptions of consumption alternatives in Finland", Journal of Cleaner Production, Vol. 97, pp. 30-39.

Armstrong, C.M., Niinimäki, K., Lang, C. and Kujala, S. (2016), “A Use-Oriented Clothing Economy? Preliminary Affirmation for Sustainable Clothing Consumption Alternatives: A Use-Oriented Clothing Economy?", Sustainable Development, Vol. 24 No. 1, pp. 18-31.

Ashby, A. (2016), “From global to local: reshoring for sustainability", Operations Management Research, Vol. 9 No. 3-4, pp. 75-88.

Azuma, N. and Fernie, J. (2003), "Fashion in the globalized world and the role of virtual networks in intrinsic fashion design", Journal of Fashion Marketing and Management: An International Journal, Vol. 7 No. 4, pp. 413-427.

Beh, L.-S., Ghobadian, A., He, Q., Gallear, D. and O’Regan, N. (2016), “Second-life retailing: a reverse supply chain perspective", edited by Kumar, Marlene Amorim, Arijit Bhatt, V.Supply Chain Management: An International Journal, Vol. 21 No. 2, pp. 259-272.

Bitzer, V. and Glasbergen, P. (2010), "Partnerships for Sustainable Change in Cotton: An Institutional Analysis of African Cases", Journal of Business Ethics, Vol. 93 No. S2, pp. 223-240.

Bly, S., Gwozdz, W. and Reisch, L.A. (2015), “Exit from the high street: an exploratory study of sustainable fashion consumption pioneers: Sustainable fashion consumption pioneers study", International Journal of Consumer Studies, Vol. 39 No. 2, pp. 125-135.

de Brito, M.P., Carbone, V. and Blanquart, C.M. (2008), "Towards a sustainable fashion retail supply chain in Europe: Organisation and performance", International Journal of Production Economics, Vol. 114 No. 2, pp. 534-553.

Brosdahl, D.J. and Carpenter, J.M. (2010), “Consumer knowledge of the environmental impacts of textile and apparel production, concern for the environment, and environmentally friendly consumption behavior", Journal of Textile and Apparel, Technology and Management, Vol. 6 No. 4. 


\section{Appendix $\mathcal{A}$}

Bubna, J.M. and Norum, P. (2017), “Male apparel disposal: case study of consignment versus donation", Journal of Fashion Marketing and Management: An International Journal, Vol. 21 No. 2, pp. 235-246.

Carey, L. and Cervellon, M.-C. (2014), “Ethical fashion dimensions: pictorial and auditory depictions through three cultural perspectives", Journal of Fashion Marketing and Management: An International Journal, Vol. 18 No. 4, pp. 483-506.

Caviglia-Harris, J.L., Kahn, J.R. and Green, T. (2003), “Demand-side policies for environmental protection and sustainable usage of renewable resources", Ecological Economics, Vol. 45 No. 1, pp. 119-132.

Cervellon, M. and Wernerfelt, A. (2012), "Knowledge sharing among green fashion communities online: Lessons for the sustainable supply chain", edited by Choi, T.Journal of Fashion Marketing and Management: An International Journal, Vol. 16 No. 2, pp. 176-192.

Chan, H.K. (2011), “Green process and product design in practice", Procedia - Social and Behavioral Sciences, Vol. 25, pp. 398-402.

Chi, T. (2015), "Consumer perceived value of environmentally friendly apparel: an empirical study of Chinese consumers", The Journal of The Textile Institute, Vol. 106 No. 10, pp. 1038-1050.

Clancy, G., Fröling, M. and Peters, G. (2015), “Ecolabels as drivers of clothing design”, Journal of Cleaner Production, Vol. 99, pp. 345-353.

Corvellec, H. and Stål, H.I. (2017), "Evidencing the waste effect of Product-Service Systems (PSSs)", Journal of Cleaner Production, Vol. 145, pp. 14-24.

Cowan, K. and Kinley, T. (2014), “Green spirit: consumer empathies for green apparel: Consumer empathies for green apparel", International Journal of Consumer Studies, Vol. 38 No. 5, pp. 493-499.

Curwen, L.G., Park, J. and Sarkar, A.K. (2013), “Challenges and Solutions of Sustainable Apparel Product Development: A Case Study of Eileen Fisher", Clothing and Textiles Research Journal, Vol. 31 No. 1, pp. 32-47.

De Angelis, M., Adıgüzel, F. and Amatulli, C. (2017), "The role of design similarity in consumers' evaluation of new green products: An investigation of luxury fashion brands", Journal of Cleaner Production, Vol. 141, pp. 1515-1527.

Dissanayake, G. and Sinha, P. (2015), "An examination of the product development process for fashion remanufacturing", Resources, Conservation and Recycling, Vol. 104, pp. 94-102.

Druckman, A. and Jackson, T. (2008), "Measuring resource inequalities: The concepts and methodology for an area-based Gini coefficient", Ecological Economics, Vol. 65 No. 2, pp. 242-252.

Dubois, M., Hoogmartens, R., Van Passel, S., Van Acker, K. and Vanderreydt, I. (2015), "Innovative market-based policy instruments for waste management: A case study on shredder residues in Belgium", Waste Management E Research, Vol. 33 No. 10, pp. 886893.

Farrant, L., Olsen, S.I. and Wangel, A. (2010), "Environmental benefits from reusing clothes”, The International Journal of Life Cycle Assessment, Vol. 15 No. 7, pp. 726-736.

Fowler, S.J. and Hope, C. (2007), "Incorporating sustainable business practices into company strategy", Business Strategy and the Environment, Vol. 16 No. 1, pp. 26-38. 


\section{Appendix $\mathcal{A}$}

Fulton, K. and Lee, S. (2013), "Assessing sustainable initiatives of apparel retailers on the internet", Journal of Fashion Marketing and Management: An International Journal, Vol. 17 No. 3, pp. 353-366.

Gam, H.J. and Banning, J. (2011), “Addressing Sustainable Apparel Design Challenges With Problem-Based Learning", Clothing and Textiles Research Journal, Vol. 29 No. 3, pp. 202215.

Goworek, H., Fisher, T., Cooper, T., Woodward, S. and Hiller, A. (2012), “The sustainable clothing market: an evaluation of potential strategies for UK retailers", edited by Wigley, S.M.International Journal of Retail \& Distribution Management, Vol. 40 No. 12, pp. 935-955.

Gurova, O. and Morozova, D. (2016), "A critical approach to sustainable fashion: Practices of clothing designers in the Kallio neighborhood of Helsinki", Journal of Consumer Culture, p. 146954051666822.

Ha-Brookshire, J.E. (2012), “Country of Parts, Country of Manufacturing, and Country of Origin: Consumer Purchase Preferences and the Impact of Perceived Prices", Clothing and Textiles Research Journal, Vol. 30 No. 1, pp. 19-34.

Halme, M., Jasch, C. and Scharp, M. (2004), “Sustainable homeservices? Toward household services that enhance ecological, social and economic sustainability", Ecological Economics, Vol. 51 No. 1-2, pp. 125-138.

Han, S.L.C., Chan, P.Y.L., Venkatraman, P., Apeagyei, P., Cassidy, T. and Tyler, D.J. (2017), "Standard vs. Upcycled Fashion Design and Production", Fashion Practice, Vol. 9 No. 1, pp. 69-94.

Han, T.-I. and Chung, J.-E. (2014), “Korean Consumers' Motivations and Perceived Risks Toward the Purchase of Organic Cotton Apparel", Clothing and Textiles Research Journal, Vol. 32 No. 4, pp. 235-250.

Harris, F., Roby, H. and Dibb, S. (2016), “Sustainable clothing: challenges, barriers and interventions for encouraging more sustainable consumer behaviour: Sustainable clothing", International Journal of Consumer Studies, Vol. 40 No. 3, pp. 309-318.

Henninger, C.E., Alevizou, P.J., Tan, J., Huang, Q. and Ryding, D. (2017), “Consumption strategies and motivations of Chinese consumers: The case of UK sustainable luxury fashion", Journal of Fashion Marketing and Management: An International Journal, Vol. 21 No. 3, pp. 419-434.

Hill, J. and Lee, H. (2012), "Young Generation Y consumers' perceptions of sustainability in the apparel industry", Journal of Fashion Marketing and Management: An International Journal, Vol. 16 No. 4, pp. 477-491.

Hill, J. and Lee, H.-H. (2015), "Sustainable brand extensions of fast fashion retailers", Journal of Fashion Marketing and Management: An International Journal, Vol. 19 No. 2, pp. 205-222.

Hu, Z.-H., Li, Q., Chen, X.-J. and Wang, Y.-F. (2014), “Sustainable Rent-Based Closed-Loop Supply Chain for Fashion Products", Sustainability, Vol. 6 No. 10, pp. 7063-7088.

Hussain, T., Tausif, M. and Ashraf, M. (2015), "A review of progress in the dyeing of ecofriendly aliphatic polyester-based polylactic acid fabrics", Journal of Cleaner Production, Vol. 108, pp. 476-483.

Jack, T. (2013), “Laundry routine and resource consumption in Australia: Laundry routines and consumption", International Journal of Consumer Studies, Vol. 37 No. 6, pp. 666-674. 


\section{Appendix $\mathcal{A}$}

Janigo, K.A. and Wu, J. (2015), “Collaborative Redesign of Used Clothes as a Sustainable Fashion Solution and Potential Business Opportunity", Fashion Practice, Vol. 7 No. 1, pp. 75-97.

Janigo, K.A., Wu, J. and DeLong, M. (2017), “Redesigning Fashion: An Analysis and Categorization of Women's Clothing Upcycling Behavior", Fashion Practice, Vol. 9 No. 2, pp. 254-279.

Jia, P., Govindan, K., Choi, T.-M. and Rajendran, S. (2015), “Supplier Selection Problems in Fashion Business Operations with Sustainability Considerations", Sustainability, Vol. 7 No. 2, pp. 1603-1619.

Jin Gam, H., Cao, H., Bennett, J., Helmkamp, C. and Farr, C. (2011), “Application of design for disassembly in men's jacket: A study on sustainable apparel design", International Journal of Clothing Science and Technology, Vol. 23 No. 2/3, pp. 83-94.

Jin Gam, H., Cao, H., Farr, C. and Heine, L. (2009), “C2CAD: a sustainable apparel design and production model", International Journal of Clothing Science and Technology, Vol. 21 No. 4, pp. 166-179.

Joung, H.-M. (2014), “Fast-fashion consumers' post-purchase behaviours”, International Journal of Retail \& Distribution Management, Vol. 42 No. 8, pp. 688-697.

Jung, S. and Jin, B. (2014), "A theoretical investigation of slow fashion: sustainable future of the apparel industry: A theoretical investigation of slow fashion", International Journal of Consumer Studies, Vol. 38 No. 5, pp. 510-519.

Jung, S. and Jin, B. (2016a), “Sustainable Development of Slow Fashion Businesses: Customer Value Approach", Sustainability, Vol. 8 No. 6, p. 540.

Jung, S. and Jin, B. (2016b), “From quantity to quality: understanding slow fashion consumers for sustainability and consumer education: From quantity to quality", International Journal of Consumer Studies, Vol. 40 No. 4, pp. 410-421.

Kang, J., Liu, C. and Kim, S.-H. (2013), “Environmentally sustainable textile and apparel consumption: the role of consumer knowledge, perceived consumer effectiveness and perceived personal relevance: Environmentally sustainable textile and apparel consumption", International Journal of Consumer Studies, Vol. 37 No. 4, pp. 442-452.

Kannan, D. (2018), "Role of multiple stakeholders and the critical success factor theory for the sustainable supplier selection process", International Journal of Production Economics, Vol. 195, pp. 391-418.

Kant Hvass, K. (2014), "Post-retail responsibility of garments - a fashion industry perspective", Journal of Fashion Marketing and Management: An International Journal, Vol. 18 No. 4, pp. 413-430.

Keith, S. and Silies, M. (2015), "New life luxury: upcycled Scottish heritage textiles", edited by Professor Alessandro Brun and Dr Ce, A.International Journal of Retail \& Distribution Management, Vol. 43 No. 10/11, pp. 1051-1064.

Khatri, A., Peerzada, M.H., Mohsin, M. and White, M. (2015), “A review on developments in dyeing cotton fabrics with reactive dyes for reducing effluent pollution", Journal of Cleaner Production, Vol. 87, pp. 50-57.

Kim, C.S. and Kim, K.R. (2016), "A Case Study Comparing Textile Recycling Systems of Korea and the UK to Promote Sustainability", Journal of Textile and Apparel, Technology and Management, Vol. 10 No. 1, available at: 


\section{Appendix $\mathcal{A}$}

http://ojs.cnr.ncsu.edu/index.php/JTATM/article/view/9716 (accessed 14 April 2018).

Kong, H.M., Ko, E., Chae, H. and Mattila, P. (2016), “Understanding fashion consumers' attitude and behavioral intention toward sustainable fashion products: Focus on sustainable knowledge sources and knowledge types", Journal of Global Fashion Marketing, Vol. 7 No. 2, pp. 103-119.

Kruschwitz, A., Karle, A., Schmitz, A. and Stamminger, R. (2014), “Consumer laundry practices in Germany: Consumer laundry practices in Germany", International Journal of Consumer Studies, Vol. 38 No. 3, pp. 265-277.

Kumar, D.T., Palaniappan, M., Kannan, D. and Shankar, K.M. (2014), "Analyzing the CSR issues behind the supplier selection process using ISM approach", Resources, Conservation and Recycling, Vol. 92, pp. 268-278.

Lang, C., Armstrong, C.M. and Brannon, L.A. (2013), "Drivers of clothing disposal in the US: An exploration of the role of personal attributes and behaviours in frequent disposal: Drivers of frequent clothing disposal", International Journal of Consumer Studies, Vol. 37 No. 6, pp. 706-714.

Leerberg, M., Riisberg, V. and Boutrup, J. (2010), “Design responsibility and sustainable design as reflective practice: an educational challenge", Sustainable Development, Vol. 18 No. 5, pp. 306-317.

Lueg, R., Pedersen, M.M. and Clemmensen, S.N. (2015), “The Role of Corporate Sustainability in a Low-Cost Business Model - A Case Study in the Scandinavian Fashion Industry: The Role of Corporate Sustainability in a Low-Cost Business Model", Business Strategy and the Environment, Vol. 24 No. 5, pp. 344-359.

Maddox, P., Doran, C., Williams, I.D. and Kus, M. (2011), “The role of intergenerational influence in waste education programmes: The THAW project", Waste Management, Vol. 31 No. 12, pp. 2590-2600.

Maria Ciasullo, Gennaro Maione, Carlo Torre and Orlando Troisi. (2017), “What about Sustainability? An Empirical Analysis of Consumers' Purchasing Behavior in Fashion Context", Sustainability, Vol. 9 No. 9, p. 1617.

Matthews, D. and Rothenberg, L. (2017), “An assessment of organic apparel, environmental beliefs and consumer preferences via fashion innovativeness: MATTHEWS and ROTHENBURG”, International Journal of Consumer Studies, Vol. 41 No. 5, pp. 526-533.

McNeill, L. and Moore, R. (2015), "Sustainable fashion consumption and the fast fashion conundrum: fashionable consumers and attitudes to sustainability in clothing choice: Sustainable fashion consumption and the fast fashion conundrum", International Journal of Consumer Studies, Vol. 39 No. 3, pp. 212-222.

McQueen, R.H., Batcheller, J.C., Moran, L.J., Zhang, H. and Hooper, P.M. (2017), "Reducing laundering frequency to prolong the life of denim jeans: Reducing laundering frequency", International Journal of Consumer Studies, Vol. 41 No. 1, pp. 36-45.

Momberg, D., Jacobs, B. and Sonnenberg, N. (2012), “The role of environmental knowledge in young female consumers' evaluation and selection of apparel in South Africa: Ecofriendly apparel behaviour", International Journal of Consumer Studies, Vol. 36 No. 4, pp. 408-415. 


\section{Appendix $\mathcal{A}$}

Moreira, N., de Santa-Eulalia, L.A., Aït-Kadi, D., Wood-Harper, T. and Wang, Y. (2015), “A conceptual framework to develop green textiles in the aeronautic completion industry: a case study in a large manufacturing company", Journal of Cleaner Production, Vol. 105, pp. 371-388.

$\mathrm{Na}, \mathrm{Y}$. and Na, D.K. (2015), "Investigating the sustainability of the Korean textile and fashion industry", International Journal of Clothing Science and Technology, Vol. 27 No. 1, pp. 2333.

Niinimäki, K. and Hassi, L. (2011), “Emerging design strategies in sustainable production and consumption of textiles and clothing", Journal of Cleaner Production, available at:https://doi.org/10.1016/j.jclepro.2011.04.020.

Noman, M., Batool, S.A. and Chaudhary, M.N. (2013), "Economic and employment potential in textile waste management of Faisalabad", Waste Management \& Research, Vol. 31 No. 5, pp. $485-493$.

Normann, U., Ellegaard, C. and Møller, M.M. (2017), “Supplier perceptions of distributive justice in sustainable apparel sourcing", International Journal of Physical Distribution $\mathcal{E}$ Logistics Management, Vol. 47 No. 5, pp. 368-386.

Norum, P. (2017), “Towards Sustainable Clothing Disposition: Exploring the Consumer Choice to Use Trash as a Disposal Option", Sustainability, Vol. 9 No. 7, p. 1187.

Norum, P.S. and Ha-Brookshire, J.E. (2011), “Consumer Trade-Off Analysis and Market Share Estimation for Selected Socially Responsible Product Attributes for Cotton Apparel", Clothing and Textiles Research Journal, Vol. 29 No. 4, pp. 348-362.

Olson, E.L. (2013), "It's not easy being green: the effects of attribute tradeoffs on green product preference and choice", Journal of the Academy of Marketing Science, Vol. 41 No. 2, pp. 171-184.

O'Reilly, S. and Kumar, A. (2016), “Closing the loop: An exploratory study of reverse readymade garment supply chains in Delhi NCR", The International Journal of Logistics Management, Vol. 27 No. 2, pp. 486-510.

Pan, Y., Roedl, D., Blevis, E. and Thomas, J.C. (2015), “Fashion thinking: Fashion practices and sustainable interaction design", International Journal of Design, Vol. 9 No. 1, pp. 53-66.

Park, H., Lee, M.-Y. and Koo, W. (2017), “The four faces of apparel consumers: Identifying sustainable consumers for apparel", Journal of Global Fashion Marketing, Vol. 8 No. 4, pp. 298-312.

Pedersen, E.R.G. and Netter, S. (2015), “Collaborative consumption: business model opportunities and barriers for fashion libraries", Journal of Fashion Marketing and Management: An International Journal, Vol. 19 No. 3, pp. 258-273.

Peirson-Smith, A. and Evans, S. (2017), "Fashioning Green Words and Eco Language: An Examination of the User Perception Gap for Fashion Brands Promoting Sustainable Practices", Fashion Practice, Vol. 9 No. 3, pp. 373-397.

Petersen, T.B. and Riisberg, V. (2017), “Cultivating User-ship? Developing a Circular System for the Acquisition and Use of Baby Clothing", Fashion Practice, Vol. 9 No. 2, pp. 214-234.

Ritch, E.L. (2015), “Consumers interpreting sustainability: moving beyond food to fashion”, International Journal of Retail \& Distribution Management, Vol. 43 No. 12, pp. 1162-1181. 


\section{Appendix $\mathcal{A}$}

Ritch, E.L. and Schröder, M.J. (2012), “Accessing and affording sustainability: the experience of fashion consumption within young families: Experience of fashion consumption", International Journal of Consumer Studies, Vol. 36 No. 2, pp. 203-210.

Rothenberg, L. and Matthews, D. (2017), “Consumer decision making when purchasing ecofriendly apparel", International Journal of Retail \& Distribution Management, Vol. 45 No. 4, pp. 404-418.

Sadachar, A., Feng, F., Karpova, E.E. and Manchiraju, S. (2016), “Predicting environmentally responsible apparel consumption behavior of future apparel industry professionals: The role of environmental apparel knowledge, environmentalism and materialism", Journal of Global Fashion Marketing, Vol. 7 No. 2, pp. 76-88.

Sanches, R.A., Marcicano, J.P.P., de Held, M.S.B., Guimarães, B.M.G., Alonso, R.S., Takamune, K.M., Duarte, A.Y.S., et al. (2015), “Organic cotton, lyocell and SPF: a comparative study", International Journal of Clothing Science and Technology, Vol. 27 No. 5, pp. 692-704.

Schor, J.B. (2005), "Prices and quantities: Unsustainable consumption and the global economy", Ecological Economics, Vol. 55 No. 3, pp. 309-320.

Shaw, K., Shankar, R., Yadav, S.S. and Thakur, L.S. (2012), “Supplier selection using fuzzy AHP and fuzzy multi-objective linear programming for developing low carbon supply chain", Expert Systems with Applications, Vol. 39 No. 9, pp. 8182-8192.

Song, S. and Ko, E. (2017), "Perceptions, attitudes, and behaviors toward sustainable fashion: Application of $\mathrm{Q}$ and Q-R methodologies: SONG and $\mathrm{KO}^{\prime \prime}$, International Journal of Consumer Studies, Vol. 41 No. 3, pp. 264-273.

Sonnenberg, N., Jacobs, B. and Momberg, D. (2014), “The Role of Information Exposure in Female University Students' Evaluation and Selection of Eco-Friendly Apparel in the South African Emerging Economy", Clothing and Textiles Research Journal, Vol. 32 No. 4, pp. 266-281.

Styles, D., Schoenberger, H. and Galvez-Martos, J.-L. (2012), “Environmental improvement of product supply chains: A review of European retailers' performance", Resources, Conservation and Recycling, Vol. 65, pp. 57-78.

Subic, A., Shabani, B., Hedayati, M. and Crossin, E. (2012), “Capability Framework for Sustainable Manufacturing of Sports Apparel and Footwear", Sustainability, Vol. 4 No. 9, pp. 2127-2145.

Visser, F., Dargusch, P., Smith, C. and Grace, P.R. (2015), “Application of the Crop Carbon Progress Calculator in a 'farm to ship' cotton production case study in Australia", Journal of Cleaner Production, Vol. 103, pp. 675-684.

Visser, M., Gattol, V. and Helm, R. (2015), “Communicating Sustainable Shoes to Mainstream Consumers: The Impact of Advertisement Design on Buying Intention", Sustainability, Vol. 7 No. 7, pp. 8420-8436.

Vitale, J., Ouattarra, M. and Vognan, G. (2011), “Enhancing Sustainability of Cotton Production Systems in West Africa: A Summary of Empirical Evidence from Burkina Faso", Sustainability, Vol. 3 No. 8, pp. 1136-1169.

Wang, L. and Shen, B. (2017), "A Product Line Analysis for Eco-Designed Fashion Products: Evidence from an Outdoor Sportswear Brand", Sustainability, Vol. 9 No. 7, p. 1136. 


\section{Appendix $\mathcal{A}$}

Wilhelm, M., Blome, C., Wieck, E. and Xiao, C.Y. (2016), “Implementing sustainability in multitier supply chains: Strategies and contingencies in managing sub-suppliers", International Journal of Production Economics, Vol. 182, pp. 196-212.

Winter, S. and Lasch, R. (2016), “Environmental and social criteria in supplier evaluation Lessons from the fashion and apparel industry", Journal of Cleaner Production, Vol. 139, pp. 175-190.

Xiaoyong Wei and Sojin Jung. (2017), “Understanding Chinese Consumers' Intention to Purchase Sustainable Fashion Products: The Moderating Role of Face-Saving Orientation", Sustainability, Vol. 9 No. 9, p. 1570.

Xu, L., Mathiyazhagan, K., Govindan, K., Noorul Haq, A., Ramachandran, N.V. and Ashokkumar, A. (2013), "Multiple comparative studies of Green Supply Chain Management: Pressures analysis", Resources, Conservation and Recycling, Vol. 78, pp. 2635.

Xu, S., Chen, J., Wang, B. and Yang, Y. (2016), “An environmentally responsible polyester dyeing technology using liquid paraffin", Journal of Cleaner Production, Vol. 112, pp. 987-994.

Yang, S., Song, Y. and Tong, S. (2017), "Sustainable Retailing in the Fashion Industry: A Systematic Literature Review", Sustainability, Vol. 9 No. 7, p. 1266.

Yates, L. and Evans, D. (2016), “Dirtying Linen: Re-evaluating the sustainability of domestic laundry: Dirtying Linen: Re-Evaluating the Sustainability of Domestic Laundry", Environmental Policy and Governance, Vol. 26 No. 2, pp. 101-115.

Young, C., Jirousek, C. and Ashdown, S. (2004), “Undesigned: A study in sustainable design of apparel using post-consumer recycled clothing", Clothing and Textiles Research Journal, Vol. 22 No. 1-2, pp. 61-68.

Zabaniotou, A. and Andreou, K. (2010), “Development of alternative energy sources for GHG emissions reduction in the textile industry by energy recovery from cotton ginning waste", Journal of Cleaner Production, Vol. 18 No. 8, pp. 784-790.

Zaccariello, L., Cremiato, R. and Mastellone, M.L. (2015), “Evaluation of municipal solid waste management performance by material flow analysis: Theoretical approach and case study", Waste Management \& Research, Vol. 33 No. 10, pp. 871-885.

Zhang, R. (2017), "Sustainable Scheduling of Cloth Production Processes by Multi-Objective Genetic Algorithm with Tabu-Enhanced Local Search", Sustainability, Vol. 9 No. 10, p. 1754 . 


\section{Appendix B}

The Behavior of the Proposed MILP Model (Chapter 5)

\section{B.1 Model sample}

A model sample is represented below. Data (supply, capacity, and demand) for potential storage sites, recycling facilities, and the secondary markets should be considered to reach the optimum flow of materials from point of origin to point of consumption.

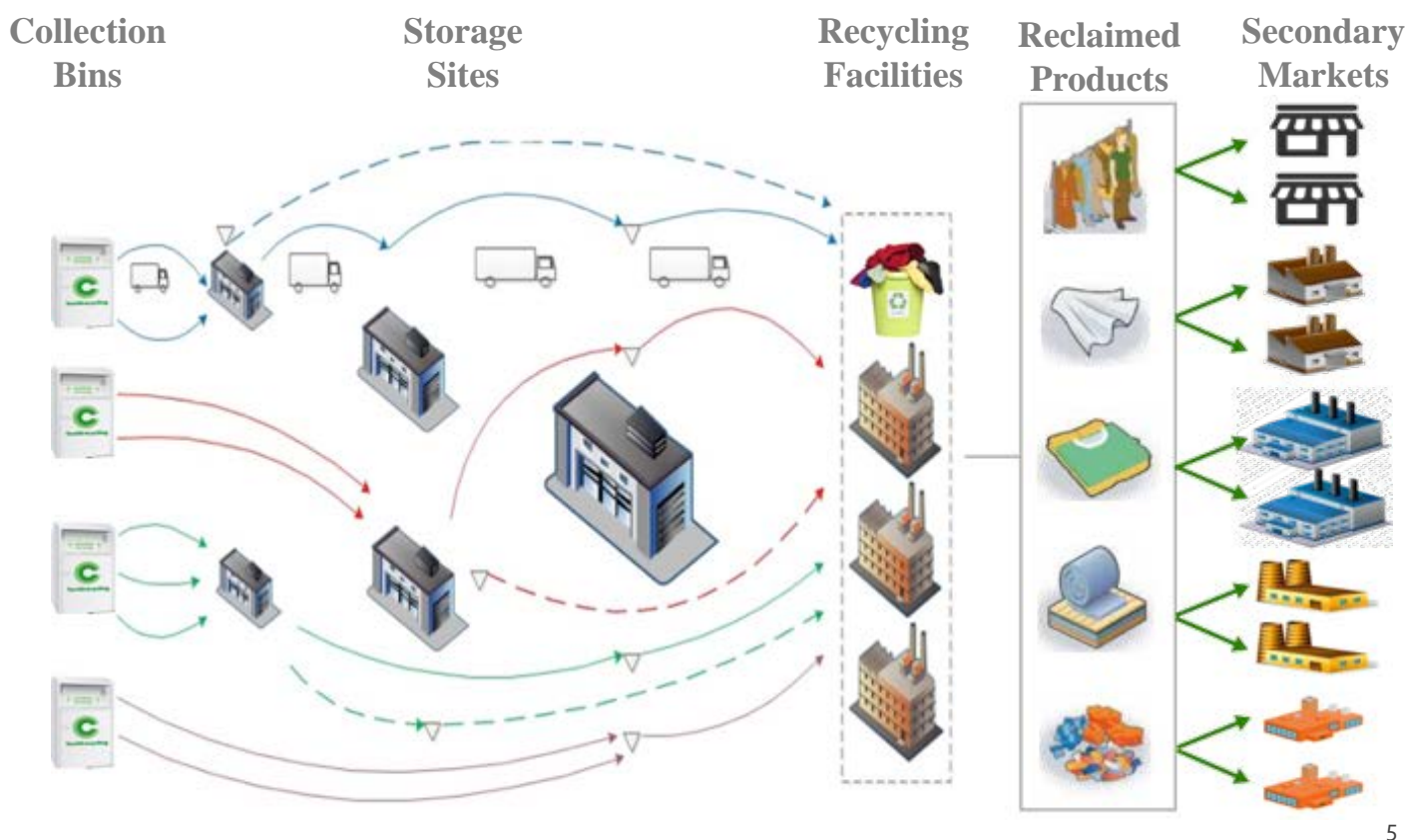

We simplify the model using 3 collection zones, 1 potential storage site, 2 recycling facilities, and 2 markets for each recycling channels (see below).

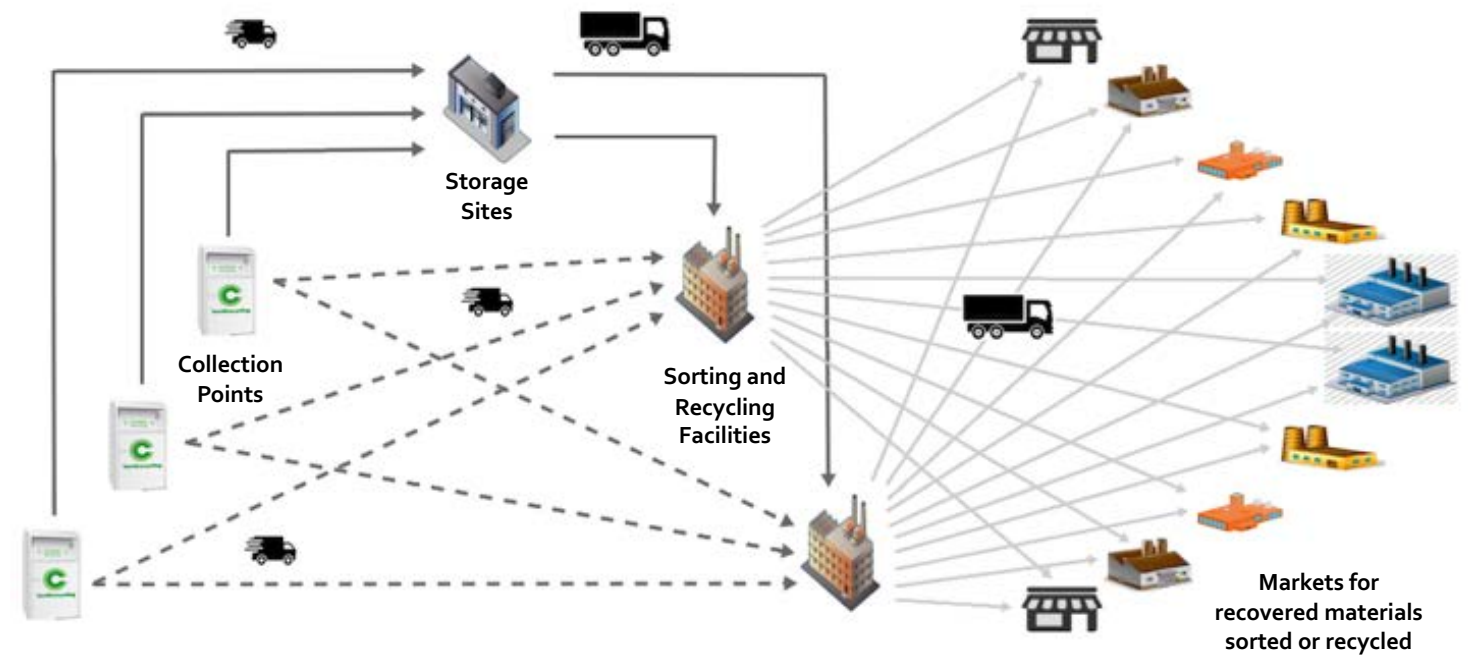




\section{Appendix $\mathcal{B}$}

\section{B.2 Model testing}

The model has been tested using the data shown in figure below.

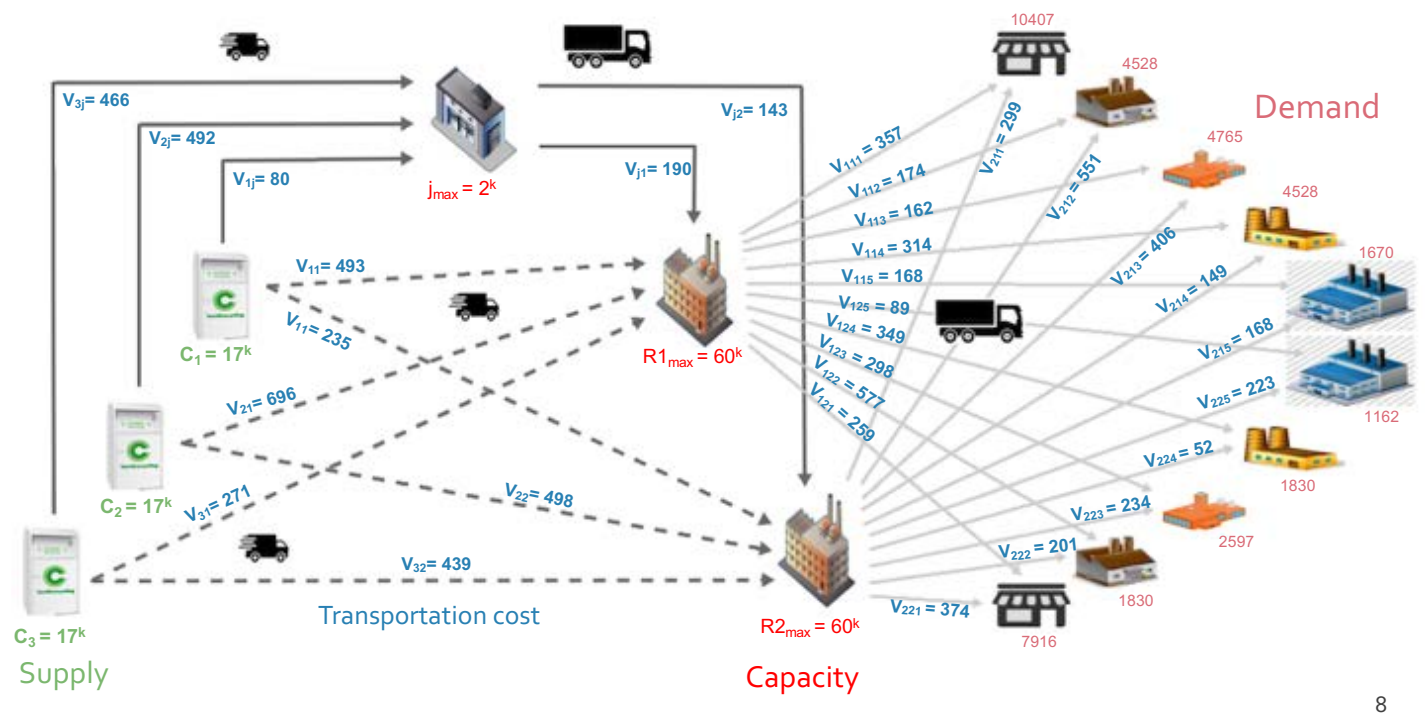

\section{B.3 Model solution}

The model then has been solved using python programming language and represented in the figure below. The proportions for the recycled materials, which have been considered while solving the model, are also highlighted (in red) in the Figure.

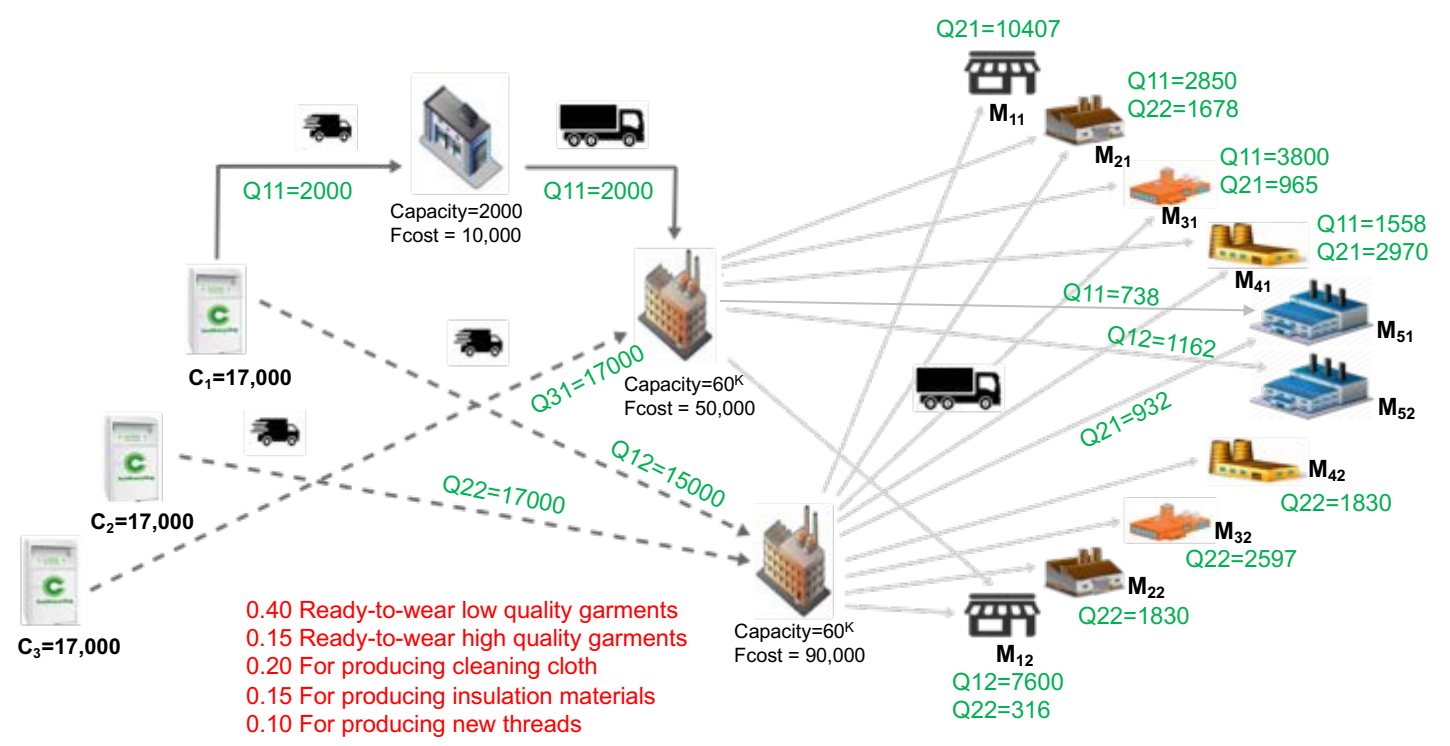




\section{B.4 Python programming code}

from coopr.pyomo import *

model $=$ AbstractModel ()

"'Input: Number of nodes for each level"'

\# Number of collection points (data file)

model. $c=$ Param $($ within $=$ NonNegativeIntegers $)$

\# indices for available collection points

model .collect $=$ RangeSet $(1$, model.$c)$

\# Number of storage sites (data file)

model.s $=$ Param (within $=$ NonNegativeIntegers)

\# indices for available storage sites

model.store $=$ RangeSet $(1$, model.s $)$

\# Number of recycling facilities (data file)

model. $\mathrm{p}=$ Param (within $=$ NonNegativeIntegers)

\# indices for available facilities

model.recycle $=$ RangeSet $(1$, model.p)

\# Number of markets for product 1 (data file)

model.m1 = Param(within=NonNegativeIntegers)

\# indices for available plants

model.sell1 = RangeSet $(1$, model.m1 $)$

\# Number of markets for product 2 (data file)

model.m2 = Param(within=NonNegativeIntegers)

\# indices for available plants

model.sell2 = RangeSet $(1$, model.m2 $)$

\# Number of markets for product 3 (data file)

model.m3 = Param(within=NonNegativeIntegers)

\# indices for available plants

model.sell3 = RangeSet $(1$, model.m3)

\# Number of markets for product 4 (data file)

model.m4 = Param(within=NonNegativeIntegers)

\# indices for available plants

model.sell4 = RangeSet(1, model.m4)

\# Number of markets for product 5 (data file)

model.m5 = Param(within=NonNegativeIntegers)

\# indices for available plants

model.sell5 = RangeSet(1, model.m5)

\# Number of re-distribution channels (data file)

model.ch $=$ Param (within=PositiveReals)

\# indices for available products

model.products $=$ RangeSet $(1$, model.ch $)$ 


\section{Appendix $\mathcal{B}$}

"'Input Data: Annual capacity and demand at each node"'
\# Capacity limit for each collection point(data file)
model.cap_collect = Param(model.collect, within=PositiveReals)
\# Capacity limit for each plant(data file)
model.cap_store = Param(model.store, within=PositiveReals)
\# Capacity limit for each plant(data file)
model.cap_recycle = Param(model.recycle, within=PositiveReals)
\# Min Product Demand at each market (data file)
model.M1min_demand = Param(model.sell1, within=PositiveReals)
model.M2min_demand = Param(model.sell2, within=PositiveReals)
model.M3min_demand = Param(model.sell3, within=PositiveReals)
model.M4min_demand = Param(model.sell4, within=PositiveReals)
model.M5min_demand = Param(model.sell5, within=PositiveReals)

\# Max Product Demand at each market (data file)

model.M1max_demand = Param(model.sell1, within=PositiveReals)

model.M2max_demand $=$ Param $($ model. sell2, within=PositiveReals $)$

model.M3max_demand $=$ Param $($ model. sell3, within=PositiveReals $)$

model.M4max_demand $=$ Param $($ model.sell4, within=PositiveReals $)$

model.M5max_demand $=$ Param $($ model.sell5, within=PositiveReals)

"'Input Data: Transportation Cost"'

\# Transportation cost from collection point $\mathrm{i}$ to storage site $\mathrm{j}$ (Data file)

model.transCost 1 = Param(model.collect, model.store, within=PositiveReals)

\# Transportation cost from collection point i to recycling plant $\mathrm{k}$ (Data file)

model.transCost $2=$ Param(model.collect, model.recycle, within=PositiveReals)

\# Transportation cost from storage site $\mathrm{j}$ to recycling plant $\mathrm{k}$ (Data file)

model.transCost 3 = Param(model.store, model.recycle, within=PositiveReals)

\# Transportation cost of product 1 from recycling plant $\mathrm{k}$ to demand market 1 (Data file) model.transCost41 = Param(model.recycle, model.sell1, within=PositiveReals)

\# Transportation cost of product 2 from recycling plant $\mathrm{k}$ to demand market 2 (Data file) model.transCost42 = Param(model.recycle, model.sell2, within=PositiveReals)

\# Transportation cost of product 3 from recycling plant $\mathrm{k}$ to demand market 3 (Data file) model.transCost43 = Param(model.recycle, model.sell3, within=PositiveReals)

\# Transportation cost of product 4 from recycling plant $\mathrm{k}$ to demand market 4 (Data file) model.transCost44 = Param(model.recycle, model.sell4, within=PositiveReals)

\# Transportation cost of product 5 from recycling plant $\mathrm{k}$ to demand market 5 (Data file) model.transCost45 = Param(model.recycle, model.sell5, within=PositiveReals) 


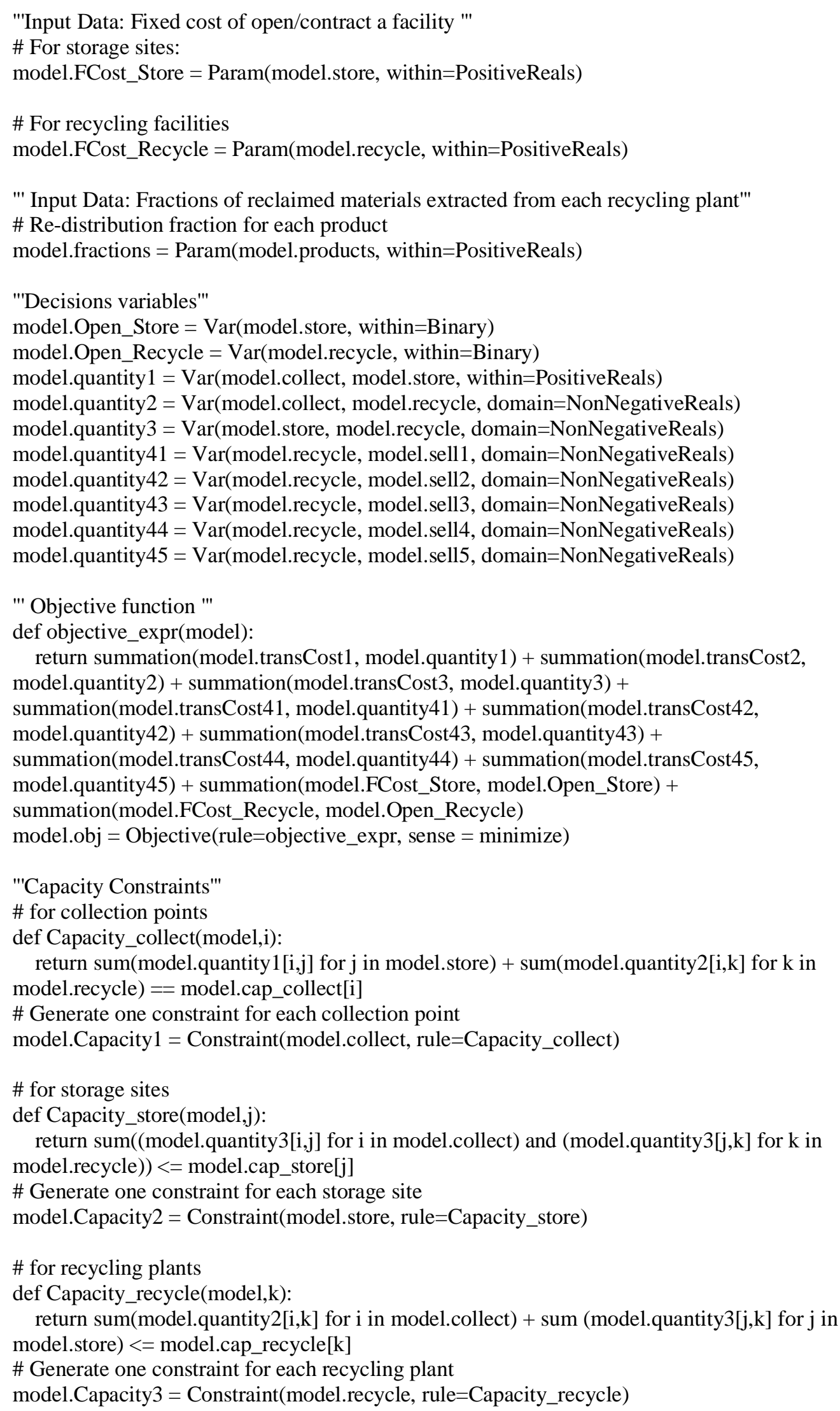




\section{Appendix $\mathcal{B}$}

"'Materials capacity constraints'"
\# For product 1
def Capacity_product1(model, k):

return sum(model.quantity $41[\mathrm{k}, 1]$ for 1 in model.sell1) $<=0.4 *(\operatorname{sum}$ (model.quantity $3[\mathrm{j}, \mathrm{k}]$

for $\mathrm{j}$ in model.store) + sum(model.quantity2 $[\mathrm{i}, \mathrm{k}]$ for $\mathrm{i}$ in model.collect))

model.Capacity $41=$ Constraint $($ model.recycle, rule=Capacity_product1)

\# For product 2

def Capacity_product2(model, k):

return sum(model.quantity $42[\mathrm{k}, \mathrm{l}]$ for $\mathrm{l}$ in model.sell1) $<=0.15 *(\operatorname{sum}($ model.quantity $3[\mathrm{j}, \mathrm{k}]$

for $\mathrm{j}$ in model.store) + sum(model.quantity2[i,k] for $\mathrm{i}$ in model.collect))

model.Capacity $42=$ Constraint(model.recycle, rule=Capacity_product 2 )

\# For product 3

def Capacity_product3(model, $\mathrm{k}$ ):

return sum(model.quantity $43[\mathrm{k}, 1]$ for 1 in model.sell1) $<=0.2 *(\operatorname{sum}($ model.quantity $3[\mathrm{j}, \mathrm{k}]$

for $\mathrm{j}$ in model.store) + sum(model.quantity $2[\mathrm{i}, \mathrm{k}]$ for $\mathrm{i}$ in model.collect))

model.Capacity43 $=$ Constraint(model.recycle, rule=Capacity_product3)

\# For product 4

def Capacity_product4(model, k):

return sum(model.quantity $44[\mathrm{k}, \mathrm{l}]$ for $\mathrm{l}$ in model.sell1) $<=0.15 *(\operatorname{sum}$ (model.quantity $3[\mathrm{j}, \mathrm{k}]$

for $\mathrm{j}$ in model.store) + sum(model.quantity2[i,k] for $\mathrm{i}$ in model.collect))

model.Capacity44 $=$ Constraint(model.recycle, rule=Capacity_product4)

\# For product 5

def Capacity_product5(model, k):

return sum(model.quantity $45[\mathrm{k}, 1]$ for 1 in model.sell1) $<=0.1 *(\operatorname{sum}$ (model.quantity $3[\mathrm{j}, \mathrm{k}]$

for $\mathrm{j}$ in model.store) + sum(model.quantity2[i,k] for $\mathrm{i}$ in model.collect))

model.Capacity $45=$ Constraint(model.recycle, rule=Capacity_product5) 
"' Market Demand Constraints"'
\# Minimum demand for product 1
def Min_Demand1(model,l):

return sum(model.quantity $41[\mathrm{k}, 1]$ for $\mathrm{k}$ in model.recycle) $>=$ model.M1min_demand[1]

\# Generate one constraint for each market

model.Demand $1 \mathrm{~min}=$ Constraint $($ model.sell1, rule=Min_Demand 1$)$

\# Maximum demand for product 1

def Max_Demand1(model,1):

return sum(model.quantity41[k,1] for $\mathrm{k}$ in model.recycle) $<=$ model.M1max_demand[1]

\# Generate one constraint for each market

model.Demand $1 \max =$ Constraint $($ model.sell1, rule=Max_Demand 1$)$

\# Minimum demand for product 2

def Min_Demand2(model,1):

return sum(model.quantity42[k,1] for $\mathrm{k}$ in model.recycle) $>=$ model.M2min_demand[1]

\# Generate one constraint for each market

model.Demand2 $\min =$ Constraint $($ model.sell2, rule=Min_Demand2 $)$

\# Max demand for product 2

def Max_Demand2(model,1):

return sum(model.quantity42[k,1] for $\mathrm{k}$ in model.recycle) $>=$ model.M2max_demand[1]

\# Generate one constraint for each market

model.Demand2 $\max =$ Constraint $($ model.sell2, rule=Max_Demand2 $)$

\# Minimum demand for product 3

def Min_Demand3(model,1):

return sum(model.quantity43[k,l] for $\mathrm{k}$ in model.recycle) $>=$ model.M3min_demand[1]

\# Generate one constraint for each market

model.Demand $3 \mathrm{~min}=$ Constraint $($ model.sell3, rule=Min_Demand3 $)$

\# Max demand for product 3

def Max_Demand3(model,1):

return sum(model.quantity43[k,1] for $\mathrm{k}$ in model.recycle) $>=$ model.M3max_demand[1]

\# Generate one constraint for each market

model.Demand $3 \max =$ Constraint $($ model.sell3, rule=Max_Demand3 $)$

\# Minimum demand for product 4

def Min_Demand4(model,1):

return sum(model.quantity44[k,l] for $\mathrm{k}$ in model.recycle) $>=$ model.M4min_demand[1]

\# Generate one constraint for each market

model.Demand $4 \min =$ Constraint $($ model.sell4, rule=Min_Demand4 $)$

\# Max demand for product 4

def Max_Demand4(model,1):

return sum(model.quantity $44[\mathrm{k}, 1]$ for $\mathrm{k}$ in model.recycle) $>=$ model.M4max_demand[1]

\# Generate one constraint for each market

model.Demand $4 \max =$ Constraint $($ model.sell4, rule=Max_Demand4)

\# Minimum demand for product 5

def Min_Demand5(model,1):

return sum(model.quantity45[k,l] for $\mathrm{k}$ in model.recycle) $>=$ model.M5min_demand[1]

\# Generate one constraint for each market

model.Demand5 $\min =$ Constraint $($ model.sell5, rule=Min_Demand5 $)$

\# Max demand for product 5

def Max_Demand5(model,1):

return sum(model.quantity $45[\mathrm{k}, \mathrm{l}]$ for $\mathrm{k}$ in model.recycle) $>=$ model.M5max_demand[1]

\# Generate one constraint for each market

model.Demand5max $=$ Constraint $($ model.sell5, rule=Max_Demand5) 


\section{Appendix $\mathcal{B}$}

"'Flow Conservation Constraints"'

\# Linking constraint for the storage sites

def BalanceS(model,j):

return sum(model.quantity $1[\mathrm{i}, \mathrm{j}]$ for $\mathrm{i}$ in model.collect) - sum(model.quantity $3[\mathrm{j}, \mathrm{k}]$ for $\mathrm{k}$ in model.recycle $)==0$

model.Balance $1=$ Constraint $($ model.store, rule $=$ BalanceS $)$

\# Linking constraint for recycling facilities

def BalanceR(model,k):

return sum(model.quantity $3[\mathrm{j}, \mathrm{k}]$ for $\mathrm{j}$ in model.store) $+\operatorname{sum}($ model.quantity $2[\mathrm{i}, \mathrm{k}]$ for $\mathrm{i}$ in model.collect $)==\operatorname{sum}($ model.quantity $41[\mathrm{k}, 1]$ for 1 in model.sell1 $)+\operatorname{sum}($ model.quantity $42[\mathrm{k}, 1]$ for 1 in model.sell2) + sum(model.quantity $43[\mathrm{k}, 1]$ for 1 in model.sell 3$)+$ sum(model.quantity44[k,1] for 1 in model.sell4) + sum(model.quantity45[k,1] for 1 in model.sell5) model.Balance 2 = Constraint $($ model.recycle, rule $=$ BalanceR $)$

"'Logical Constraints for opening/contracting a facility"'

\# For storage sites

def Logical_Store(model,j):

return sum(model.quantity1[i,j] for i in model.collect) $<=1000000 *$ model.Open_Store[j]

model.logical_s = Constraint(model.store, rule=Logical_Store)

\# For recycling facilities

def Logical_Recycle(model,k):

return sum(model.quantity $2[\mathrm{i}, \mathrm{k}]$ for $\mathrm{i}$ in model.collect)+ $\operatorname{sum}(\operatorname{model}$.quantity $3[\mathrm{j}, \mathrm{k}]$ for $\mathrm{j}$ in model.store) $<=1000000 *$ model.Open_Recycle[k]

model.logical_r $=$ Constraint(model.recycle, rule=Logical_Recycle) 



\section{Curriculum Vitae}

Mohammad Abdullatif Bukhari is a Ph.D. candidate in Industrial Organization Engineering at La Universidad Politécnica de Madrid, Spain. The focus of his research has been sustainable reverse logistics network-design and, his dissertation examined, analysed, and designed the reverse logistics networks of post-consumer textile and clothing. In preparation for his dissertation project, Bukhari spent three months as a guest student at Kühne Logistic University in Hamburg, Germany, where he studied the implications of implementing an extended producer-responsibility policy for the textile industry. In recognition of Bukhari's scholastic abilities, the Ministry of Education of Saudi Arabia awarded him scholarships to pursue both his master's and doctoral degrees. He earned his master's degree in civil and mechanical engineering from Widener University, USA (2009) and his bachelor's degree in mechanical engineering from Umm AlQura University, Saudi Arabia (2005). Throughout his distinguished career, Bukhari has worked with leading international organizations in such industries as oil and gas, petrochemicals, and construction. His publications include "Developing a national programme for textiles and clothing recovery" in the Journal of Waste Management \& Research. 